\title{
PACIFIC GAS AND ELECTRIC COMPANY
}

\section{THE GEYSERS POWER PLANT UNIT NO. 3 \\ PLANT DATA}

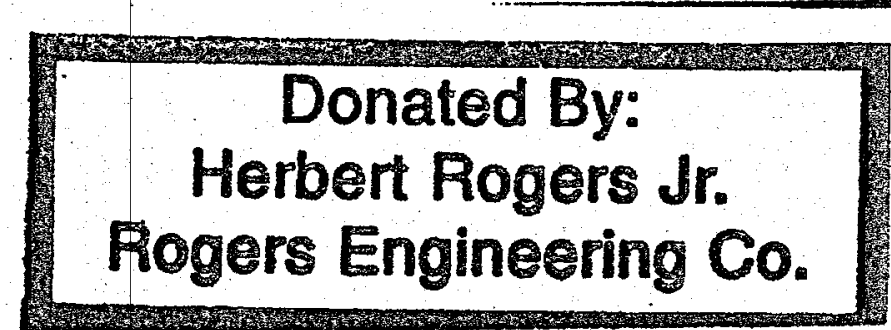




\section{DISCLAIMER}

This report was prepared as an account of work sponsored by an agency of the United States Government. Neither the United States Government nor any agency Thereof, nor any of their employees, makes any warranty, express or implied, or assumes any legal liability or responsibility for the accuracy, completeness, or usefulness of any information, apparatus, product, or process disclosed, or represents that its use would not infringe privately owned rights. Reference herein to any specific commercial product, process, or service by trade name, trademark, manufacturer, or otherwise does not necessarily constitute or imply its endorsement, recommendation, or favoring by the United States Government or any agency thereof. The views and opinions of authors expressed herein do not necessarily state or reflect those of the United States Government or any agency thereof. 


\section{DISCLAIMER}

Portions of this document may be illegible in electronic image products. Images are produced from the best available original document. 


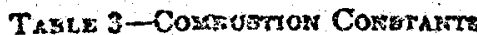

\begin{tabular}{|c|c|c|c|c|c|c|c|c|c|c|c|c|c|c|c|c|c|c|c|c|c|c|c|}
\hline \multirow[b]{3}{*}{ No. } & \multirow[b]{3}{*}{ Substance } & \multirow[b]{3}{*}{ Forriula } & \multirow{3}{*}{$\begin{array}{c}\text { Molocu- } \\
\text { laz } \\
\text { neteitet }\end{array}$} & \multirow{3}{*}{$\begin{array}{l}\text { I.be ner } \\
\text { Cu.Ft. }\end{array}$} & \multirow{3}{*}{ Cu.Ft. } & \multirow{3}{*}{$\begin{array}{l}\text { 9p. Gr. } \\
\text { Air - } \\
1.000^{6}\end{array}$} & \multicolumn{4}{|c|}{ Ileal of Combuntion" } & \multicolumn{6}{|c|}{ Cúrt. Durt. of Combutible } & \multicolumn{6}{|c|}{ Lba. por Lb. of Combuntible } & \multirow{3}{*}{$\begin{array}{l}\text { Expor- } \\
\text { westui } \\
\text { Erros ia } \\
\text { llest of } \\
\text { Combution } \\
\text { ferecrit } \\
+ \text { or - } \\
\end{array}$} \\
\hline & & & & & & & \multicolumn{2}{|c|}{ per Cu.Ft. } & \multicolumn{2}{|c|}{ B.t.u. por LS. } & \multicolumn{3}{|c|}{$\begin{array}{l}\text { Poquired for } \\
\text { Combuntion }\end{array}$} & \multicolumn{3}{|c|}{ Flus Producte } & \multicolumn{3}{|c|}{$\begin{array}{l}\text { Required for } \\
\text { Combuation }\end{array}$} & \multicolumn{3}{|c|}{ Fluo Producte } & \\
\hline & & & & & & & Crass & Note & Grous & Neta & a, & $\mathbf{N}_{\mathbf{2}}$ & Air & $\mathrm{CO}_{2}$ & $\mathrm{Hi}_{2} \mathrm{O}$ & $N_{2}$ & 0 & N, & Air & $\mathrm{cos}$ & $1 \mathrm{H}, \mathrm{O}$ & Pis & \\
\hline $\begin{array}{l}1 \\
2\end{array}$ & $\begin{array}{l}\text { Carbun } \\
\text { Ilydresen }\end{array}$ & $\begin{array}{l}\mathrm{C} \\
\mathrm{C}\end{array}$ & $\begin{array}{r}12.02 \\
2.010\end{array}$ & 0.003327 & 187.723 & 0.00539 & $324.8^{4}$ & $|274.80|$ & $\begin{array}{l}24.093^{\circ} \\
60,943\end{array}$ & $\begin{array}{l}13,093^{\circ} \\
81,005^{\circ}\end{array}$ & 0.8 & $11.28 s$ & 2.382 & $\cdots$ & $\ddot{i .0}$ & $\overline{1 \% 882}$ & $|\overline{2.504}|_{2}$ & $\begin{array}{r}8.353 ! \\
26.100 \%\end{array}$ & 34.344 & $\overline{3.051}$ & $|3.037| 2$ & $\begin{array}{r}5.2633 \\
24.407\end{array}$ & $\begin{array}{l}0.012 \\
0.013\end{array}$ \\
\hline 3 & Orygen & $o_{i}$ & 6.320030 & o cosisi & 11819 & 1.1053 & $\ldots$ & $\cdots$ & $\because$ & $\cdots$ & $\cdots$ & $\cdots$ & $\cdots$ & $\cdots$ & $\cdots$ & $\ldots$ & $\cdots$ & $\cdots$ & $\cdots$ & $\cdots$ & $\cdots$ & $\cdots$ & $\cdots$ \\
\hline 5 & $\begin{array}{l}\text { Nitrogen (atoms.) } \\
\text { Carbis monuside }\end{array}$ & $\begin{array}{l}N_{z} \\
C O\end{array}$ & $\left|\begin{array}{l}28.016 \\
28.01\end{array}\right|$ & $\left|\begin{array}{l}0.07430 \\
0.07104\end{array}\right|$ & $\begin{array}{l}13.413 \\
13.300\end{array}$ & $\begin{array}{l}0.9718^{\circ} \\
0.9472\end{array}$ & $321.0^{A}$ & 321.6 & $\therefore 323$ & $\ldots .323^{i}$ & $\ddot{0.6}$ & i.882 & 2.3s2 & i.o & $\cdots$ & i..820 & $\left|\begin{array}{c}\cdots \\
0.671\end{array}\right|$ & i...00 & 2.47s & $\mid \begin{array}{l}\cdots \\
1.871\end{array}$ & $\ldots$ & $\ddot{1.000} \mid$ & o.ous \\
\hline 6 & Carbon dinxida & $\mathrm{cos}$ & 44.01 & 0.1170 & 8.348 & 1.5282 & $\ldots$ & $\cdots$ & $\therefore$ & $\cdots$ & $\cdots$ & $\cdots$ & $\cdots$ & $\cdots$ & $\cdots$ & $\cdots$ & $\cdots$ & $\therefore$ & $\cdots$ & $\cdots$ & $\cdots$ & $\cdots$ & $\cdots$ \\
\hline 7 & $\begin{array}{l}\text { Paratin neried CnH } \\
\text { Mtethane }\end{array}$ & $\mathrm{CH}_{-}$ & $\ln 042^{2}$ & $\mid 004240^{\circ}$ & $323.532^{\circ}$ & & 1014 on & $|014.5|$ & 23,806 & $21,537^{i}$ & 2.0 & 7.528 & 0.823 & 1.0 & 2.0 & 7.028 & & $|13.275|$ & & & & & 0.033 \\
\hline 8 & Etheno & C,ili & $3006 s^{*}$ & $0.08020^{\circ}$ & $12.453^{\circ}$ & $1 \quad 04882$ & $\left|3783^{n}\right|$ & $18: 36^{\circ}$ & 22,282 & $20.3124^{i}$ & & 13.378 & 16.576 & 2.0 & 3.0 & 13.175 & 3.728 / & 12.394 & 19.118 & 2.027 & 1.723 & 12.394 & 0.030 \\
\hline 0 & Propane & $C_{s} I_{1}$ & $44.094^{k}$ & $\mid 0.1190^{\circ}$ & $8.305^{\circ}$ & $\mid 1.8017^{\circ}$ & $2573^{h}, 1$ & $2373^{\circ}$ & 21.523 & $19,807^{\circ}$ & 5.0 1 & I18.821: & 23.821 & 3.0 & 10 & 18.821 & $3.029^{\prime} 1$ & 12.074 & 18.703 & 2.994 & 1.034 & 12.076 & 0.023 \\
\hline 10 & n-hulase & C.lli: & $38120^{4}$ & $10.1582 \cdot$ & $6.321^{\circ}$ & $2.06854^{\circ}$ & $\mid 3342^{2}-1$ & $31+2^{6}$ & 21,441 & $19.313^{\circ}$ & 0.6 & $24.467 ?$ & 30.907 & 4.0 & 6.0 & 24.487 & $3.678 \mathrm{t}$ & 11.808 & 15.487 & 3.029 & 1.850 & III.00g & 0.022 \\
\hline 11 & Jsobutanse & C.11.0 & BS.120 & $0.1682 \cdot$ & $0.321^{\circ}$ & $2.0 \cos 34^{\circ}$ & $3363 \cdot 1$ & 3103 & 21,257 & 10,829 & & 24.467 & 30.867 & 1.0 & & 24.467 & 3.5701 & 11.008 & 15.487 & 73.020 & $|1.850|$ & $\mid 11.008\}$ & 0.010 \\
\hline 12 & n-Pentaice & $C_{b} H_{n}$ & $72.146^{k}$ & $0.1501^{\circ}$ & $8.252^{\circ}$ & $21872^{\circ}$ & $4200^{4}$ & $39000^{\circ}$ & 22,$0 ; 8$ & $20.485^{\circ}$ & $8.0 !$ & $30.114:$ & 38.114 & 6.0 & 0.0 & 30.114 & 3.848 & 11.808 & 15.353 & 3.050 & 1.198 & 11.805 & 0.028 \\
\hline 13 & Inopentaxe & $c_{a} l_{n}$ & $72.146^{h}$ & $0.1004^{\circ}$ & B. $252^{\circ}$ & $24872^{\circ}$ & 15008 & 3756 & $21,0.92$ & 19.478 & 8.0 & 130.114 & 38.114 & 8.0 & 0.0 & 30.114 & 3.548 & 11.305 & 16.353 & & 1.498 & 11.803 & 0.071 \\
\hline 14 & Nonpertune & $\mathrm{CuH}_{\mathrm{u}}$ & $72.14 e^{k}$ & $0.1904^{*}$ & $8.252^{\circ}$ & $2.4872^{\circ}$ & 3803 & 3503 & 20.970 & 19.396 & 8.0 & 30.114 & 38.114 & 8.0 & 0.0 & 30.114 & 3.648 ' & 11.805 & 18.355 & 33.050 & 1.498 & 11.305 & 0.11 \\
\hline 16 & n-Hexnne & $\mathrm{C}_{\mathrm{H}} \mathrm{u}$ & 80.260 & $0.2274^{\circ}$ & $1.398^{\circ}$ & $2.9701^{\circ}$ & $47 a 2$ & 4412 & 20,040 & 19.403 & 0.3 & 35.760 & 45.280 & 6.0 & 7.0 & 35.760 & 3.628 & 11.738 & 16.200 & 8.054 & 1.806 & 21.738 & 0.08 \\
\hline 16 & $\begin{array}{l}\text { Olefin meries } \mathrm{CnfF}_{\mathrm{zin}} \\
\text { Ethylens }\end{array}$ & Crll. & $28.082^{A}$ & $\mid 0.07123\}$ & $13.470^{\circ}$ & 10.0740 & |1014: & $1514^{i}$ & 21.617 & $20,299^{8}$ & 3.0 & 11.293 & 14.293 & 2.0 & 2.0 & 11.293: & 3.422 & I1 .385 & 16.807 & 73138 & 81,28s & $3|11.385|$ & 0.021 \\
\hline 17 & Propylene & C.H. & $42.078^{k}$ & $0.1110^{\circ}$ & 0.007 & $-12.4500^{\circ}$ & $238 x^{4}$ & $2233^{\circ}$ & 21,404 & $20,115^{i}$ & 4.5 & 16.039 & 21.430 & 3.0 & 3.0 & 10.930 & 3.422 & 11.385 & 14.807 & $7 \mid 3.138$ & $8 \mid 1.285$ & $3 \mid 11.38$ & 0.032 \\
\hline 18 & n-Rutene (Butylsae) & Cille & $60.10+4$ & $0.1480^{\circ}$ & 0.7500 & $.1 .9330^{\circ}$ & $3190^{4}$ & $290100^{6}$ & 21,552 & $20,203^{\circ}$ & 0.0 & 22.585 & 28.585 & 40 & 4.0 & 22.385 & 3.422 & 11.385 & $|14.807|$ & $7 \mid 3.138$ & $8 \mid 1.283$ & 311.385 & 0.031 \\
\hline 19 & leobuticas: & C.110 & $86.104^{k}$ & $0.1480^{\circ}$ & $6: 756^{\circ}$ & $1.9330^{\circ}$ & $3180^{\circ}$ & $24880^{i}$ & 21.484 & $20.135^{\circ}$ & 0.0 & 22.585 & 28.835 & 1.0 & 6.0 & 22.385 & 3.4221 & 11.383 & 11.807 & $7 \mid 3.138$ & 1.233 & 111.385 & 0.031 \\
\hline & n-Penteno & Culfae & $70.130^{4}$ & $0.1852 \cdot 1$ & $8.400^{\circ}$ & $92.1100^{\circ}$ & $1000^{4} \mid$ & $3750^{8}$ & 23.000 & $20,211^{i}$ & 7.6 & $28.232 \mid$ & $\mid 36.732$ & 8.0 & 8.0 & 28.232 & $\left.3.422\right|^{1}$ & 11.385 & 14.867 & $7 \$ .138$ & 81.285 & $8|11.385|$ & 0.037 \\
\hline $\begin{array}{l}21 \\
22 \\
23\end{array}$ & $\begin{array}{l}\text { Arometic serie Cr7tin-o } \\
\text { Besmeno } \\
\text { Toluers } \\
\text { Xyleno }\end{array}$ & 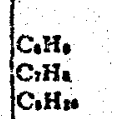 & $\mid \begin{array}{c}78.180^{n} \\
92.134^{n} \\
100,188\end{array}$ & $\left\{\begin{array}{l}0.2060^{\circ} \\
0.2431^{\circ} \\
0.2803^{\circ}\end{array}\right.$ & $\begin{array}{l}4.852^{\circ} \\
1.113^{\circ} \\
3.507^{\circ}\end{array}$ & $\left\{\begin{array}{l}2.0820^{\circ} \\
3.1760^{\circ} \\
3.0818^{\circ}\end{array}\right.$ & $\begin{array}{l}3830^{k} \\
47500^{4} \\
8230\end{array}$ & $\begin{array}{l}3780^{\circ} \\
4550^{\circ} \\
4980^{\circ}\end{array}$ & $\left|\begin{array}{l}18,088 \\
50,537 \\
18,050\end{array}\right|$ & $\mid \begin{array}{l}18,341^{\circ} \\
18,710^{\circ} \\
17,760\end{array}$ & $\mid \begin{array}{c}7.5 \\
2.0 \\
10.8\end{array}$ & $\begin{array}{l}28.232 \\
33.378 \\
30.324\end{array}$ & $\left|\begin{array}{l}33.732 \\
62.878 \\
50.024\end{array}\right|$ & $\begin{array}{l}6.0 \\
7.0 \\
8.0\end{array}$ & $\begin{array}{l}3.0 \\
4.0 \\
5.0\end{array}$ & $\begin{array}{l}28.232 \\
33.878 \\
39.824\end{array}$ & $\begin{array}{l}3.073 ! 1 \\
3.126 ! \\
3.1051\end{array}$ & $\begin{array}{l}10.224 \\
10.401 \\
10.330\end{array}$ & $\begin{array}{l}13.297 \\
13.627 \\
13.093\end{array}$ & $\begin{array}{l}7 / 3.381 \\
7 / 3.364 \\
3.317\end{array}$ & $\begin{array}{l}10.602 \\
0.783 \\
0.859\end{array}$ & $\begin{array}{l}10.228 \\
30.401 \\
10.530\end{array}$ & $\begin{array}{l}0.12 \\
0.22 \\
0.36\end{array}$ \\
\hline & Miwrellanoous gkent & & & & & & & & & & & & & & & & & & & & & & \\
\hline $2 i$ & Acetylents & Calli & 26.036 & 0.00071 & 14.346 & b.0107 & 1488 & $\mid 14.38^{i}$ & 21.344 & $20,417^{6}$ & $\begin{array}{l}2.8 \\
12.0\end{array}$ & $\left|\begin{array}{r}0.411 \\
03.470\end{array}\right|$ & $\mid 11.811$ & $\begin{array}{r}2.0 \\
10.0\end{array}$ & 1.0 & $\mid \begin{array}{c}0.611 \\
55.170\end{array}$ & $\mid \begin{array}{l}3.073 \\
2.003\end{array}$ & 10.224 & $\begin{array}{l}13.207 \\
12.83 t\end{array}$ & 73.281 & $\begin{array}{l}10.892 \\
40.652\end{array}$ & 210.224 & 0.13 \\
\hline $\begin{array}{l}25 \\
28\end{array}$ & $\begin{array}{l}\text { Naphobmless } \\
\text { Methy! alertho! }\end{array}$ & $\begin{array}{l}\text { Conllo } \\
\mathrm{CH}, \mathrm{OS}\end{array}$ & $\begin{array}{r}128.102 \\
32.041\end{array}$ & $0.334^{\circ}$ & $\begin{array}{r}2.935^{\circ} \\
11.820^{\circ}\end{array}$ & $\cdot \begin{array}{l}4.4208^{\circ} \\
1.1052^{\circ}\end{array}$ & $\left|\begin{array}{c}6854 \\
807.0\end{array}\right|$ & {$\left[\begin{array}{c}5654 \\
768.0\end{array}\right.$} & $\left|\begin{array}{l}17,228 \\
10,259\end{array}\right|$ & $\begin{array}{c}18,708 \\
9078\end{array}$ & $\left|\begin{array}{l}22.0 \\
1.8\end{array}\right|$ & $\left|\begin{array}{l}0.610 \\
8.61\end{array}\right|$ & 7.146 & 1.0 & 2.0 & $5.640 \mid$ & $\mid i .103$ & $4.08 t$ & $\left|\begin{array}{ll}6 & 4\end{array}\right|$ & i. & 1.525 & 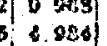 & $\ddot{0}$ \\
\hline 27 & Etbyl wicohol & C.ll.OH & $\$ 6.067$ & $70.1210^{\circ}$ & $8.2210^{\circ}$ & $11.8800^{\circ}$ & 2000.3 & 1450.5 & 13,101 & 11,020 & 3.0 & $|11.203|$ & $\mid 14.203$ & 20 & 3.0 & 11.203 & 2.084 & 0.034 & 0.018 & 81.022 & 2,1170 & 0.034 & 0.000 \\
\hline 28 & Amasunis & Nil. & 17.031 & o.0485" & $21.014^{\circ}$ & $0.8001^{\circ}$ & $1+1,1$ & 393,1 & 2048 & coor & 0.75 & 2,323 & $\mid 3.873$ & $\cdots$ & 1.6 & 3.323 & $\mid 3.800$ & +.088 & 6.007 & $7 \mid \ddot{g o}_{3}$ & 8.887 & 0.314 & 0.028 \\
\hline & Bullur & & 32.05 & & & & $\cdots$ & $\cdots$ & 3083 & 3083 & $\ldots$ & $\cdots$. & $\cdots$ & $\ddot{a}$ & $\cdots$ & & (0.9e3) & $3.3 B$ & 4.285 & 17.098 & $\ldots$ & 8.287 & 3.821 \\
\hline $\begin{array}{l}29 \\
30\end{array}$ & Nydregen sulfide & $\mathrm{F}, \mathrm{B}$ & 34.076 & $50.02109 \%$ & of $20.070^{\circ}$ & $-11.1898^{\circ}$ & 847 & $\operatorname{sos}$ & 7100 & 6348 & 1.0 & 6.040 & $7.14 \pi$ & $\begin{array}{l}\mathrm{BO} \\
1.0\end{array}$ & 1.0 & 6.080 & 1.000 & 4.058 & 8.007 & $7 \begin{array}{c}80 \\
1.880\end{array}$ & 00.530 & 4.58 & -0.20 \\
\hline 31 & Butluz dioside & 50 & 4.00 & 0.1233 & 8.770 & 2.204 & $\ldots$ & $\ldots$ & $\ldots$ & $\ldots$ & $\ldots$ & $\ldots$ & $\ldots$ & $\ldots$ & $\ldots$ & $\ldots$. & $\ldots$ & $\ldots$ & $\ldots$ & $\ldots$ & $\ldots$ & $\ldots$ & ... \\
\hline 32 & Fisier rapot & $\mathrm{H}_{5} \mathrm{O}$ & 18.018 & 0.047580 & o $21.017 \circ$ & $0.0210^{\circ}$ & $\ldots$ & .. & & $\ldots$ & $\ldots$ & & $\ldots$ & $\ldots$ & $\ldots$ & $\ldots$ & $\ldots$ & $\ldots$ & $\ldots$ & $\ldots$ & $\ldots$ & $\ldots$ & $\cdots$ \\
\hline 33 & Air & 1 & 28.0 & 0.07058 & 13.083 & $i_{1} .0000$ & $\ldots$ & $\ldots$ & & $\ldots$ & & & 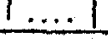 & r. & $\ldots$ & -1 & & . & & 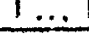 & $\rightarrow$ & $\cdots$ & $\cdots$ \\
\hline & 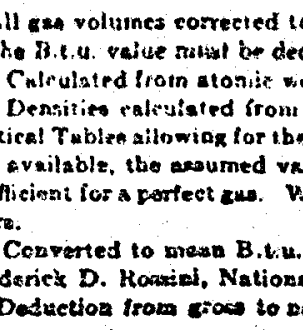 & 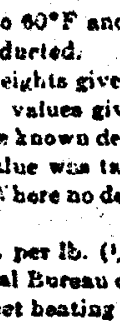 & 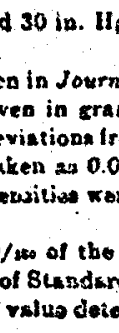 & 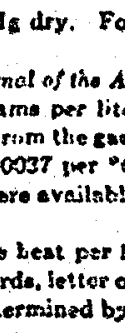 & 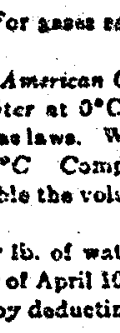 & 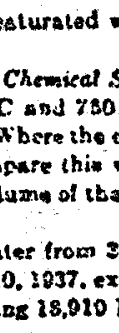 & $\begin{array}{l}\mathrm{mm} \text { in } \\
\text { coefficient } \\
\text { with o. } \\
\text { smols wa }\end{array}$ & 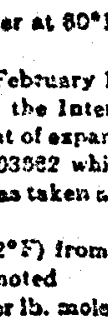 & 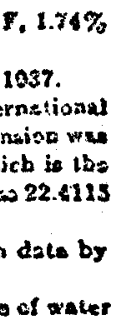 & & 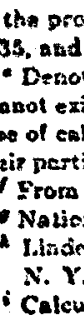 & 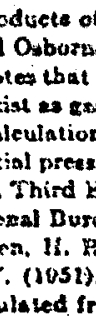 & 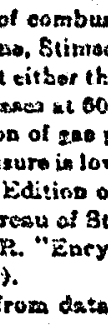 & 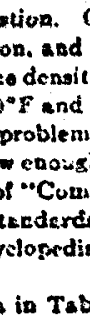 & 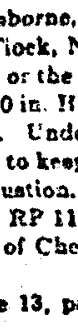 & 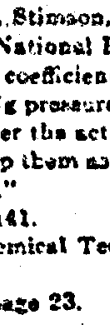 & 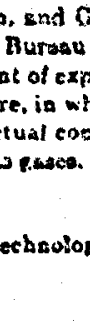 & $\begin{array}{l}\text { Cingine } \\
\text { uof olat } \\
\text { ponasion } \\
\text { hich cas } \\
\text { pocontra } \\
\text { 2. } \\
\text { ozy." Vo }\end{array}$ & 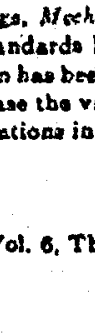 & 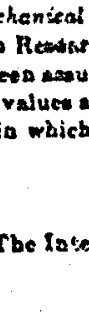 & 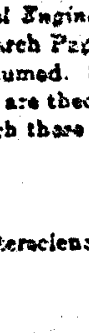 & 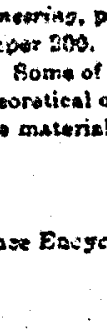 & 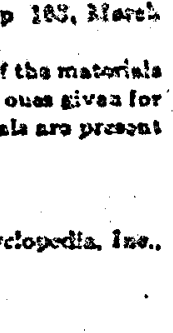 \\
\hline & $\ldots$ & & & & & & & & & & & & & & & & & & & & & & \\
\hline
\end{tabular}




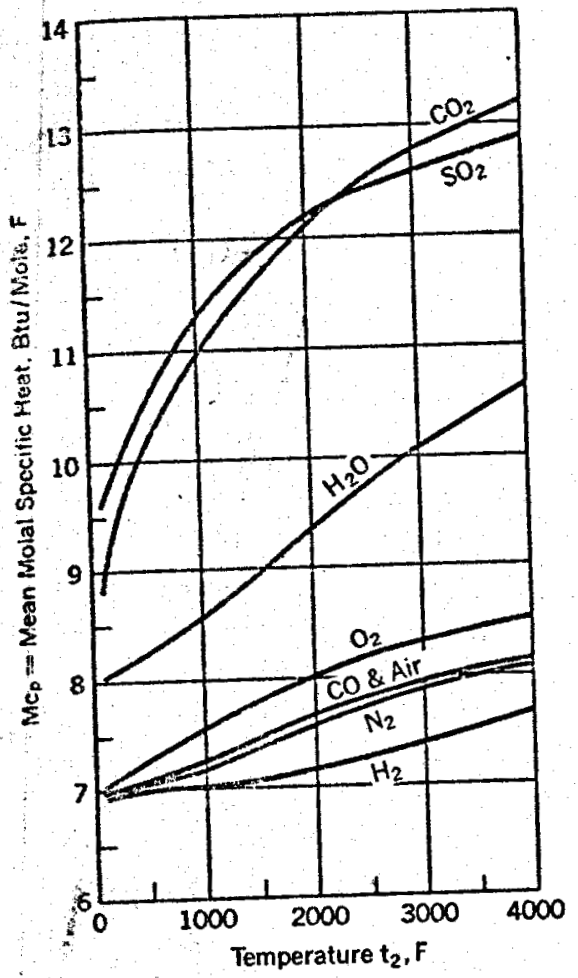

Fig. 2 Mean molal specific heat of gases between final temperature $\left(t_{2}\right)$ and $80 F$ at standard atmospheric pressure.

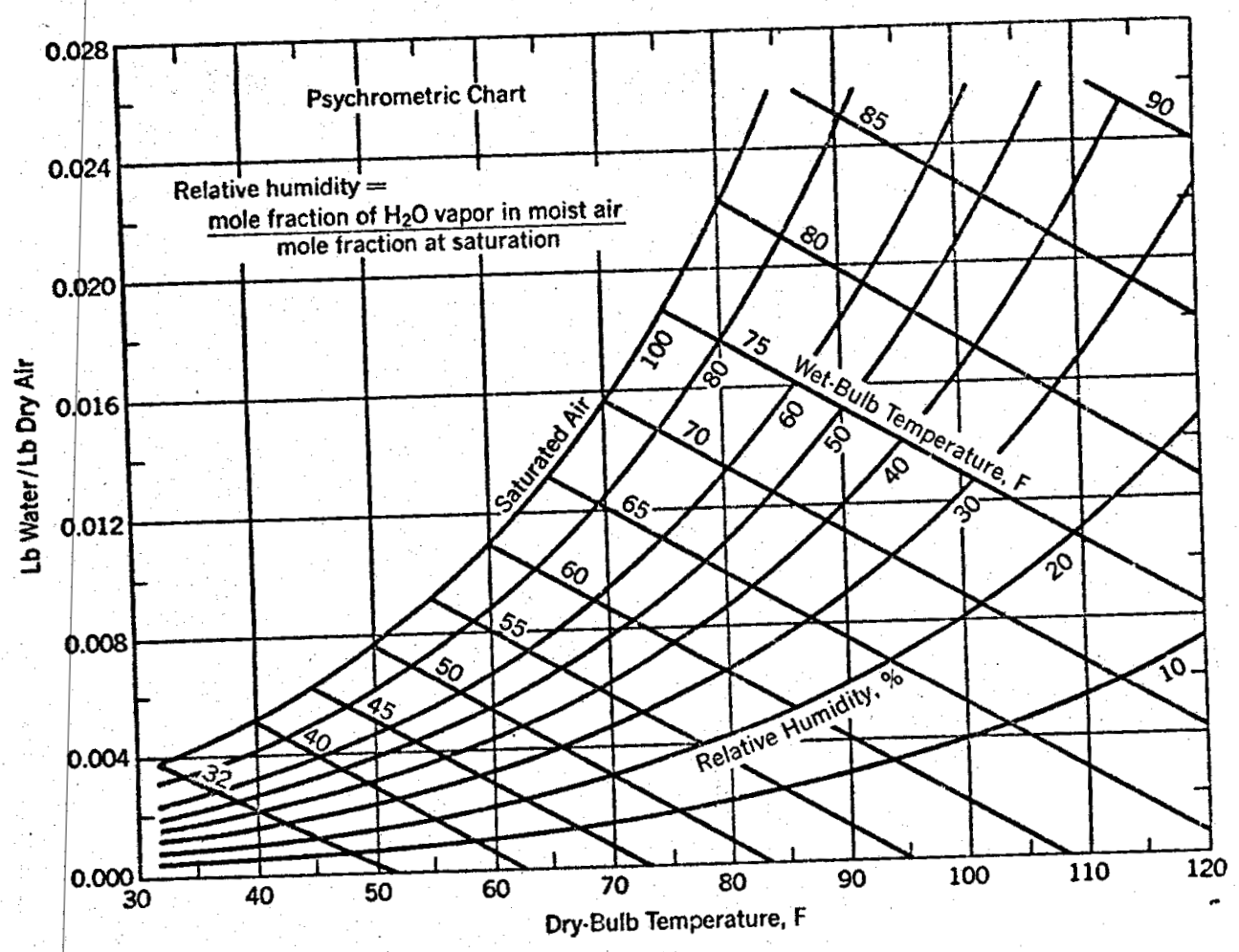

Fig. 3 Water content of air for various wet- and dry-bulb temperatures.

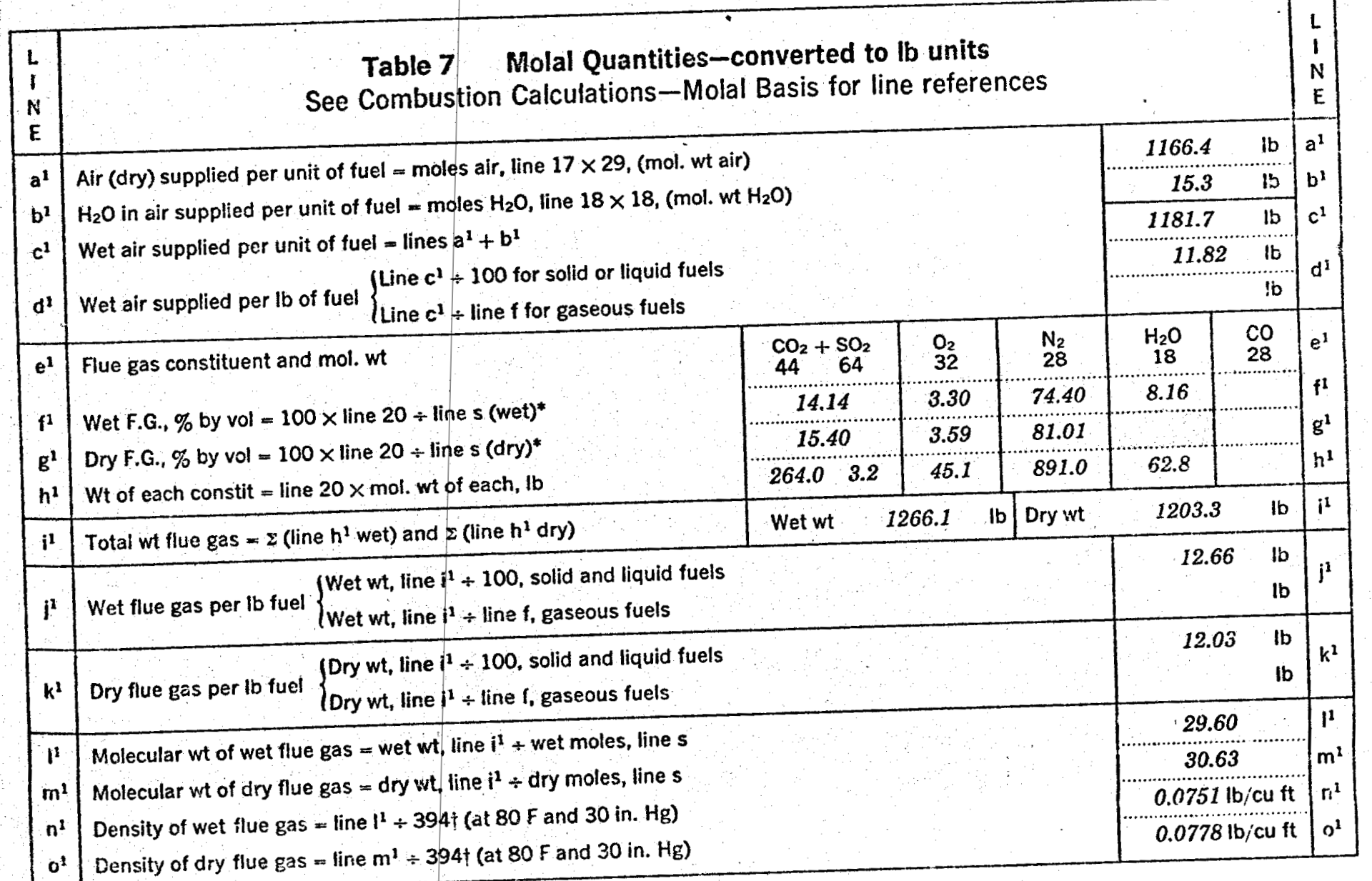

a based on total air, line d, assigned or observed.

alysis as calculated, bast $\mathrm{G}$ on total air, line d, assign ORSAT analysis when flue gas is analyzed.

The calcstated values, line 8 , should agree substantially $\mathrm{kH}$. 




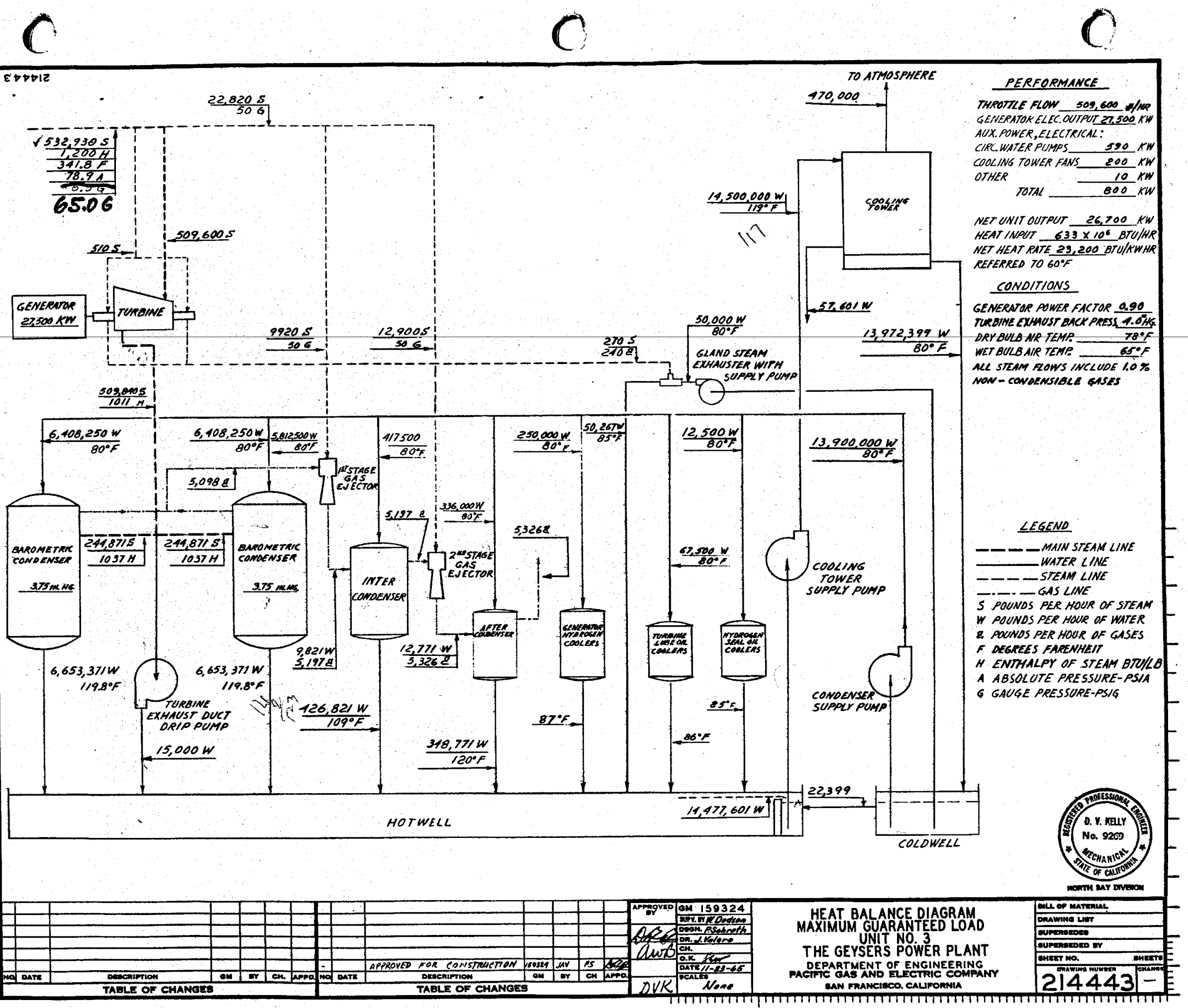




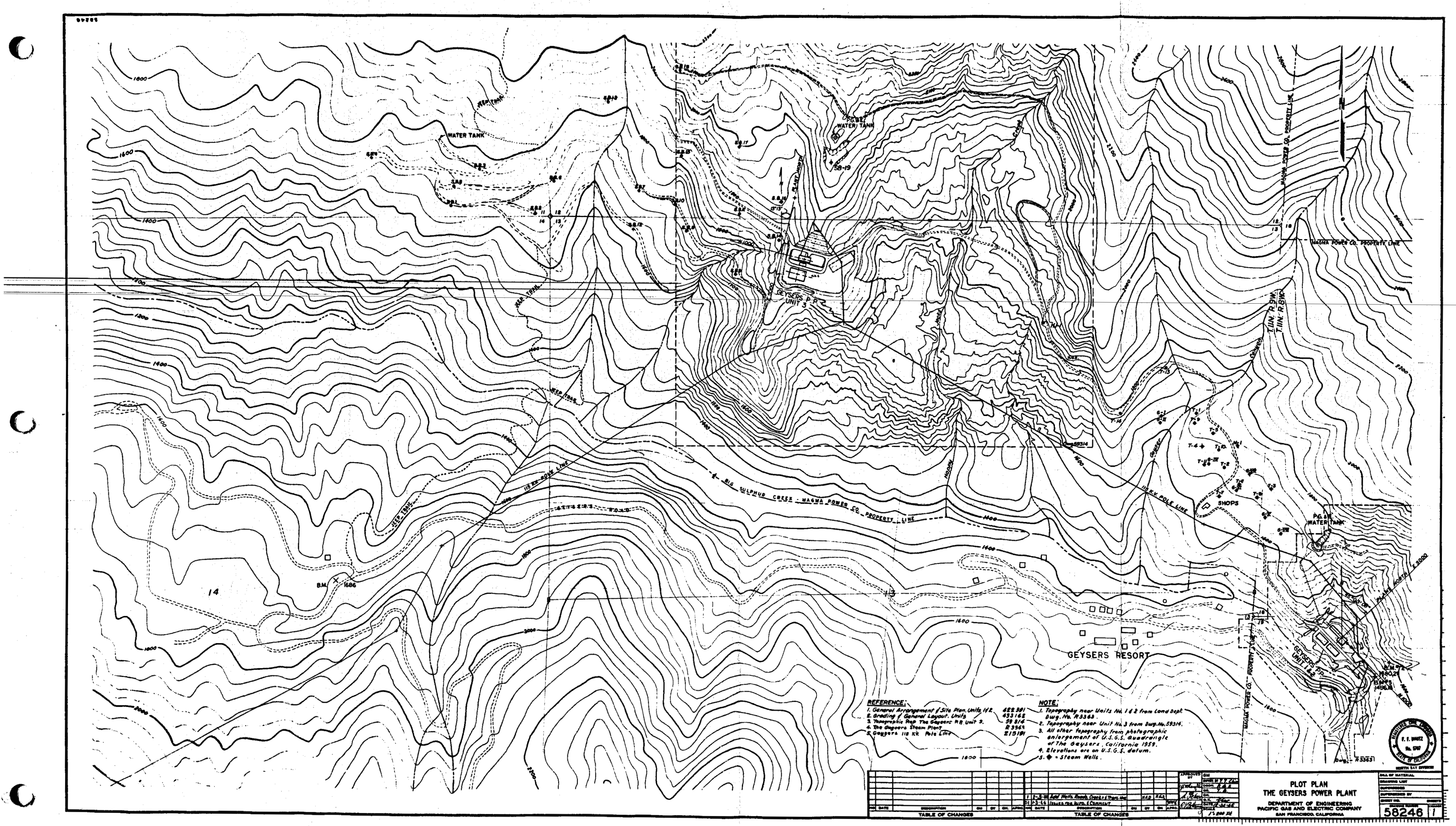




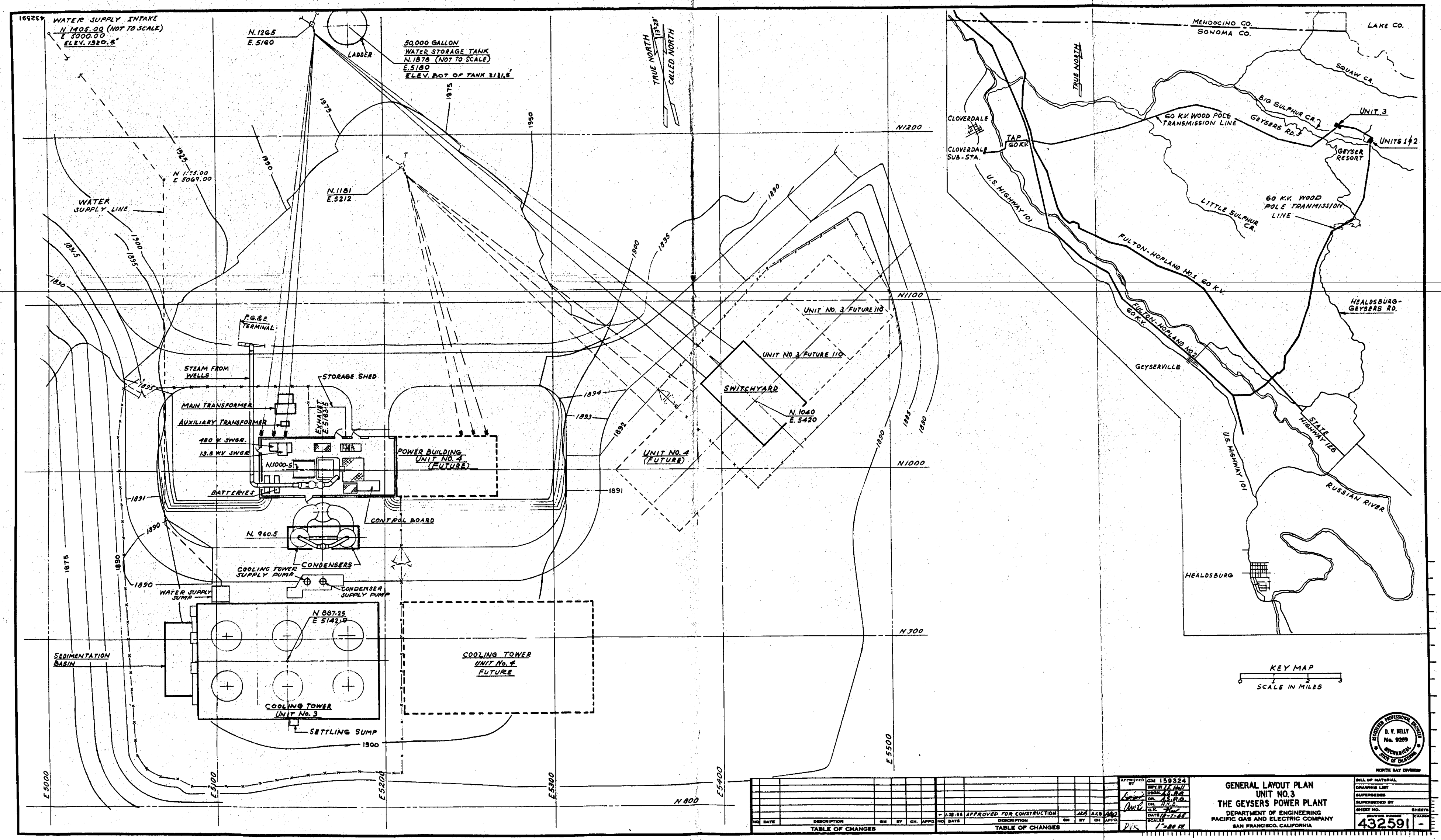




\section{TURBINE-GENERATOR}

TURBINE

Manufacturer

Purchase Order Number

Serial Number

Size

Type

Kilowatt Rating

Rated Speed

Critical Speed

Steam Pressure

Steam Temperature

Exhaust-Vacuum

Approximate Weight-Turbine

Approximate Weight-Rotor
Elliott Division of Carrier Corp.

LR 34093

$\mathrm{B}-4908$

NB-7

Horizontal shaft, 7-stage, condensing

27,500

$3,600 \mathrm{rpm}$

$2,366 \mathrm{rpm}$

78.9 psia

$341.8 \mathrm{~F}$

4 in. $\mathrm{Hg}$ abs

$120,0001 \mathrm{~b}$

$11,500 \mathrm{lb}$

GENERATOR

KVA

KW

P.F.

Hydrogen

Volts

Amp.

Freg.

Fld. Volts

FId. Amp.

stator Wt.

Rotor Wt.
32,000

28,000

0.90

30 psig

13,800

1,340

$60 \mathrm{cps}$

250

450

$115,000 \mathrm{lb}$

$30,0001 \mathrm{~b}$ 


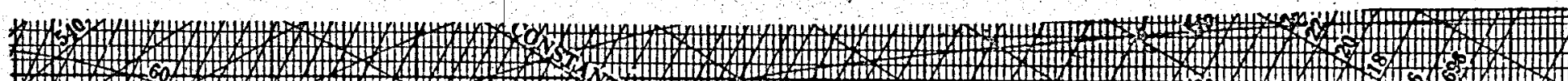
(1)

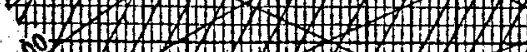

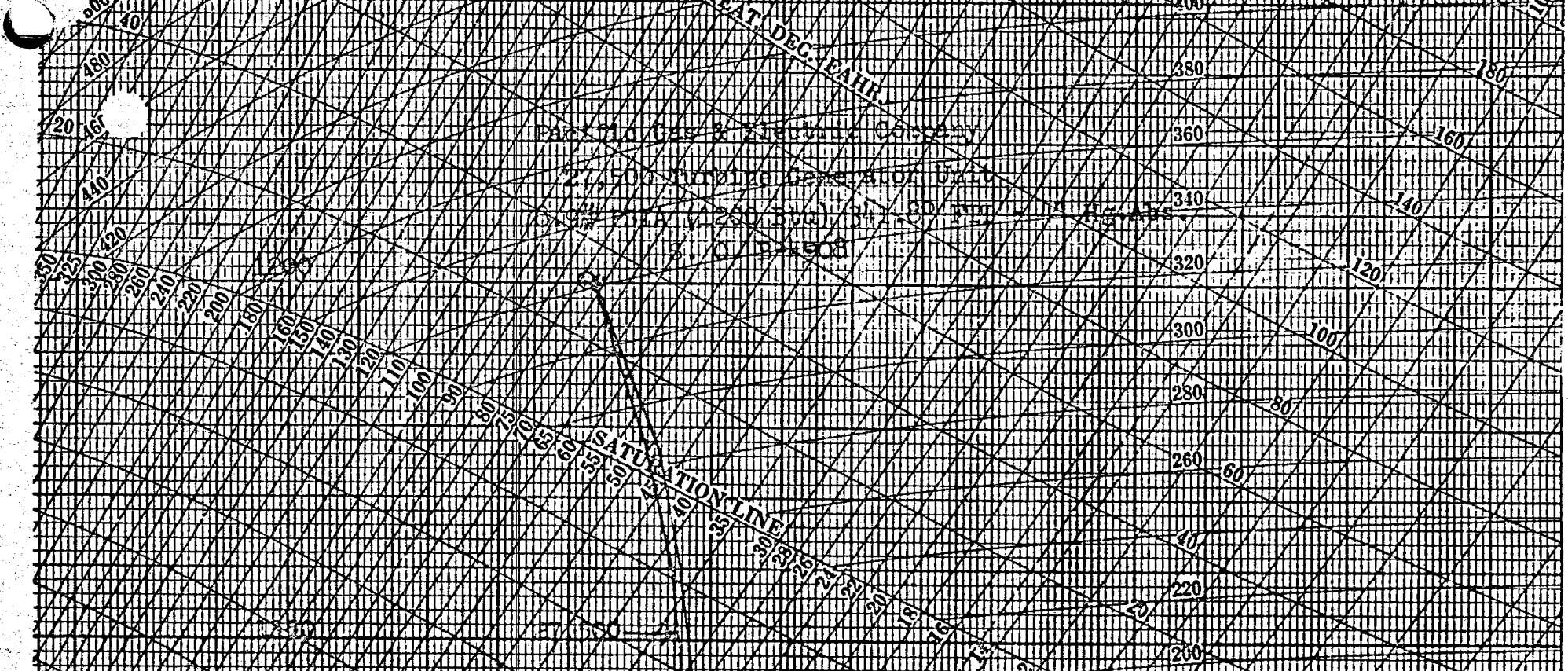

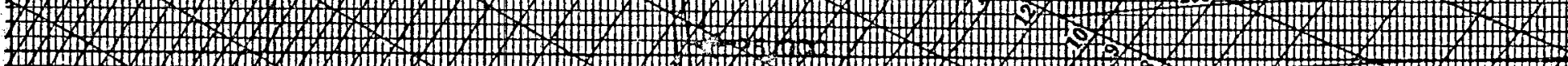
(

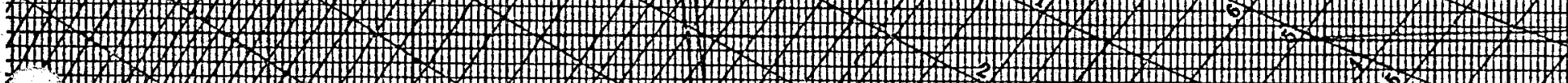

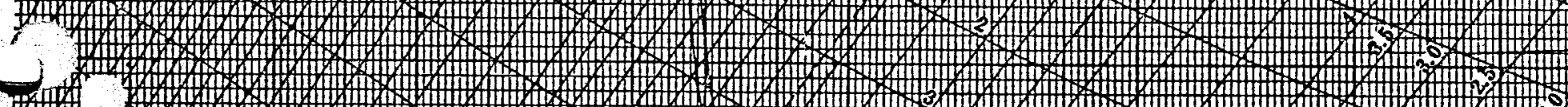

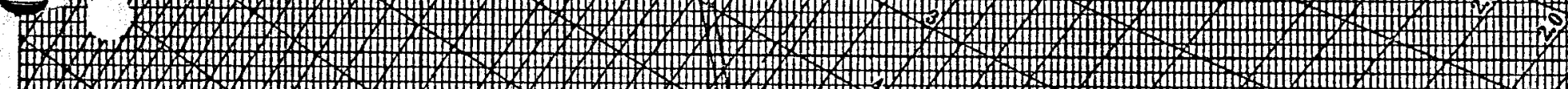

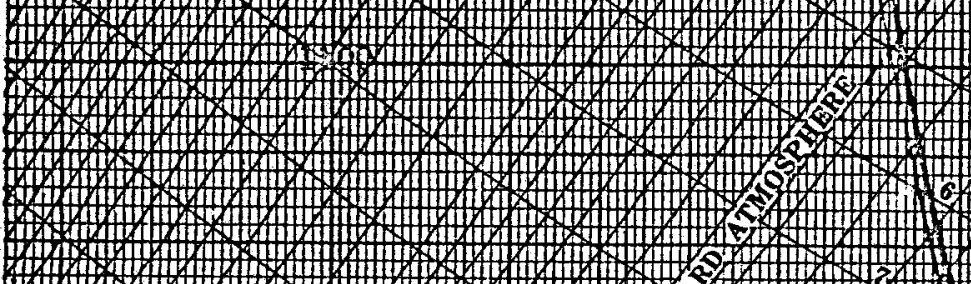

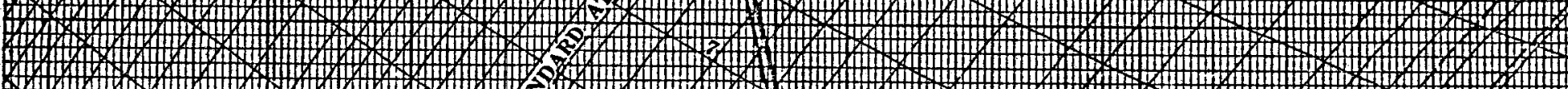
(W (๐)

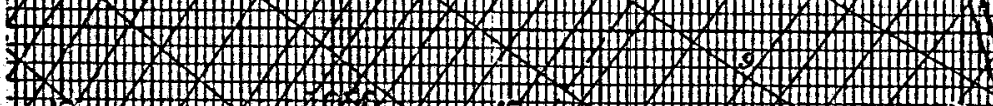

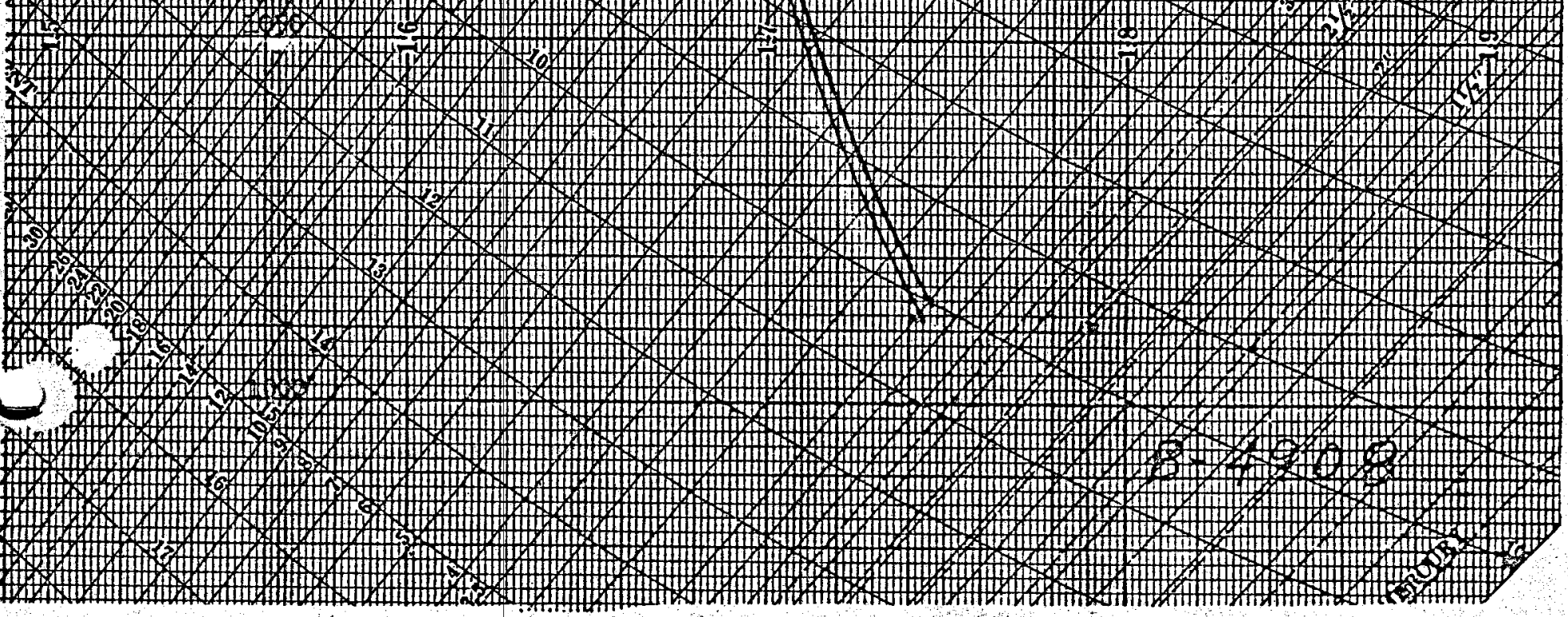


REF. NO

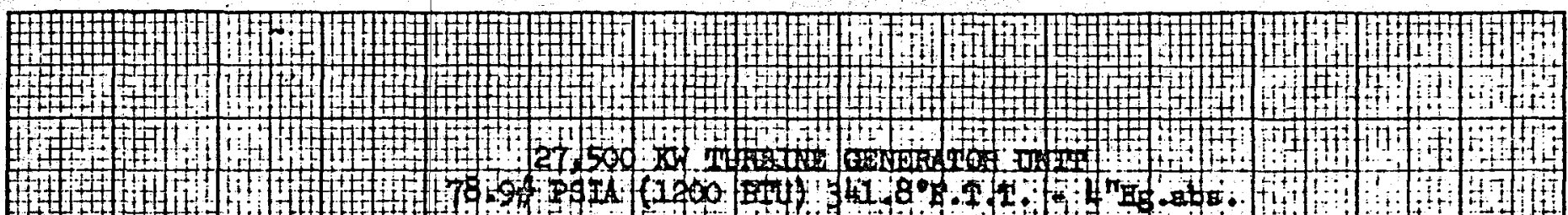

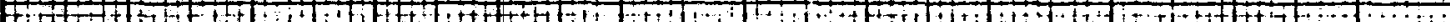

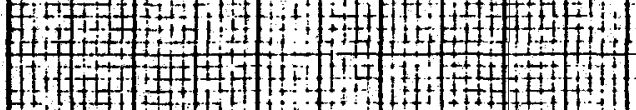

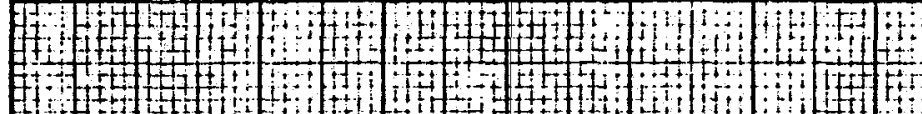

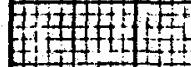

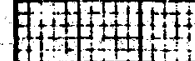

C

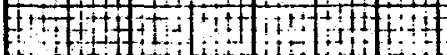

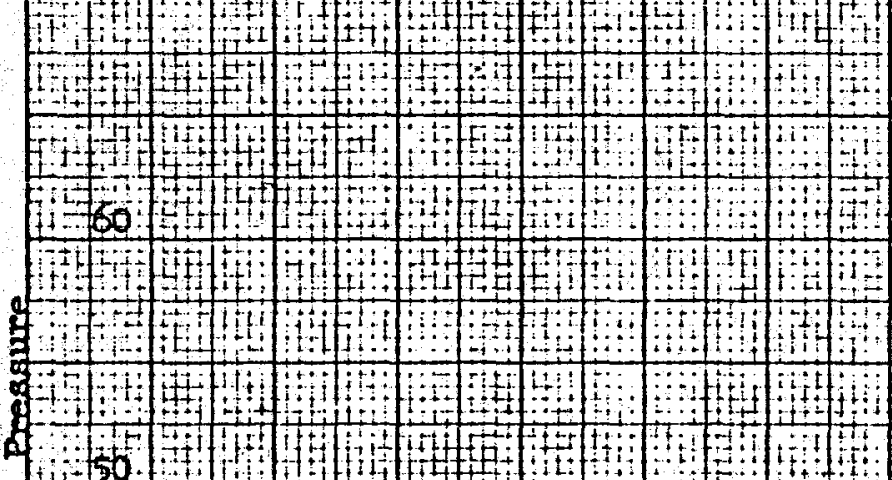

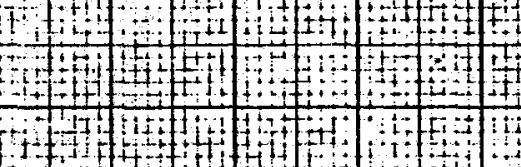



int

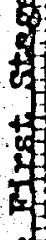
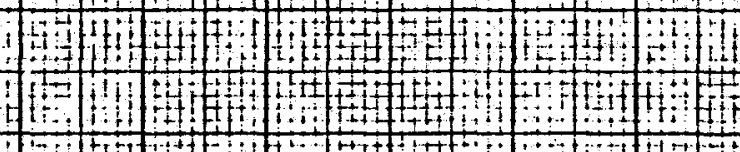

40
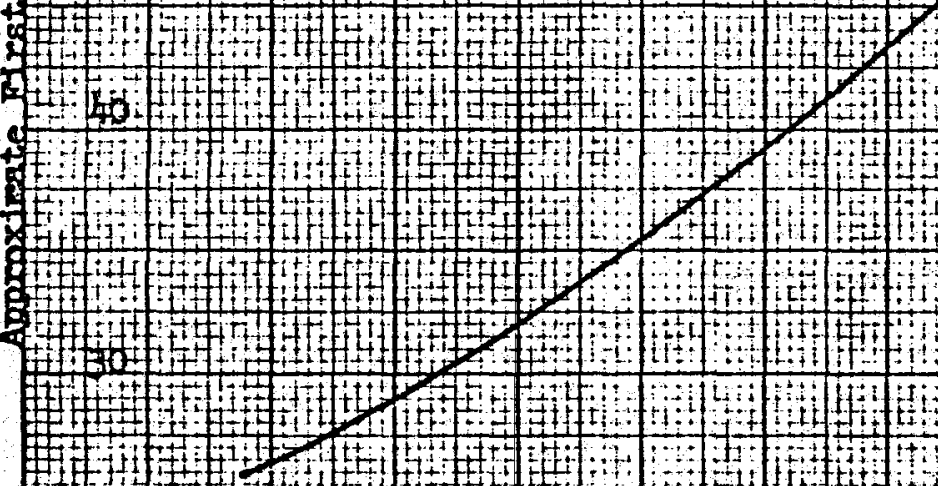

1.

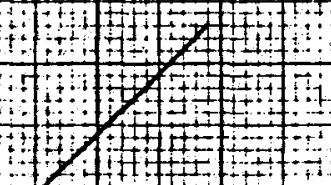

(19)

infition

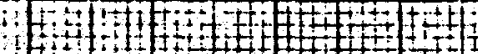

f



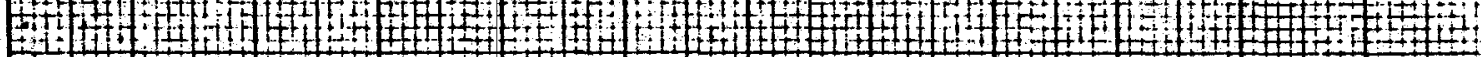

Itr

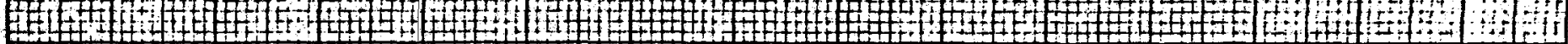

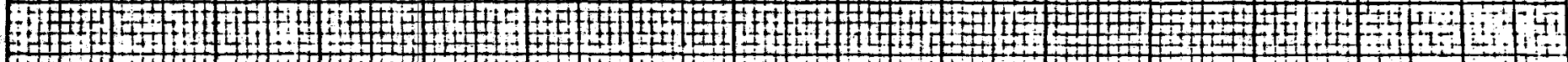

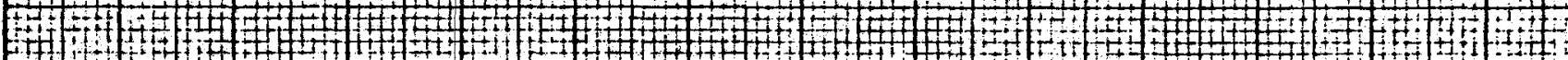

20

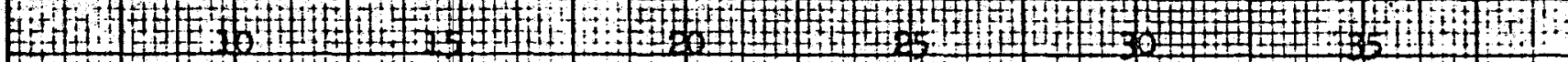




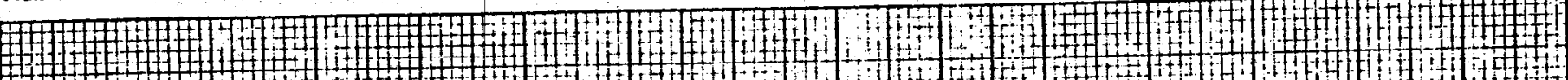

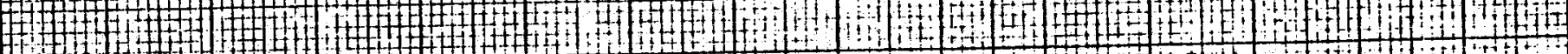

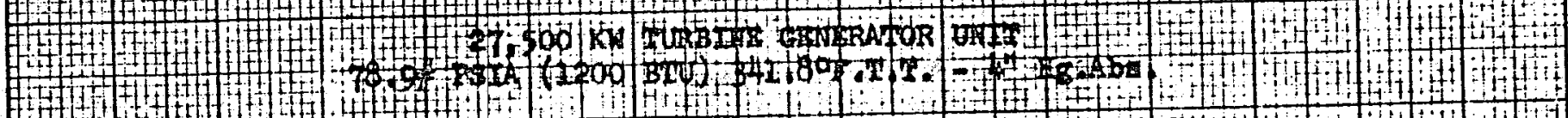

G

it

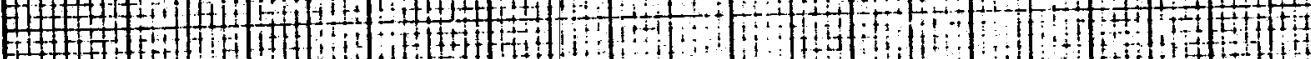

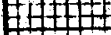

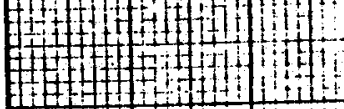

tiftetitis

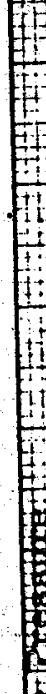
$+4+4$

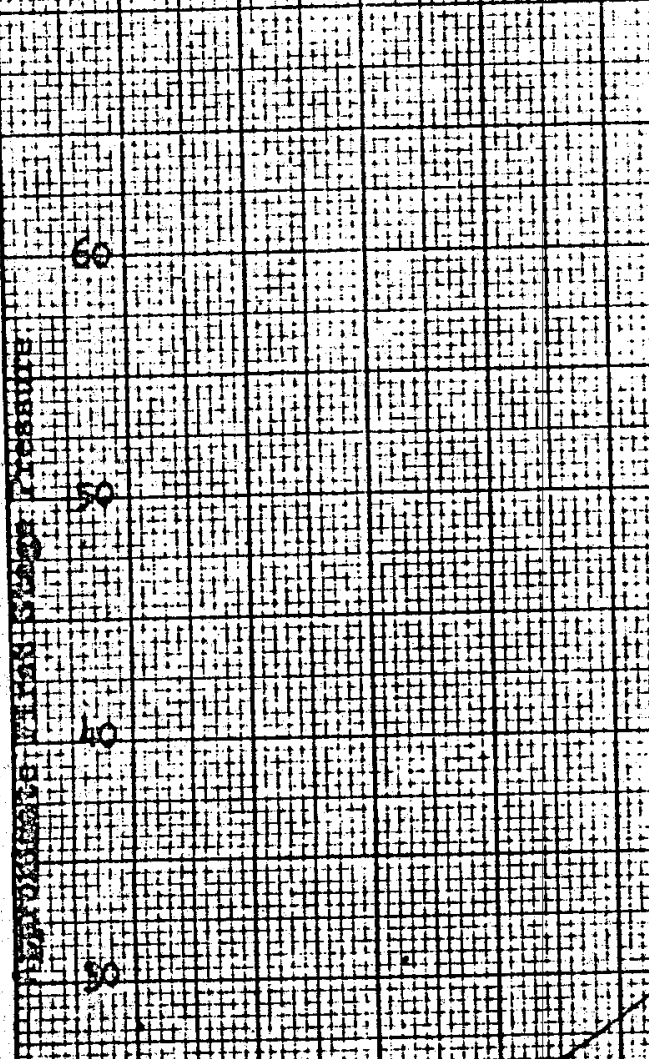
(F)

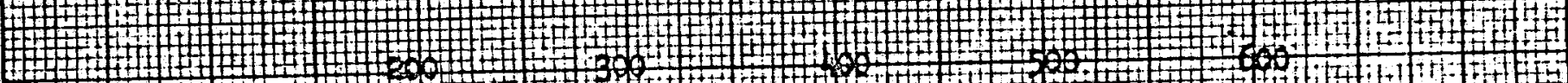

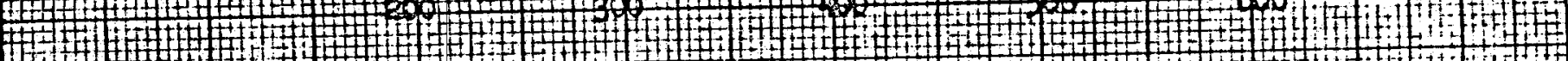

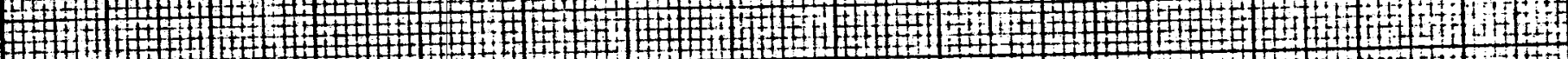

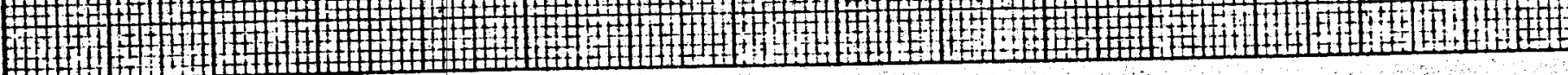




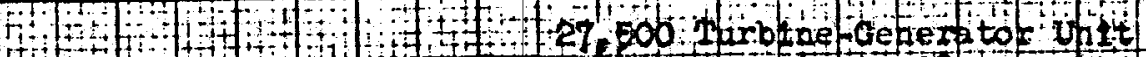

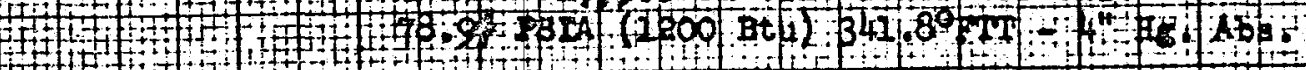

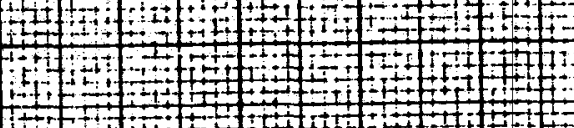

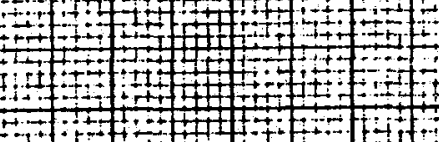

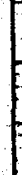

눈

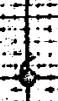

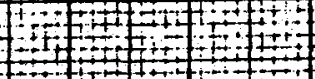
-

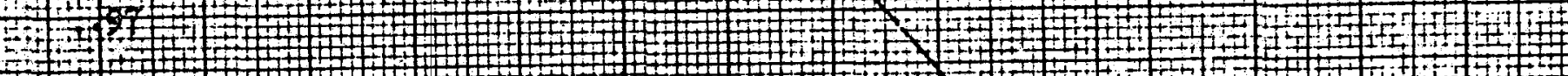

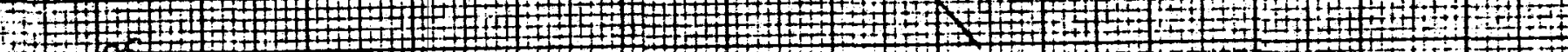

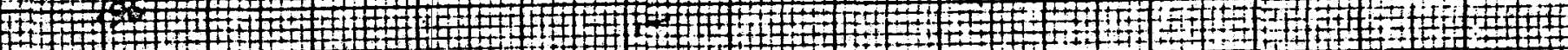

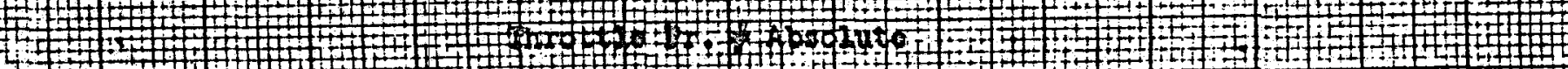
$4+27+27$

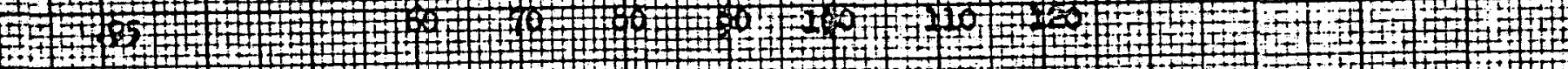

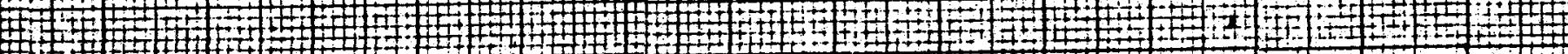

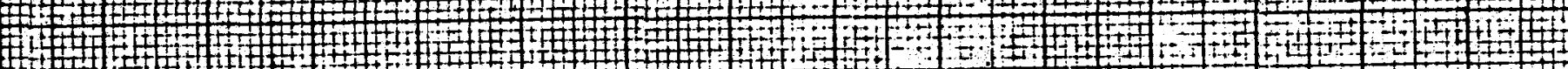

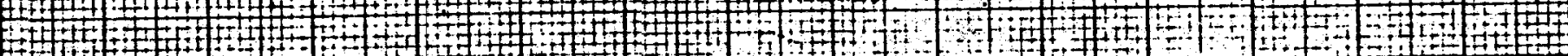


REF, NO. TITLE PACIFIC GAS AND ELECTRIC COMPANY

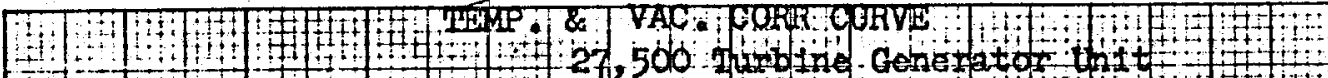

No. $\quad B-4908-2$

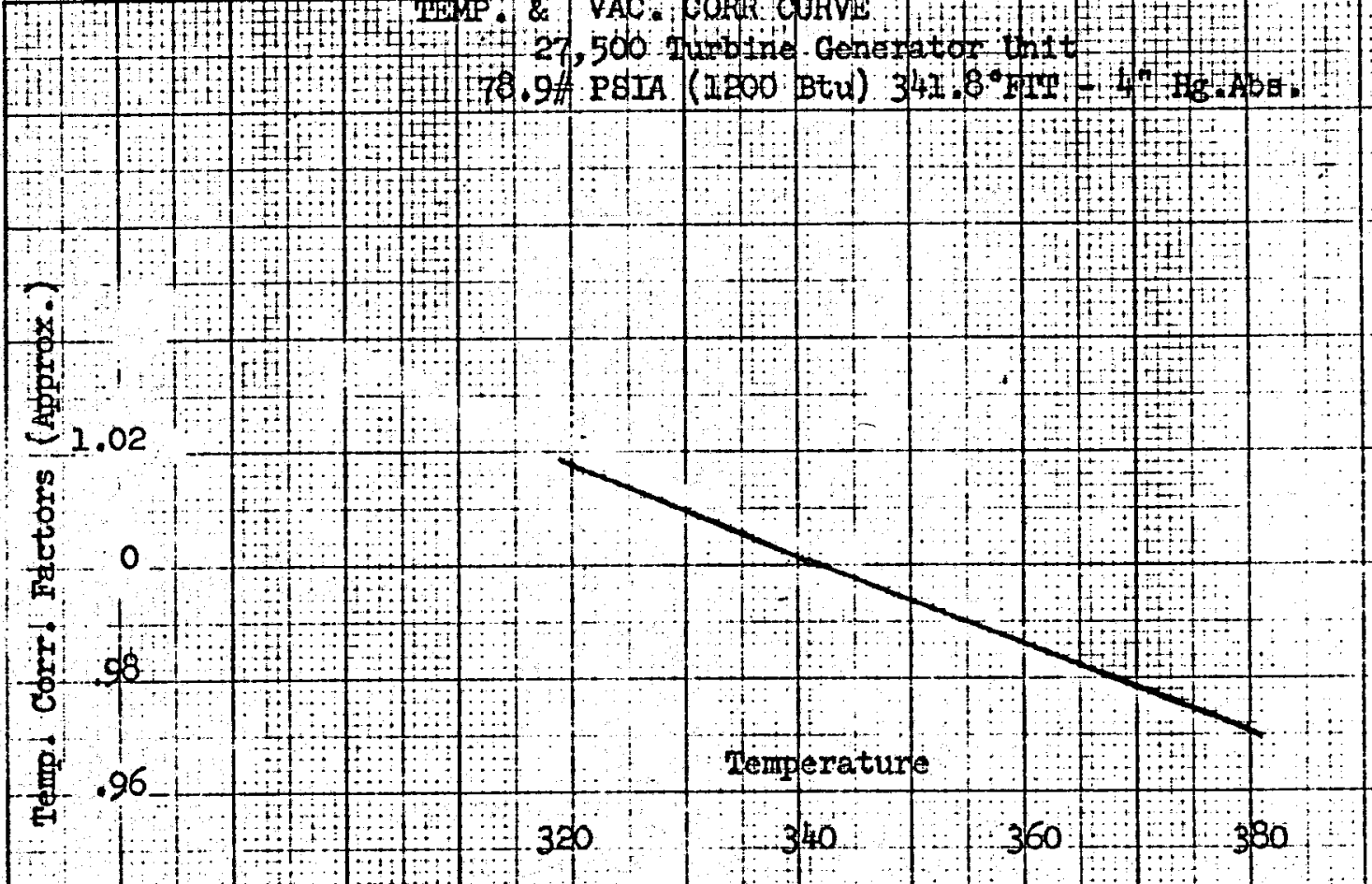

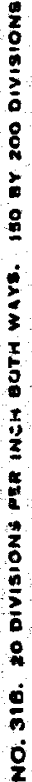

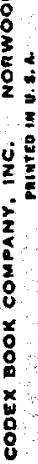

(1...

1.13

1)/2

1.08

6.04

5.00

at:

47412
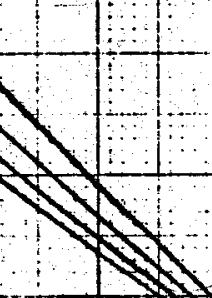

-

66

8

0,1

$\frac{g}{y}-\frac{92}{1}$

ख 88

苟

a $\quad 84$ : $\quad 0$ :

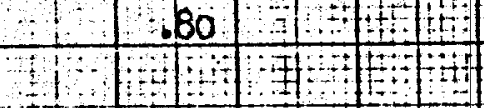

1101 क H

5

$12+40(25,000 \mathrm{gW})$

$10+1$

$\frac{1}{4}$

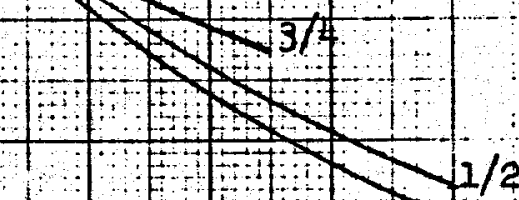

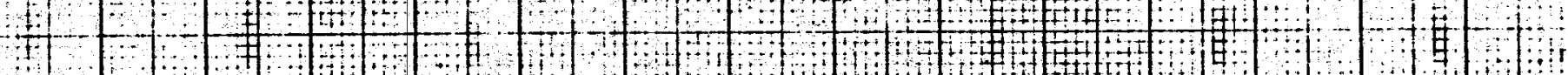




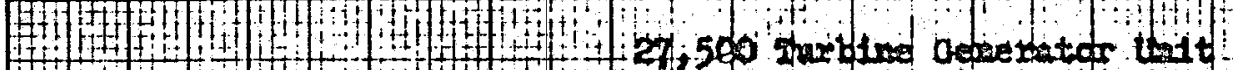

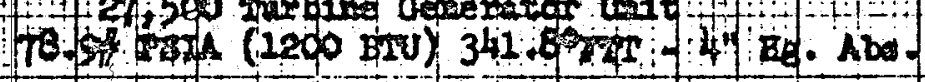

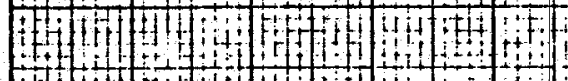

(1)

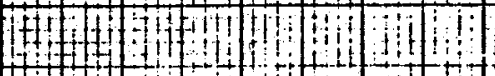

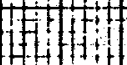

Hititi:

$4+1+10$

$+40$

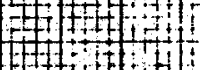



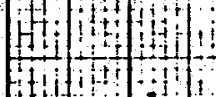

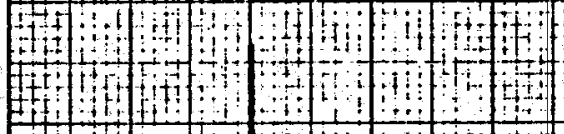



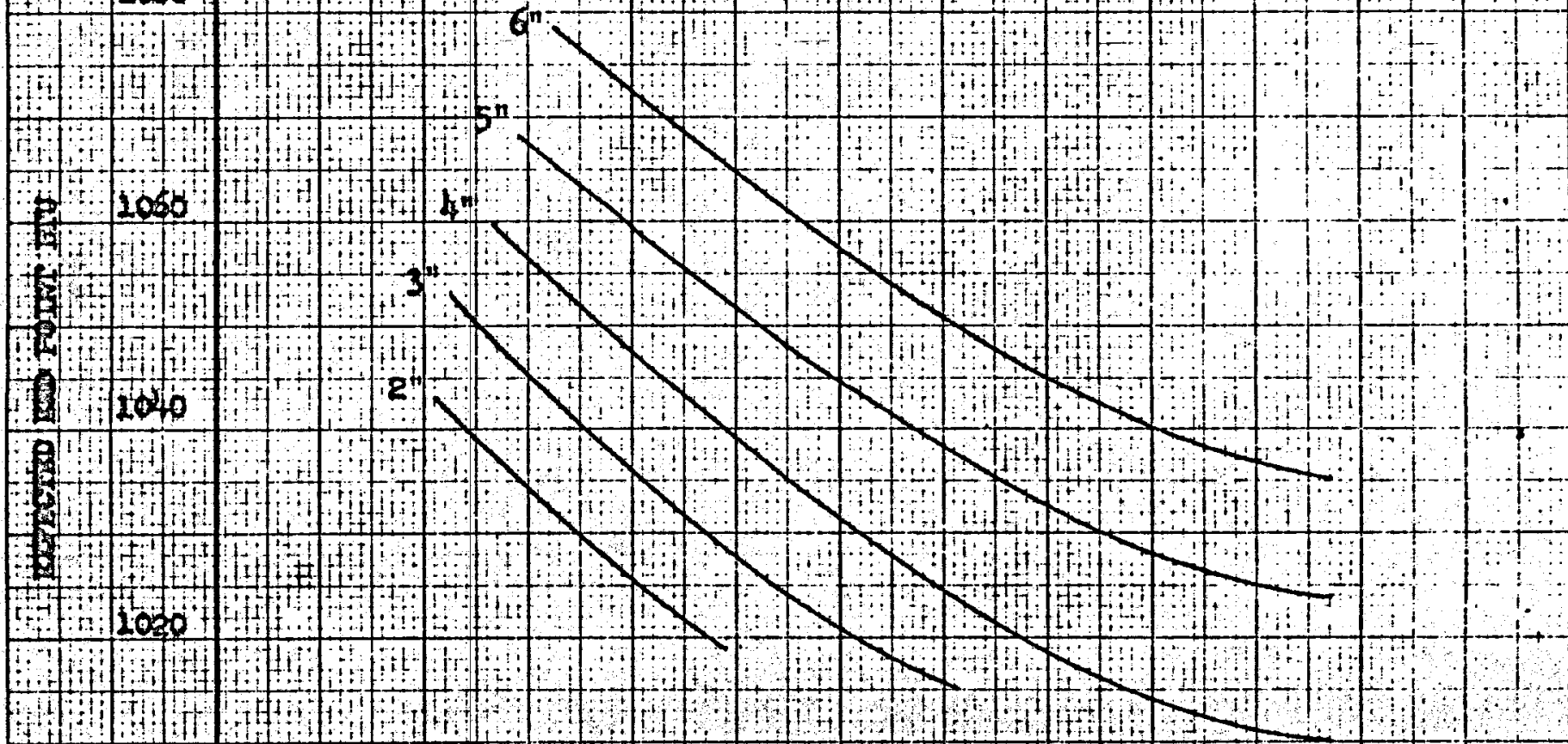

7010 .

$13+2000$

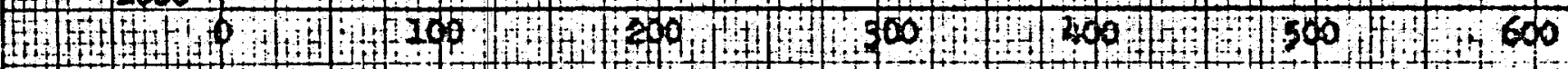

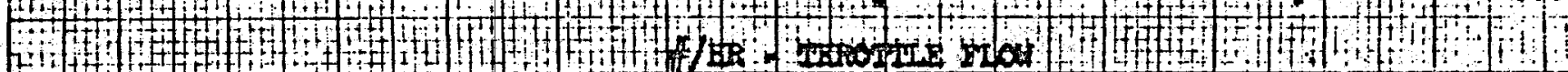

(1:

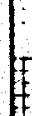

(1)

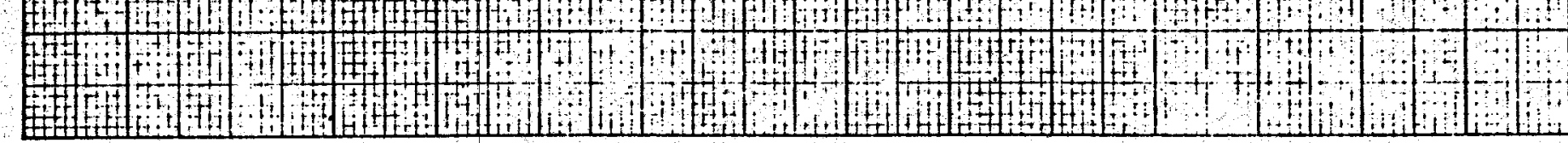


FORM 1107-318

REF. NO.

TITLE PACIFIC GAS AND ELECTRIC COMPANY
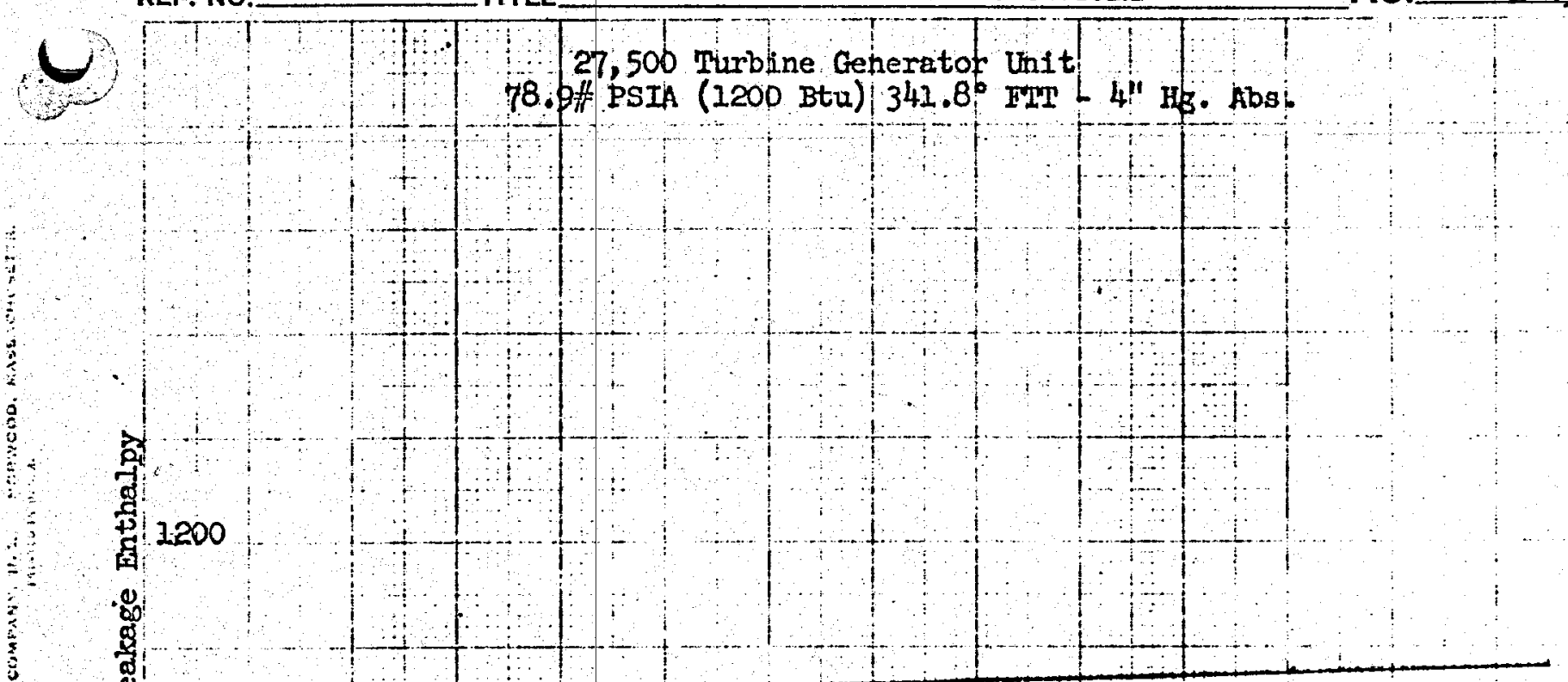

27, 500 Turbline Geheratof Unit

78.9 \# PSIA (1200 Btu) $341.8^{\circ}$ ITI L 4!" H3. Abs

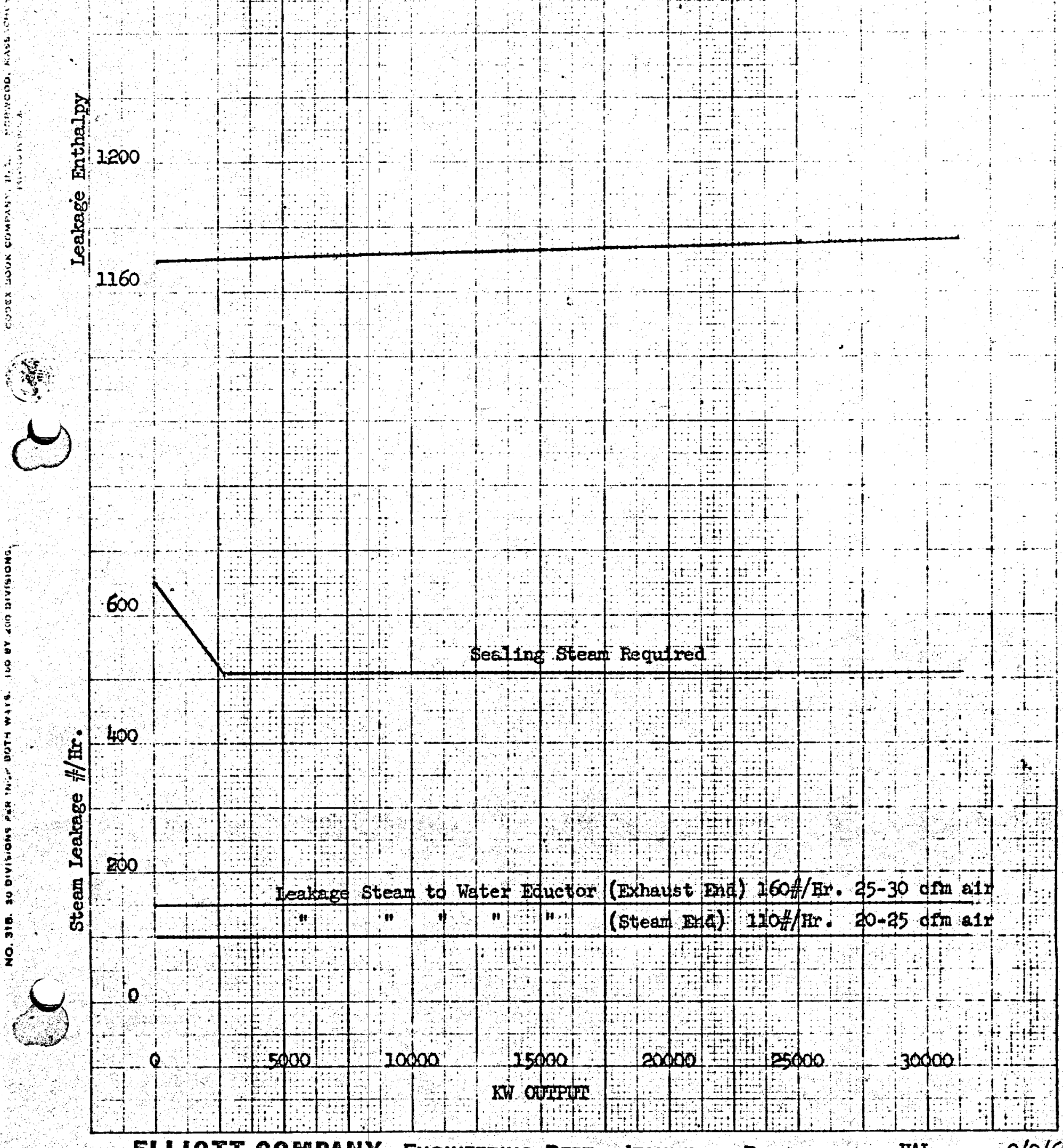


ROUGH DRAFT

$(2 / 4766)$

TURBINE EXFIIUST DUCT AND DRIP PUMPS

\section{GENERAL DESCRIPTION}

The turbine exhaust duct carries exhaust steam from the turbine to the barometric condensers. Design and construction of the duct is in accordance with the ASME Boiler and Pressure Vessel Code, Section VIII, 1962. The materials of the duct are stainless steel.

Steam leaves the turbine exhaust hood travelling vertically downward. A duct elbow and a transition section turn the flow to horizontal and conduct the steam to a duct tee section. The tee section is of vertical cylindrical form; it conducts steam upward to a wye. The steam flow is divided at the wye, half the steam is conducted to each of two barometric condensers via two elbows. The steam enters the condensers through their sides, near the bottoms.

The tee section of the duct has two expansion joints near its top, and one expansion joint near the bottom, above the dished head bottom. . It is restrained from excessive vibration by a system of vibration snubbers which have flexible ball type stub joints at each end.

The dished head on the bottom of the duct tee section will collect any liquid condensed from the steam travelling through the duct. Two exhaust duct drip pumps are provided to remove excess water from the duct. As accumulation of an excessive amount of water in the duct could cause damage to the turbine, a high liquid level trip (HLT-1) and a backup high liquid level trip (HIT-2) are provided, either of which will actuate the turbine lockout relay. In adition, the turbine lockout relay is actuated if either of the duct drip pump circuit breakers is open. Piping and valving is provided whereby a part of the drip pumps' discharge is recirculated through the duct tee section to permit operation of the drip pumps during start-up and shutdown of the Unit.

\section{TURBINE EXHAUST DUCT}

\section{Manufacturer}

Purchase

Shel1

Material

Rectangular Section and Transition Section

Tee section and

Il fty dia, section Wye Branch

$8 \mathrm{ftr}$ Dia. Sections

Exterior Stiffeners, Supports

Expansion joints

Manufacturer

Material

Supports:

Transition Section

Tee Section

Vibration Snubbers
Saracco Tank and Mfg. Co. 4-R 42549

Type 304L stainless steel

$3 / 8$ iner plate

$5 / 16$ Inch plate

$3 / 8$ inch plate

$5 / 16$ inch" plate

ASTM A-36 steel

TempFlex Co.

$\mathrm{T}_{304} \mathrm{El} \mathrm{C}$ stainless steel

2 - Bergen V.S. 1 F19

4- Bergen DSV-4 Type D

2 - Barco Vibrasnub

No.10-50513 4 inch

4 - Barco Vibrasnub

No.10-50512 2-1/2 Inck 
Weights (estimated)

Elbow Section

Wye Branch and Elbows

Tee Section

3. EXHAUST DUCT DRIP PUMP

Number of units

Manufacturer

Purchase Order

Type of Pump

Pump Size

Fluid Pumped:

Temperature

Capacity

Head.

Speed

Flanges

Pump Serial Numbers

4. EXXAUST DUCT DRIP PUMP MOTOR

Number of Units

Manufacturer

Horsepower

Volts

Phase

Cycle

Frame

RPM

$$
\begin{aligned}
& 31,507 \quad \mathrm{lbj} \\
& 44,167 \mathrm{lb} k \\
& 36,280 \mathrm{lb} k
\end{aligned}
$$

2

Peerless Pump Division, FMC

4R-45269

Centrifugel, horizontal shaft

$2 \times 3 \times 8-1 / 2$

Water

$125^{\natural} \mathrm{F}$

$60 \mathrm{gpm}$

$50 \mathrm{ft}$

$1750 \mathrm{rpm}$

$1501 \mathrm{~b}$ ASA, $1 / 16$ inch

raised face

208597, 203598

2

General Electric Company

2

440

3

60

184

1800 
LUBRICATING OII SYSTEM

A. General Description

011 systems are provided to lubricate the turbine-generator bearings, to supply the harbine controls, and to seal the generator shaft openings against hydrogen gas leakage. The hydrogen seal-oil system is separately described in the section describing the generator.

An oil reservoir is provided by the turbine manufacturer. It is vented to atmosphere through an a-c motor driven vapor exhaust blower or through a $d-c$ motor driven stand-by exhauster. The main oil pump, the auxiliary oil pump, the a-c stand-by oll pump, and the turning gear lubricating oil pump all take oil from the reservoir. The reservoir receives oil arains from the bearings and the turbine control systems! It afso can recelve oll either from delivery truck or from the lubricating oil filter pump.

The turbine oil reservoir sits on top of a lubricating oil storage tank, which is divided into two compartments for the storage of clean and dirty oil. Any overflow from the dirty o1l storage compartment discharges to a sump well. A three compartment filter system by Bowser Company is provided for oil purification.

Two full capacity oil coolers are provided to recẹive lubricating 011 and cool it to - F before $1 t$ is delivered to the bearing oil beader. The ralve arrangement permits servicing one cooler at a time without shutting down the Unit.

B. MATN LUBRICATING OIL PUMP

The main lubricating oil pump is a centrifugal unit mounted on the governer end of the turbine shaft. The pump discharges at approximately 150 psig when operated at rated speed with a 20 psig suction head. The pump is not self priming, about one half of Its discharge flow is used to operate an ejector located in the lubrlcating oll reservolr which in turn supplies the 
suction pressure for the pump. Initial priming auring the start-up is provided by the auxiliary lubricating oil pump.

\section{c. AUXILIARY LUBRICATING OIL PUMP}

The auxlliary lubricating oil pump is a vertical shaft centrifugal unit mounted on the lubricating oil reservolr. It is driven by $a$ $30 \mathrm{hp}, 480$ volt, 3 phase motor. It supplies both the control oil and lubricating oil requirements of the Unit during start-up and shutdown.

If automatic operation of the pump is selected the pump will start on a drop of the main oil pump discharge pressure to 60 psig (APS-3).

\section{D-C STAND-BY LUBRICATING OII PUMP}

The d-c stand-by lubricating oil pump is provided to supply lubrication for the turbine-generator bearings during roll-down after an overall Unit trip.

If automatic starting of the pump is selected the pump will start on a drop of bearing oil header pressure to 4 psig (APS-I). The pump will shut down on a rise in oil pressure to 6 psigg which would occur on starting of the a-c motor driven auxiliary oll pump, or it can be shut down manually. In addition a timer is provided that can be set to trip the pump motor after a period of time sufficient for the roll to a stop. The purpose of this timed trip is to save station battery capacity for operation of the d-c operated seal o1l stand-by pump.

\section{LUBRICATING OIL DISTRIBUTION AND USE}

The 150 Ib $\not$ oil system Is used directiy to operate the main pump ejector and to provide hydraulic operating power to the turbine steam admission valves. A compination of a reducing orifice (RO-2) and a rellef valve ( $R V-3)$, provide oil from the 150 Ib system to a 75 lht system which serves the turbine governer with control oll and serves the turbine trip valve system. 

A motor-driven turning gear is provided to rotate the turbine-generator rotor during shutdown to minimize rotor distortion during the cooling-off period. It can also be used to rotate the turbine for start-up or to jog the rotor into a desired position for maintenance. Turbine rotation when driven by the turning gear is approximately $10 \mathrm{rpm}$.

The turning gear motor is locked out of operation if pressure in the turbine-generator bearing lubrication header is less than 4 psig. 
B. GENERATOR

1. Gététón General Description

The Unit 3 generator is a $3,600 \mathrm{rpm}$, hydrogen cooled, 13,800 volt, two pole, three phase, sixty cycle synchronous generator.

CIt is wye-connected, with-exeitation-power taken-from-currentexcitation equipunt and equiphed with stafic voltage vottage transformers-inserted-between-generator-winding-terminals-and the requlation equepincut. we-connection point.

Auxiliary equipment required for and supplied with the generator are a hydrogen gas supply and control system, a carbon dioxide gas supply and control system, a seal oil system, a gas dryer system, gas purity the Indication equipment, water detection equipment, and an excitation and voltage control system.

2. Generator Ratings

a) The generator is rated, at 30 psig hydrogen gas pressure, with both hydrogen gas coolers in operation, continuous capability:

\begin{tabular}{ll} 
Kva & 32,000 \\
\hline Pf & 0.90 (1agging) \\
Kw & 28,800 \\
Volts & 13,800 \\
Amperes & 1,340 \\
Short Circuit Ratio & 0.65
\end{tabular}

b) Continuous capability, when operated at 0.95 pf 1 eading and at $95 \%$ of rated voltage, is $28,000 \mathrm{kw}$.

c) Continuous capability at 0.90 pf 1 eading and at $95 \%$ of rated voltage is $26,000 \mathrm{kw}$. 
d) Continuous capability when operated at rated conditions except with one hydrogen cooler out of service is $19,500 \mathrm{kw}$.

e) Maximum temperature rises with gas cooling supply not exceeding $46 \mathrm{C}$, and with gas pressure of $30 \mathrm{psig:}$

Stator Winding (by detector)

Field Winding (by resistance)

Collector (by thermometer)

Core and Mechanical Part

(by thermometer)

$64 \mathrm{C}$

f) Insulation Dielectric Tests:

Stator

:

Rotor

8) Excitation Requirements at Rated Conditions:-

Kw

120

Volts

h) Volume to be Gas Filled: $720 \mathrm{cu}$ ft.

1) Cooling Water

Temperature

Quantity

Pressure Drop

3. Generator Construction

a) Stator

The frame consists of annular steel plates with spacing bars between them, enclosed by a steel wrapper plate, all electrically welded together. Bolting flanges are welded to the ends of the 
frame for attachment of similar flanges on the end domes. The frets bolted joint is made gas-tight by forcing a non-hardening sealIng compound into a groove in one of the mating members under high pressure.

Studs extending lengthwise of the frame at its inner periphery project through clamping plates at each end of the core and apply clamping pressure to the core. The studs are welded to intermediate annular frame plates. The studs and clamping plates are made heavy to eliminate any necessity for insulated clamping bolts extending through and surrounded by the core.

The core consists of silicon steel laminations, individually insulated with baked-on enamel. The laminations partly surrounded the axial studs at the inner periphery of the frame. The studs locate and key the laminations in place. Non-magnetic steel fingers maintain longitudinal clamping pressure on the teeth at both ends of the core.

Double frequency vibrations are present in two pole generators and consideration is given in the machine design to reduce and isolate the se 120 cycle vibrations. The core is supported by slotted frame plates lald out in a manner to provide an elastic mounting of the core structure inside the frame, which isolates the vibration. The core stacking studs welded to the inner periphery of the slotted frame plates maintain a rigid core support within the elastic mounting. 
Radial ventilation ducts are provided at intervals along the core. cooling gas, Impelled by blowers located on the rotor, is forced into the generator air gap and out through radial vent ducts in the core. Laminations at each end of the core are stepped back to a larger diameter to facilitate entry of gas into the air gap. Some of the cooling gas is forced through ducts in the frame outside the core into chambers near the middle of the core. From these the gas is forced inward radially through core vent ducts to the air gap where it travels axially along the air gap, mingles with gas forced in from the ends of the air gap and is discharged radially outward through other ducts in the core. Hot spots in the middle of the core are eliminated by this ventilation system.

The generator coils are constructed with Class B insulation, vacuum pressure impregnated, and finished with a layer of glass tape and painted with black insulating varnish. To reduce corona, a semiconducting paint is applied to the straight sections of the coil and extended beyond the core. A laminated phenolic spacer, impregnated with semi-conducting material, is used between coil sides in the stator slots. Non-shrinking phenolic slot wedges are used.

The stator windings are braced to withstand forces imposed by fault currents. Rows of phenolic spacing blocks are fitted between ad jacent coils and lashed in place with glass twine, arch-bracing the end winding. Insulating plates are supported from the frame clamping plates, to which the colls are lashed with glass twine. Upper and lower layers of the end winding are also blocked apart at each of these supporting plates. 


\section{b) Rotor}

The rotor body and shaft ends are machined from a single piece heat treated carbon steel forging. Axial slots are milled in the outer periphery to carry the field coils. The outside surface of the rotor is grooved to reduce surface losses and to increase the surface available for dissipation of heat.

The rotor windings are of copper strap bent on edge. Insulation between turns consists of mica tape. Ground insulation consists of moulded mica slot cells for the embedded portions of the coils and additional mica tape on several of the top turns of each coil, finished with glass protective tape over end turns. The turns are varnished as they are placed in the slots and the rotor is baked. slot wedges are of high strength aluminum alloy.

The end turns of the rotor are held in place against centrifugal force by alloy steel cylindrical retaining bands shrunk on the ends of the rotor body. The bands are lined on the inside with asbestos phenolic insulation moulded in place. The outboard ends of the retaining bands are shrunk over end plate rings which extend toward the shaft a sufficient distance to cover and protect the coil ends. The end plates provide the means to protect and? mount axial-flow, blower Impellers, fare also drilled and tapped tpped to receive balance weights. 
End turns of the rotor coils are braced apart in axial and transverse directions with asbestos phenolic blocks. Radial slots in the sides of these blocks form vent ducts for cooling. Additional ventilation is drawn through slots beneath the rotor field coils and discharged through radial holes to the periphery of the rotor.

\section{Lubrication}

The two generator shaft bearings are lubricated from an oil header served by the turbine lube oil system. Oil discharged from bearing No. 3 is used to lubricate the coupling between the turbine and the generator. High temperature alarm and high temperature tripping is provided on the discharge oil from each bearing.

\section{Generator Cooling}

a) Generator Cooling - General Description

The Unit 3 generator is cooled by circulating hydrogen gas. Hydrogen is used instead of air because of its lower density and superior heat conducting properties. The hydrogen operates In a closed system in an allowable gas static pressure range between 0.5 and 30 psig. Axial-flow blowers mounted at each end of the generator rotor circulate the hydrogen gas. Four vertical-tube heat exchangers, located one at each corner of the generator frame, cool the hydrogen.

Precautions must be taken to avoid hydrogen leaking from or air leaking into the generator, both to conserve hydrogen and to eliminate the possibility of creating an explosive air-hydrogen mixture. Some hydrogen gas is lost from the system continually, and replacement is made from the hydrogen supply system. 
The generator she11 and end domes are constructed and fitted to eliminate gas leakage, and a special seal oil system is provided to eliminate gas leakage when the generator shaft extends through the end domes. In addition the shell and dome structure is designed to withstand forces resulting from an internal explosion. A carbon dioxide $\left(\mathrm{CO}_{2}\right)$ gas supply is provided to be used to avoid creating any hydrogen-air mixtures when the generator is shut down to be opened for inspection or maintenance work. When the generator is to be opened, all hydrogen gas in the generator is mas $x$ ? to be displaced with carbon dioxide gas before any air is admitted. When the generator is closed to go back into service the air in the generator is to be completely displaced with $\mathrm{CO}_{2}$ gas before any hydrogen gas is admitted.

b) Gàs Supplies and Generator Purge

A hydrogen gas manifold and a carbon dioxide gas manifold connect gas supply cylinders to the generator gas systems and provide control of the gases.

The hydrogen gas manifold has connections for four gas cylinders each containing, when full, approximately 220 scf of $\mathrm{H}_{2}$ at 2,200 psig. Manual shut-off valves are provided plus a solenoid operated shut-off valve (SSV-3). Pressure control valves (VPC-4 and VPC-5). provide hydrogen pressure adjustment within the range between: $0.5 \mathrm{psig}$ and $30 \mathrm{psig}$

A self contained three-way presure rellef valve installed in the manifold assembly upstream of a check valve (H-16) is provided to prevent overpressuring the generator on failure open of the 
pressure control valve VPC -5 . The relief valve vents to the gas vent line. Backup generator overpressure relief is provided by a rupture diaphragm which will discharge gas to the vent line. A manually operated generator vent valve is provided, as is the solenoid operated vent valve SSV-4. Pressure gages, sampling connections, and low hydrogen supply pressure alarm LPA-9 are also a part of the hydrogen manifold as sembly.

The carbon dioxide gas manifold connects eight cylinders to the system in one group of six and one group of two. One full cylinder of carbon dioxide at 800 psig contains approxi- mately 174 scf of gas.

Manual shut-off valves are provided, as is a solenoid operated shut-off valve SSV-5. Pressure regulation equipment for the carbon dioxide is not required, but a relief valve $(R V-5)$ is provided. A check valve, pressure gage, low pressure alarms and test connections are incorporated in the manifold assembly. A tap is taken from the $\mathrm{CO}_{2}$ manifold to supply purge gas to the hydrogen gas drier and to the hydrogen purity indicator.

c) Generator Purge

Automatic purging of the generator hydrogen gas is provided in case of Unit trip due to low generator seal-oil-gas differential pressure. For the automatic purge to be initiated it is necessary for the turbine stean trip valve to be closed (POS-2B), the generator air circuit breaker to be opened (contact M7-M8 on auxiliary switch of ACB 252-3) and the seal-oil-gas differential 
trip contact (PS-6) to be closed.

When these conditions are met solenoid valve SSV-4 is energized, opening the valve and venting the generator to the vent line; solenoid valve SSV-3 is de-energized, closing that valve and securing the supply of hydrogen to the generator, and SSV-5 is energized, opening the valve and admitting purge $\mathrm{CO}_{2}$ gas to the generator.

Manually operated valves are also provided on the manifolds to perform the purging operation and to perform the reverse purging operation to put the generator back into service.

d) Gas Drier and Water Detector

A hydrogen gas drier and a generator water detector are provided mounted on one assembly.

The water detector consists of a chamber with a float switch. Any water that may accumulate in the bottom of the generator Is drained to the water detector float chamber providing first a high level alarm (HLA-2) and, if the water level in the detector chamber rises to a higher level, a Unit trip (HLT-3).

The gas drier removes water from hydrogen by passing it through an activated a lumina dessicant. The intake of the drier is connected to a high pressure region of the generator and the drier discharge is connected to a low pressure region, thus a a generator gas impeller provides energy to circulate the gas through the drier. 
A glass port is provided on the side of the drier to give visible indication of the condition of the dessicant. A glue-purple color Indicates that the dessicant can absorb additional water from the gas; a white or pale pink color indicates a need for regeneration.

Regeneration is accomplished by securing the flow of hydrogen, purging the drier with $\mathrm{CO}_{2}$, and then passing air, by means of the blower provided, through the electrically heated drying chamber, venting to the vent stack.

e) Generator Seal oil System

(1) Shaft Seals

A shaft seal is provided at each end of the generator, where the shaft penetrates the generator housing. The construction of the seal is similar to a thrust bearing with a spring loaded non-rotating sealing surface rubbing against a collar which is fixed to the shaft. $0 i 1$ is introduced into a circular groove in the non-rotating member at a pressure above that of the gas in the generator. Part of the oil flows toward the air side of the seal, lubricating and cooling the seal, and the rest flows inward toward the hydrogen side of the seal, preventing leakage of the gas. Labyrinth seals and a shaft slinger groove prevent creepage of seal oil further along the shaft into the generator.

(2) Sea1 oil Supply

The seal oil supply unit uses oil from the turbine-generator lubricating oil tank. The oil is cooled and then pumped through a filter to the shaft seals. 
The main seal oil pump is driven by a 3 horsepower, 480 volt, 3 phase motor with a manual start and stop control.

The first backup supply for the seal oil system is the turbine shaft mounted lubricating oil pump. This pump, when the turbine is in operation, maintains approximately 75 psig oil pressure to an emergency seal oil pressure regulator (VCP-2) which in turn maintains a pressure providing any required backup supply.

A second seal oil backup supply is provided by a d-c motor driven pump. The motor is a 5 horsepower, 125 volt motor supplied from the station battery. The motor control switch provides selection of "OFF", manual or "AUTOMATIC" start. If automatic starting is selected, starting will be initiated by APS -4 on a drop of seal oil pressure to ___ psig.

A check valve isolates APS 4 from the pressure rise caused by the pump it started and prevents start-stop hunting. If seal oil supply pressure is restored by the main seal oil pump or by the $751 \mathrm{~b}$ oil system APS-4 will stop the d-c pump motor, otherwise once started the motor will continue to run until it either trips on overload or is stopped manua11y.

A third seal oil backup source is the turning gear oil pump.

This pump is driven by a 480 volt a-c, 5 horsepower motor and will provide enough oil for operation at reduced hydrogen pressure. The motor control switch provides selection of manual or automatic starting. If automatic starting is selected, starting will be initiated by a drop in turbine lubricating oil header pressure to 8 psig. 
The motor will stop on a rise in pressure to 9 psig. An alarm is given when the turning gear pump is started.

The "Hydrogen System Trouble" alarm is given for a drop in pressure at LPA-4 (located on the main seal oil pump discharge) to psig.

Unit trip is initiated on high seal oil temperature (HTT-9 and HTT-10) and by low seal oil-gas differential pressure PS- 6 .

\section{(3) Detraining Tank}

Oil traveling through the generator seals entrains a small amount of hydrogen gas which is removed in a detraining tank before the oil is returned to the lubricating oil reservoir. In the detraining tank the oil flows over a system of plates and baffles; the gas evolves as the oil flows through. As the pipes from the generator seals to the detraining tank are only partly full of oil the evolved gas returns to the generator through these pipes. Flow of oil through the detraining tank is slow; in the order of a few ounces per minute.

The oil level in the detraining tank is maintained by an external float control ( $(\mathrm{C}-1)$. On release from the detraining tank the oil passes through a gas trap and is returned to the lubricating oll reservoir. High or low oil level in the detraining tank will inftiate a "Hydrogen System Trouble" alarm (HLA-3 and LLA-3).

A detralning tank solenold operated vent valve (SSV-2) is provided to vent out contaminated hydrogen gas. The solenoid valve is actuated by a pushbutton. 


\section{Excitation and Voltage Regulation}

a) Excitation and Voltage Regulation - General Description. The ${ }_{\Lambda}$ excitation power requirement of the pinit generator field is in $120 \mathrm{kw}$ at 250 volts $\mathrm{d}_{x} \mathrm{cx}$ The power is supplied during operation by the Unit generator via a current-voltage transformer (CVT) static exciter. the stution A field flashing circuit is provided to supply generator fle ld current ${ }_{\Lambda}$ during battery start-up until self-excitation is established.

A static voltage regulator is provided to control the generator voltage output. Control is effected through the controlled d-c output of the voltage regulator which energizes control windings of the exciter's CVI transformers.

No field current circuit breaker is provided; a fleld shorting system removes excitation from the generator fleld without creating the high voltage volgate associated with opening field current circuits.

Voltage regulation is available through either a manual or an auto$U$ ?

matic regulator system. A transfer switch located on the unit master control board provides selection of these systems, plus a "test" condition. On "test" the automatic voltage regulator is energized for testing, but generator excitation is under control of the manual voltage regulator. 'In autamatic operation, the generator base voltage is established by a voltage adjusting rheostat. In manual operation the voltage is controlled by the "Manual" rheostat. Both rheastats are motor driven and are operated through control rheostat. Both rheastats are motor dr? switches (VAR and MR) located on the unit master control board.

\section{b) Exciter}

The exciter consists of a three phase step down transformer, three single phase reactors, three $d-c$ controlled single phase current-voltage 
transformers (CVI's) and a three phase full wave power rectifier.

The CVTis have four windings each. One primary winding takes single kna

phase power from the 200 jo step-down transformer via a series reactor. The stepdown transformer is energized from the output of the finit generator
a measure of voltage

and provides power and vos the exciter. A second winding únit generator phese winding and on each CVT is connected in series between a unit generator phase winding and the generator wye point. The CVT vinding carries generator current and provides current sensitivity to the exciter. A third winding on each CVT is energized by the $d-c$ output of the voltage regulator. Current in this winding tends to saturate the CVI, providing control of 1ts output. The output windings of the CVI's supply three phase full wave diode rectifier. The rectified output supplies the unit generator field.

Dual rectifier units are provided, each capáble of carrying continuously full generated field current. Gang operated five pole switches will isolate the rectifiers so that one rectifier unit at a time can be isolated vithout shutting the unit down.

c) Voltage Regulator

The voltage regulator has two sections, providing manual or automatic regulation.

The manual control section has a single phase bridge rectifier composed of two solid state diodes and two silicon controlled rectifier (SCR) elements. The a-c output of the section is controlled by rarying the firing time of the SCR elements during each cycle of the regulator's a-c supply voltage. Control of the firing time is effected through the "manual" controlirheostat which varies the charging time of an R-C circult. The R-C circuit, with a unijunction transistor constitutes a relexation oscillator which provides gate signaI pulses to the SGR's of the rectifier. The controlled 
d-c output of the rectifier is applied, when the excitation system is under manual control, to the control wincings of the exciter CVI's.

The automatic section of the voltage regulator equipment is similar to the manual section, but has additional features. Cross-current compensation is provided to control the $U^{\prime \prime}$ it generator's response to system demands for reactive kva. A drooping response characteristic is required to prevent the generator from assuming more than its proportional share of reactive load. The control is effected by biasing the voltage regulator's input signal with a voltage proportional to the reactive current being carried by the generator. The bias voltage is derived from a $3000 / 5$ ampere current transformer (CCCT) in the B phase of the generator's winding-toneutral leads. A manually set rheostat in the voltage regulator cabinet provides adjustment of the cross-current compensation effect of the regulator. An underexcitation discriminator circuit is provided in the automatic voltage regulation section. The purpose of the underexcitation discrimination is to prevent lowering of generator excitation to the point of machine instability under conditions of leading geverath power factor. The discriminator circuit is sensitive to generator kilowatt load and ot leading power factor current. The output of the discriminator biases the voltage regulator's Input signal providing a minimum excitation level.

\section{d. Field Flashing}

A field flashing system is provided to excite the main generator field on staxtup until sustained self-excitation is effected. Field flashing is applied when the generator reaches rated speed, and is maintained until generator buildup occurs, generally about ten seconds. Power for field flashing is taken from the station battery; switching is accomplished through 
$-4-$

a relay. A "Field Flashing" pushbutton, located on the main control board actuates the relay provided the field shorting relay is open.

e) Field Shorting

A field shorting system is provided to remove field excitation from the main generator. The system consists of an electrically operated ? Unit relay which shorts out the output oi the current-voltage transformers which supply the exciter rectifier. The characteristics of the generator-exciter system are such that self-excitation cannot be maintained with the shorting switch closed as long as there is no external supply to the generator armature. It is essential that the main generator air circuit breaker (ACB 252-3) be open for the field shorting system to perform its purpose. Therefore a " $\mathrm{b}$ " contact on ACB $252-3$ is connected as a permissive for operation of field manual switch shorting. The field shorting control is located on the unit main control board. Field shorting is also inflated by operation of the Generator $A C B$ control sw, the Generator Lockout relay, and the Uni Lockout relay. 


\section{CIRCULATING WATER}

\section{SECTION INDEX}

A. Cooling Water

1. General Description

B. Cooling, Tower

C. Cooling Tower Supply Pump

D. Turbine Exhaust Condenser System

1. General Description

2. Condenser Supply Pump

3. Turbine Exhaust Condensers

4. Steam Set Ejectors

5. Inter Condenser

6. After Condenser

REFERENCES

Drawing

432594

432595

433117

\section{Title}

Piping and Instrumentation Diagram, Steam and Condensate

Piping and Instrumentation Diagram, Cooling Water

Schematic Diagram, Condenser Supply, Cooling Tower Supp1y, and Fan Motors 


\section{A. Cooling Water}

(1) General Description

Cooling water is provided for the condensers, the generator hydrogen coolers, the lubricating oil coolers, the hydrogen seal oil coolers, and the gland steam eductors.

The cooling water system is a circulating system in which the water is cooled by evaporation in a cooling tower. Water is lost from the system by evaporation and by rejection to drainage. Water is added to the system by condensation of exhaust steam. The water added is expected to exceed the losses under all operating conditions so additional makeup should not be necessary. The initial start-up charge of water is obtained from the water system provided for fire protection.

The water from the condensers including the condensate, is discharged into a seal well which insures a water seal on the discharge pipe outlets. The seal well discharges to a hatwe11. The cooling tower supply pump takes water from the hotwe 11 and pumps it to the cooling tower through a 36-inch ID concrete pipe, a 24-inch header and three 24-inch riser pipes. A butterfly valve is provided in each riser to permit adjustment of the water flow to each section of the cooling tower.

The cooling tower basin drains to the cold well. The cold well overflow is connected to the hotwell to equalize the water levels and balance the fllows in the circulating system. This connection, bypassing the cooling tower supply pump and the cooling tower, will prevent the condenser supply pump from losing suction should the cooling tower pump fail or during start-up when the condenser supply pump is used without the cooling tower supply pump.

The condenser supply pump picks up water from the cold well and pumps to the cooling water distribution system.

The cooling tower supply pump and the condenser supply pump are each driven by a 400 horsepower, 480 volt motor. Each motor is manually started and stopped. The cooling tower supply pump motor will be tripped if the condenser supply motor circuit breaker is not closed, therefor the condenser supply pump must be started first.

A trip of elther the condenser supply pump motor or the cooling tower supply pump motor will, if the main generator circuit breaker is closed, trip the Unit. 
B. Cooling Tower

Manufacturer

Type

Manufacturer's model number

Design flow

Design water inlet temperature

Design water outlet temperature

Design wet bulb temperature

Design wind velocity

Number of fans

Number of blades per fan

Fan Diameter

Fan blade material

Fan Speed

Tip speed

Fan motor hp

Fan speed reducer

Fan stack

Static pumping head above basin curb

Dimensions :

length

width

height
Fluor Products Co.

Three cell counterflow induced draft

3F60 B2184V-3666B4P

$29,000 \mathrm{gpm}$

$119 \mathrm{~F}$

$80 \mathrm{~F}$

$65 \mathrm{~F}$

$0-10 \mathrm{mph}$

6

4

$18 \mathrm{ft}-0 \mathrm{in.}$

A1S1 T-302/304 stainless stee 1

$193 \mathrm{rpm}$

$10,900 \mathrm{ft}$ per min

75

Fluor-Western Mode1 FWD-75, Double reduction spiral bevel gear

$14 \mathrm{ft}-0$ in, parabolic ventur1

$41 \mathrm{ft}$

$109 \mathrm{ft}$

$66 \mathrm{ft}$ plus $6 \mathrm{ft}$ louver extension

$43 \mathrm{ft}$ plus $14 \mathrm{ft}$ fan stack 
B. Cooling Tower (cont'd)

-

Materials :

structural framework

joint connectors

bolts

nuts

fill

sheathing

Water distribution system

Nozzles
Clear heart redwood

Type $356 \mathrm{~T} 6$ aluminum

Type $6061 \mathrm{~T} 6$ aluminum

Type 606 IT6, or $6062 \mathrm{~T} 9$ aluminum

High impact polystyrene

Flat $1 / 4$ in. cement asbestos board

Redwood stave pipe

Polypropylene 


\section{COOLING TOWER PERFORMANCE CURVE}

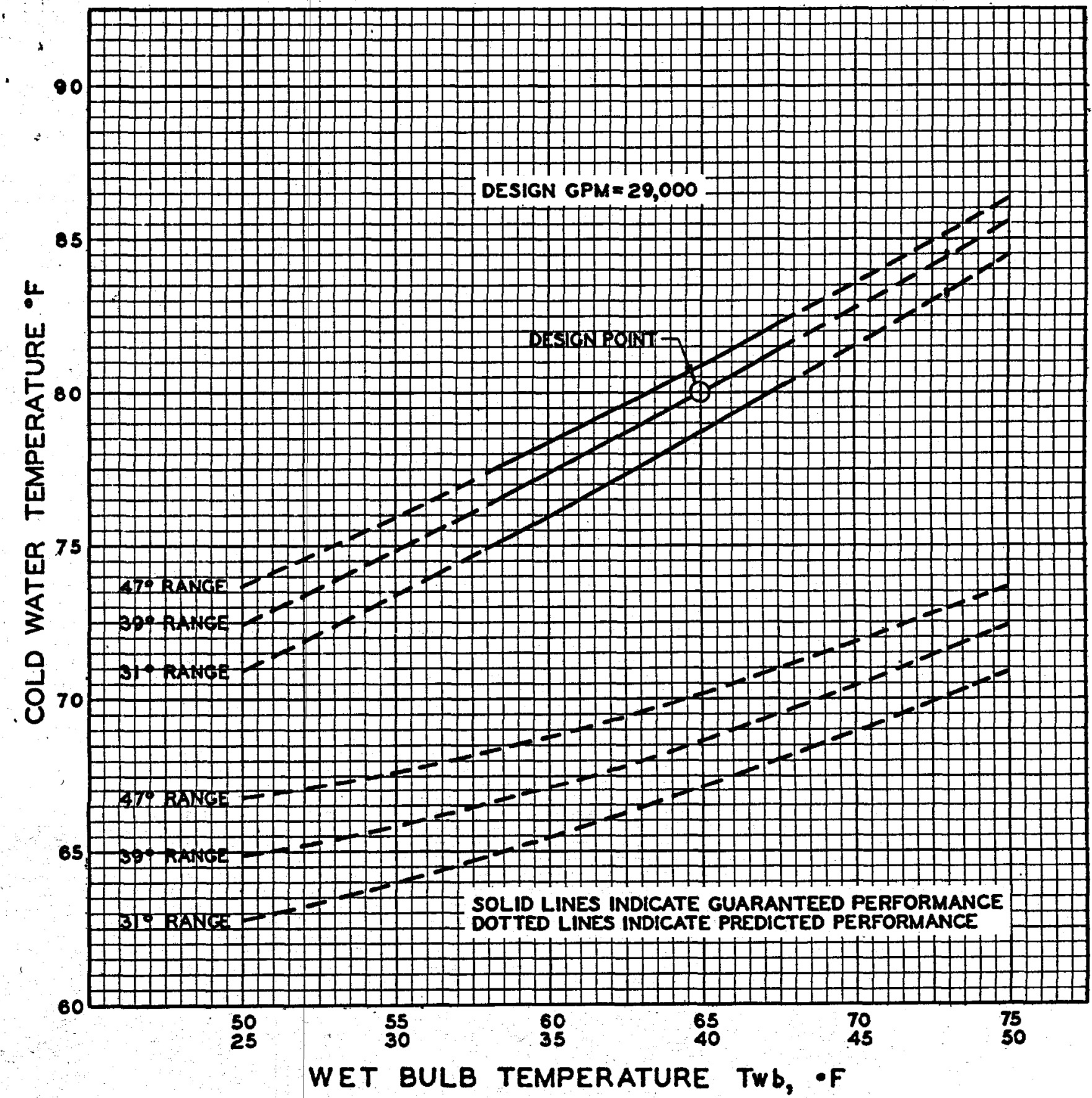




\section{COOLING TOWER PERFORMANCE CURVE}

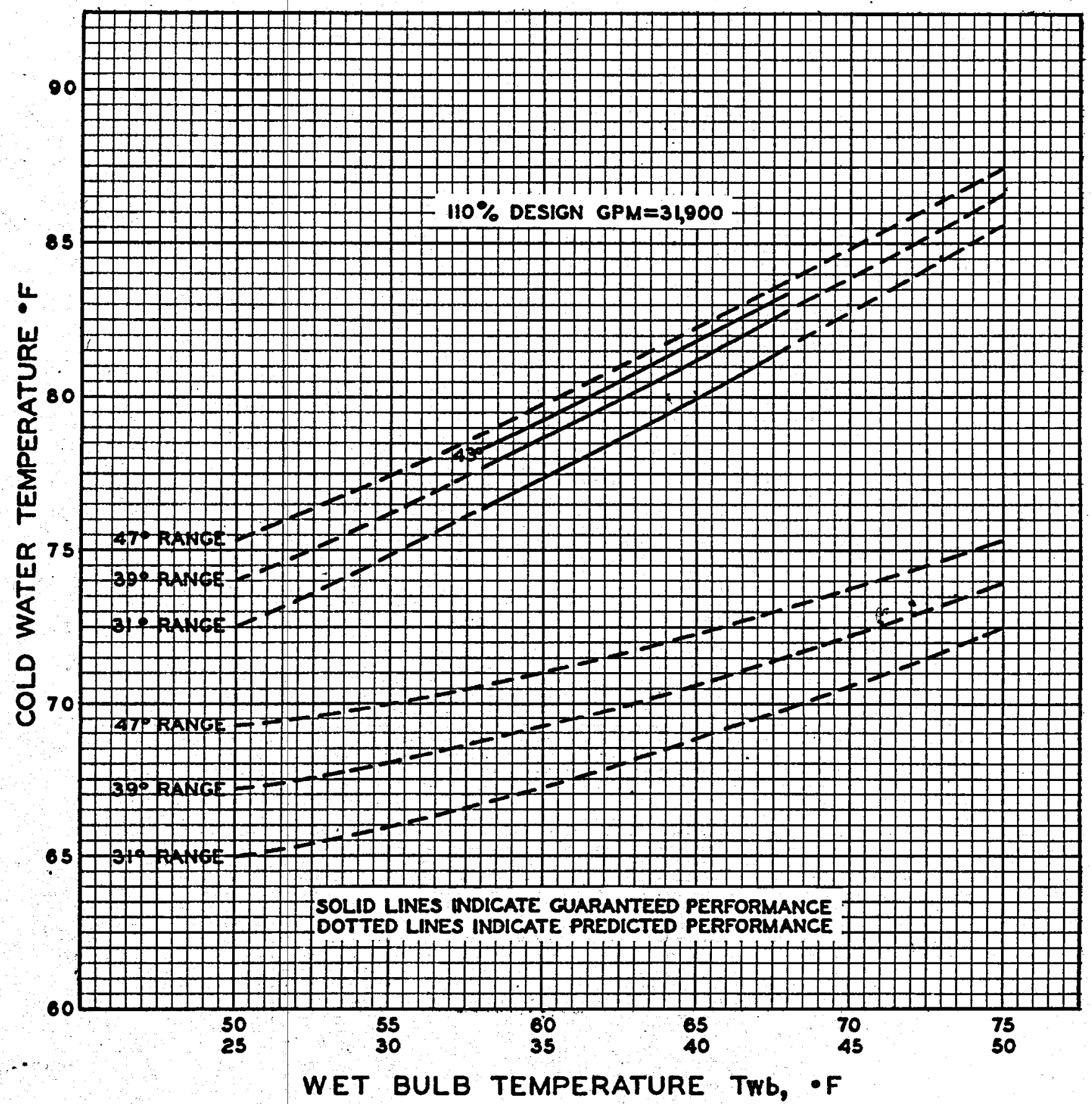




\section{COOLING TOWER PERFORMANCE CURVE}

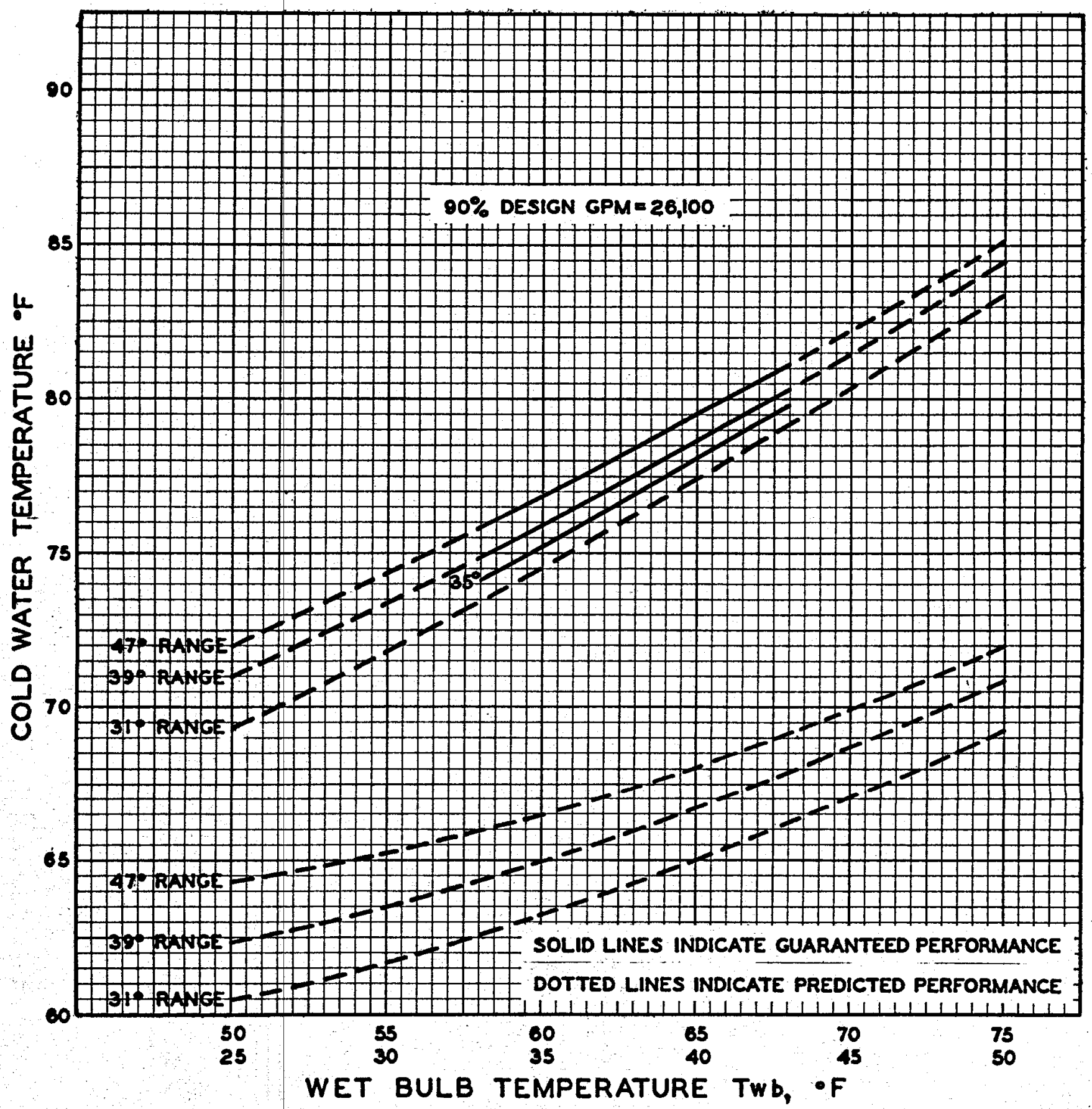




\section{COOLING TOWER \\ PERFORMANCE CURVE}

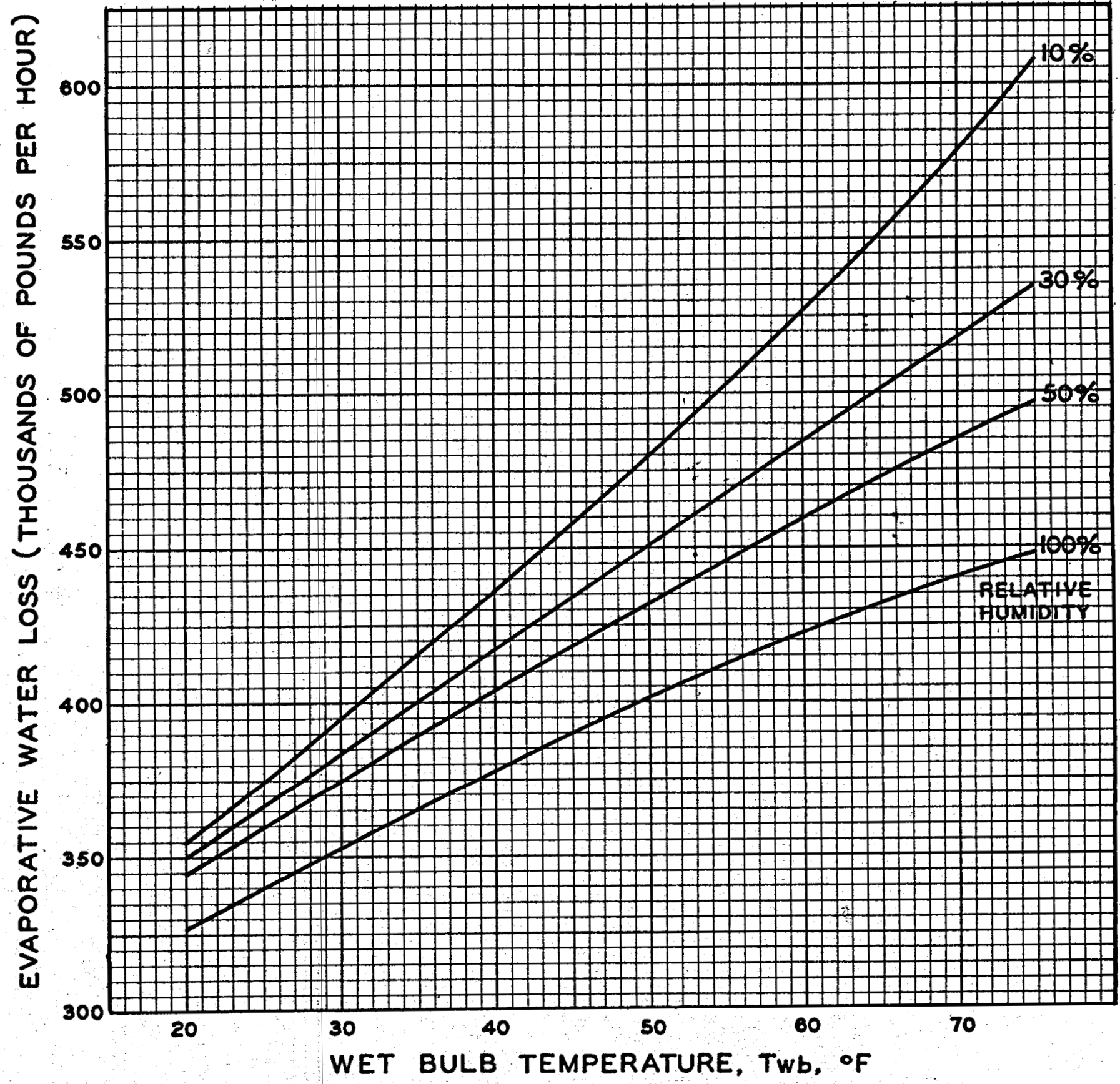

\footnotetext{
DESIGN CONDITIONS:

GPM $29,000 \quad T_{1} 119^{\circ} \mathrm{F}$

Twb $65^{\circ} \mathrm{F} T_{2} 80^{\circ} \mathrm{F}$
} 
Application : Cooling Tower Fan

Quantity. 6

Manufacturer Genera WESTINGHOUSE

Rated E.P. 75

Frame $444 \mathrm{U}$

Volts 440

Speed rpm

IIEXA Deṣign B

Vertical or Eorlzontal Shaft Horlzontel

Cooling

Connection to Equipment

Bearings

Lubrication

Welght in $1 \mathrm{bs}$.

Hinding Connection

WYE

A-1007

1880 volts a-c 1 min.

Dielectric Test

Temperature RIse

Amps:

Rated Load 95.0

Torques:

Rated Ioad

Power Factor: Rated Load

Efflclencles: Rated Ioad

Rotation:

Remarks:

Syneh. 1800

Stator 650
Poles 4

Cycie 60

Enclosure TEFC

self-air

Coupling

Ball

Grease

Rotor 390

INo. of Ieads Brovight Out 3
Rated Ioad 1775

Service Factor 1.00 
C. Cooling Tower Supply Pump

Number of Units 1

Manufacturer Peerless Pump Division, FMC

Manufacturer's Type 36 $\quad 3 \mathrm{HH}$, single stage indus-

trial turbine

Shaft

vertical

Pump Serial Number

207576

Purchase Order Number

Quantity Pumped (Design)

Field Head

$4 R-37524$

$29,000 \mathrm{gpm}$

$45 \mathrm{ft}$

$\mathrm{Rpm}$

705

Drive Motor

$400 \mathrm{hp}$

Suction

38 in. dia

Bow1

$36-3 / 16$ in. dia

Bow1 Materia1

316 stainless steel

Bushings

carbon

Bowl Wear Rings

316 stainless steel

Shaft, Couplings, Column

316 stainless stee 1

Discharge

horizontal, 36 in. O.D.

Discharge Flange

$3 \mathrm{ft}-10$ in. O.D.

Weights

Motor

$5,3001 \mathrm{~b}$

E1bow

$4,8001 \mathrm{~b}$

Bowl Unit

$3,7401 \mathrm{~b}$

TOTAL

$13,8401 \mathrm{~b}$ 
D. Turbine Exhaust Condenser System

1. Genera1 Description

Steam exhausted from the turbine is condensed and noncondensible exhaust gases are removed by a barometric condenser system equipped with two stages of steam ejection. An intercondenser, an aftercondenser and a vapor exhaust separator are provided in conjunction with the ejectors.

The system is designed to handle $509,000 \mathrm{lb}$ per $\mathrm{hr}$ of turbine exhaust, providing a back pressure of $3.75 \mathrm{in}$. of $\mathrm{Hg}$ abs. The exhaust consists of $503,400 \mathrm{lb}$ per hr of steam of molecular weight 18 , and $5,6001 \mathrm{~b}$ per $\mathrm{hr}$ of noncondensible gases of an average molecular weight 31.4 .

Total cooling water requirement for the condenserejector system is 24,752 gallons per minute at $80 \mathrm{~F}$; t the total mative steam requirement for the ejectors is 22,800 Ib per hr. Normal barometric pressure at the installation is taken as 27.9 in. Hg. 
1. Condenser Supply Pump

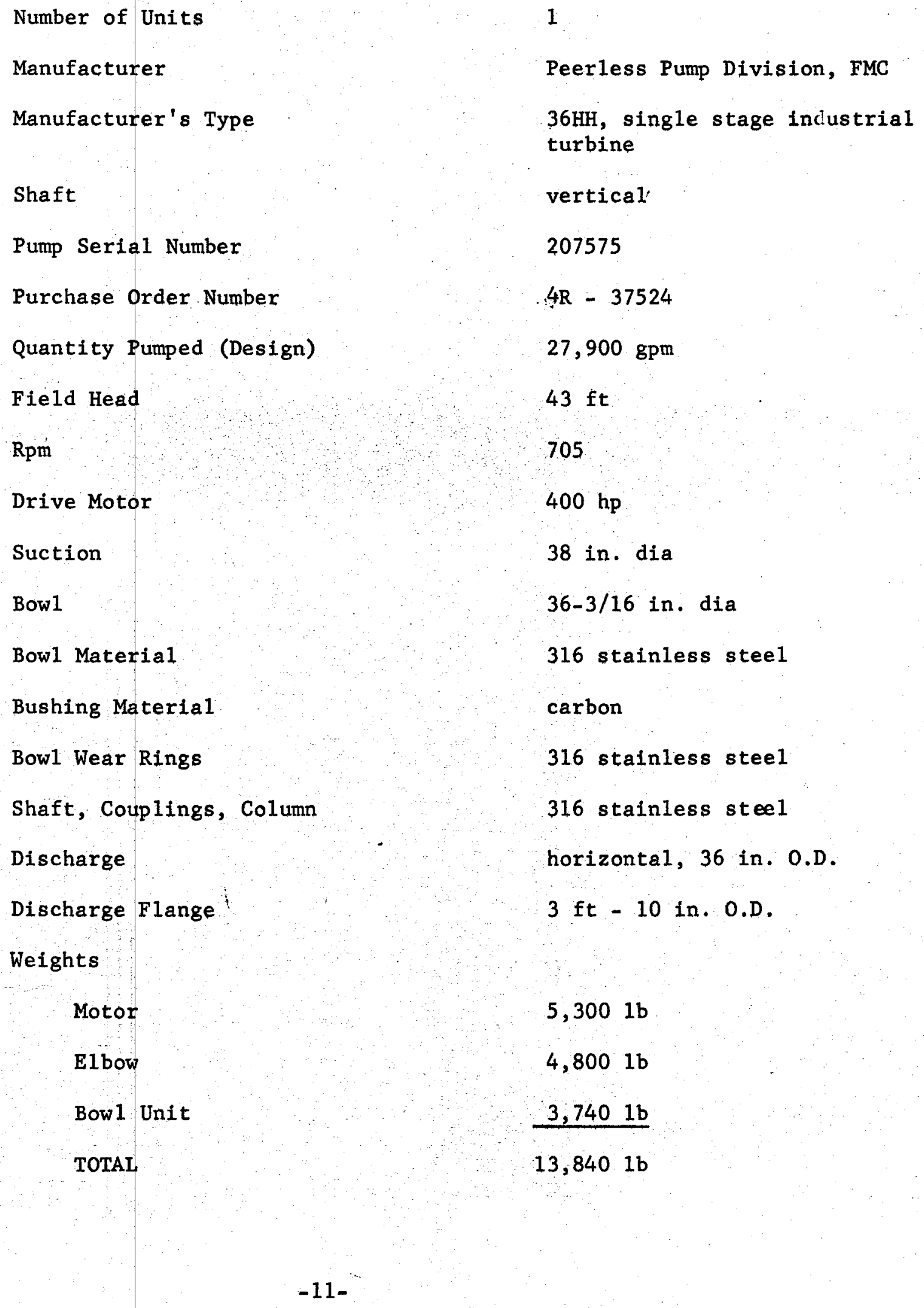


2. Turbine Exhaust Condensers

Number of units

Type

Manufacturer

Size

Design Duty:

Cooling Water Flow

Cooling Water Temperature

Water Temperature Rise

Back pressure

Material:

She11

Tray

Water nozzle

Weight:

Empty

Operating

Fu11 of water
2 (connected in paralle1)

Barometric

E11iott Company

132 in. (diameter)

Condense 509,000 1b per

hr exhaust steam

$11,625 \mathrm{gpm}$ each

$80 \mathrm{~F}$

$39.8 \mathrm{~F}$

$3.75 \mathrm{in.} \mathrm{Hg}$ abs

Carbon steel

Clad with $316 L$ stainless steel

$316 \mathrm{~L}$ stainless stee 1

316L stainless steel

$37,0001 \mathrm{~b}$

$42,0001 \mathrm{~b}$

$163,0001 b$ 
3. Steam Jet Ejectors

Manufacturer

E11iott Company

Number of stages

2

Design Conditions

Minimum steam pressure

Minu

Q ideam temperature

Maximum back-pressure on

final stage

1 psig

First Stage Ejector

Size (nomina1)

16 in $\times 16$ in.

Steam requirement

9,920 lb per hr

Second Stage Ejector

Size (nomina1)

10 in. $x 10$ in.

Steam requirement

$12,9001 \mathrm{~b}$ per hr

Material (both ejectors)

Steam chests

316L stainless steel

Steam nozzles

$316 \mathrm{~L}$ stainless stee 1

Suction chambers

316L stainless steel

Diffusers

316L stainless steel 
4. Intercondenser

Manufacturer

Number of Units

Size (nominal)

Design Conditions

Cooling Water Flow

Cooling Water Temperature

Water Temperature Rise

Material

She11

Water Nozzle

5. Aftercondenser

Manufacturer

Number of Units

Size (nomina1)

Design Conditions

Cooling Water Flow

Cooling Water Temperature

Water Temperature Rise

Material

She11

Water Nozzle
E11iott Company

1

60 in. (diameter)

$835 \mathrm{gpm}$

$80 \mathrm{~F}$

29F

316L stainless steel

$316 \mathrm{~L}$ stainless steel
Elliott Company

1

48 in. (diameter)

672 gpm

$80 \mathrm{~F}$

$40 F$

316L stainless stee1

316L stainless steel 


\section{CONDENSER VACUUM VERSUS CONDENSER LOADING}

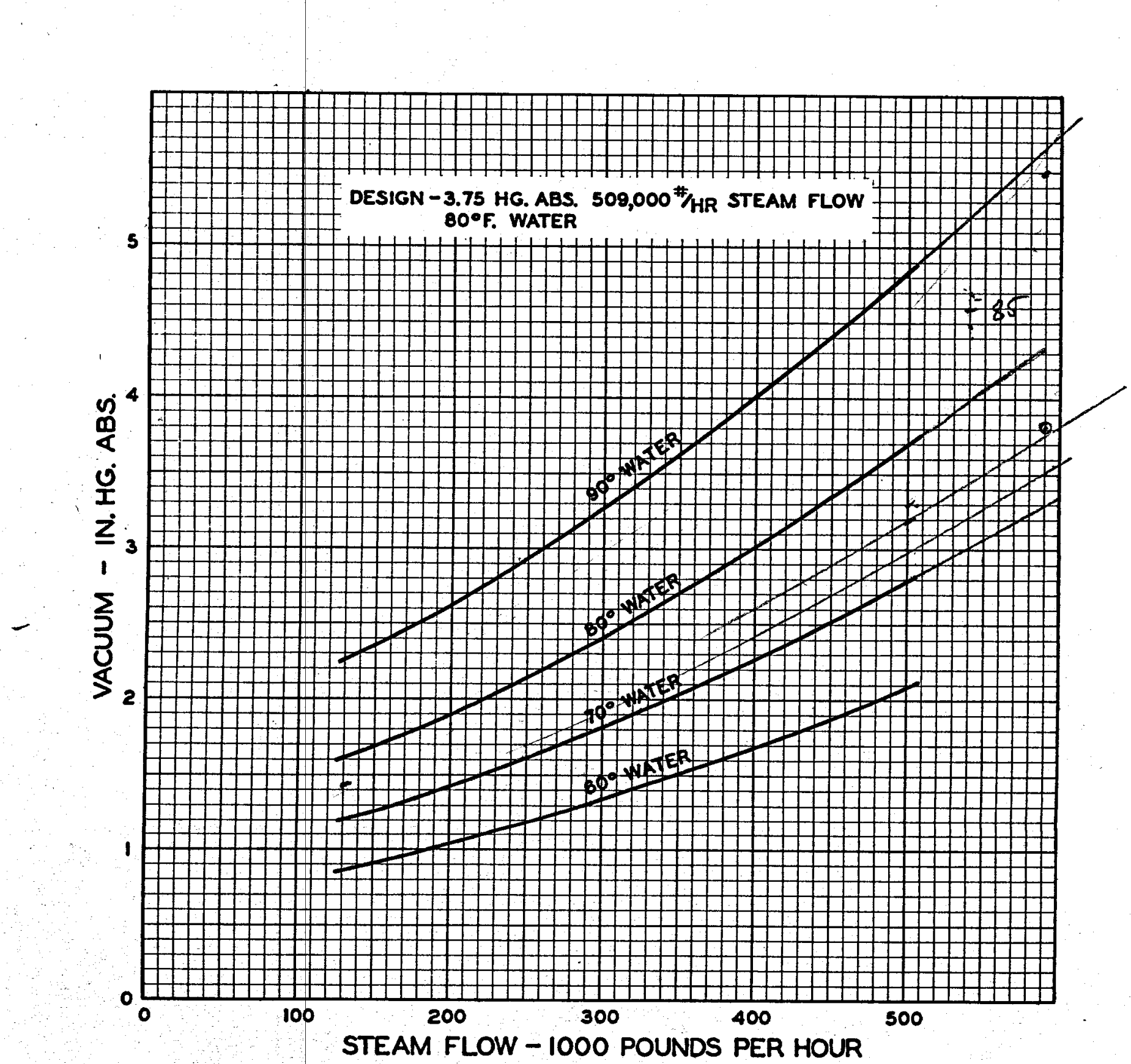




\section{SUCTION PRESSURE VERSUS CAPACITY FOR THE TWO STAGE EJECTOR SERVING THE MAIN CONDENSERS}

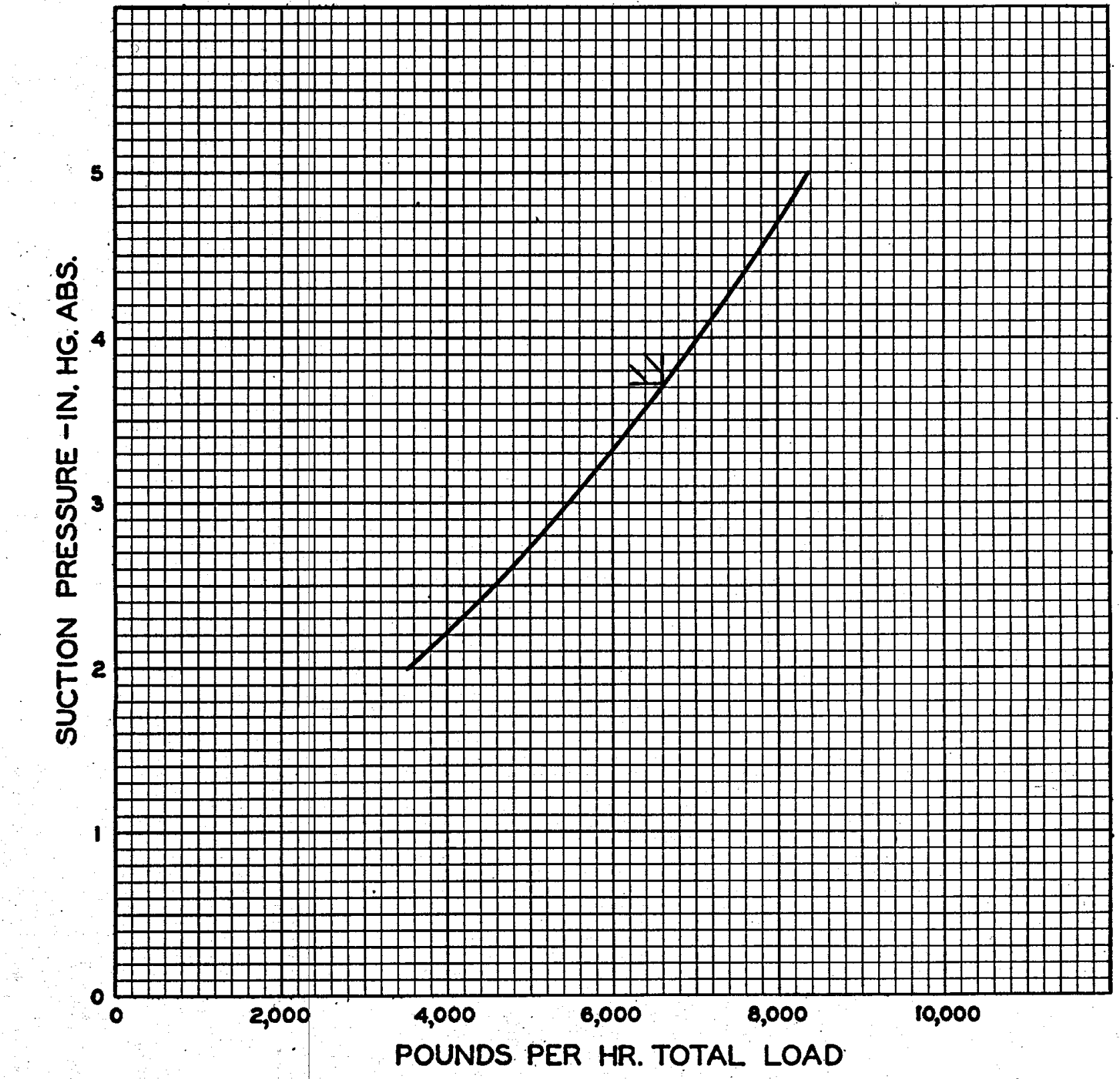




\section{PROTECTIVE RELAYS}

SECTION INDEX

A. Protective Relay System - General

B. Lockout and Tripping Schemes

C. Turbine Overspeed Trip

D. Relay Data

REFERENCES

Drawing

No.

433105 Functional Diagram, Turbine Generator Protection

433102 Single Line Meter and Relay Diagram

433107 Schematic Meter and Relay Diagram, Generator, Exciter, Regulator and Air Circuit Breaker 


\section{A. PROTECTTVE RELAY SYSTEM - GENERAL}

The design of the protective relay system of Unit 3 , like that of Units $I$ and 2 , is based on the consideration that the Unit, while requiring manual control for start-up, will operate unattended. This requires that many operating condltions that would initiate only an alarm in an attended plant must trip this Unit.

A sequentiel tripping scheme is used to trip the Unit in response to all mechanical and some electrical troubles that call for trip. The purpose of the sequential tripping is to protect against a turbine runaway should the generator air circuit breaker trip open and the turbine trip valve and the trip check valve fail to close. The sequential tripping is accomplished by using a Turbine-Generator Lockout Relay (286-3) to energize a solenoid dump valve $(\mathrm{SV}-1)$. The dump valve releases the auto-stop oil which causes closing of the turbine trip valve and the turbine check valve. Position switches on the valves infiate trip of the generator air circuit breaker when either the trip valve or the check valve closes.

The sequential tripping scheme is not used to trip the Unit in response to certain electrical faults. These are faults that require rapid tripping to minimize electrical damage, and in the se cases tripping of the auto-stop oil and of the generator air circuit breaker are initiated simultaneously.

The generator low frequency relay (281-L3) trips the Unit (through a lockout relay) only if the generator air circuit breaker is closed. This low frequency relay serves as a protection against power overload that might be imposed on the Unit by system switching. 


\section{B. LOCKOUT AND TRIP SCHEMES}

Protective relays and functions (except for turbine overspeed trip) initiate operation of one of five devices:

1. Solenoid Valve SV-1 - Solenoid Dump Valve

2. Device No. 286-3 - Turbine-Generator Trouble Lockout

3. Device No. 286F-3 - Generator Trouble Lockout

4. Device No. 386-3 - Unit Overall Lockout

5. Device No. $86 \mathrm{M}-3$ - 480 Volt Switchgear Lockout Relay

1. Solenold Valve SV-1 - Solenold Dump Valve:

The Solenoid Dump Valve, sV-1, opens when energized, releasing

pressure of the auto-stop oil, which trips the turbine. After the turbine trip, the generator air circuit breaker is tripped as explained above. All three lockout relays, (286-3), (286F-3), and (386-3) will energize SV-1. In addition, it is energized by a Bearing 0il Low Pressure Switch (PS-5), and by a manual Emergency Trip Control Switch $(205-3)$

2. Device No. 286-3 - Turbine-Generator Trouble Lockout Reley:

The Turbine-Generator Trouble Lockout Relay (286-3), when picked up, energizes the Solenoid Dump Valve (SV-I) and the 480 volt Switchgear Ipckout Relay (86M-3). The 480 volt Switchgear Lockout Relay, in turn, trips and locks out 480 volt auxiliary motors no longer required after a unit trip.

The Turbine-Generator Trouble Lockout Relay (286-3) is energized directly for twenty-six trouble inputs, through a time delay for one, (Low Hydrogen Purity), and through a "generator air circuit breaker closed" contact for four others. 
The functions and devices which will directly cause the 286-3 relay to operate are:

\section{FUNCTION}

(1) $\mathrm{H}_{2}$ Gas High Temperature

(2) Low Gas-0il Differential Pressure

(3) High Seal Temperature (Turbine End)

(4) High Seal Temperature (Collector End)

(5) $\mathrm{H}_{2}$, Gas Low Pressure

(6) Liquid Drain High Level

(7) Low H2 Purity (time delayed)

(8) $\mathrm{H}_{2}$ Gas High Pressure

(9) Generator Overcurrent Backup

(10) Generator Negative Sequence Current Relay

(11) Generator High Frequency

(12) Generator Loss of Field Relay

(13) Generator Overvoltage

(14) Generator Field Ground

(15) Generator Stator High Temperature

(16) Turbine-Generator Vibration Detector

(17) Turbine-Generator Bearing High Temperature

(18) Turbine Exhaust High Temperature

(19) Turbine Oil High Temperature

(20) Rotor Movement

(21) Bearing Oil, Low Pressure

(22) Exhaust Duct, Drip Pumps off

(23) Water in Turbine Exhaust Duct
DEVICE

HTT-5, HIT-6

PS-6

HTT-9

HIT-10

PS-11

HLT-3

$74-x-10-3$

PS-7

$251-V-3$

$246-3$

$281-\mathrm{H}-3$

$240-3$

259-3

264-3

226-3

V IB

HTI-1 through HTT-8

HTT-11

HTI-7

POT-7, POT-8

PS-13

$42-20,42-21$

HLT-1, HLT-2 
(24) 480 Volt Bus Undervoltage

(25) Main Transformer, High Temperature

(26) Main Transformer, Sudden Pressure

(27) Turbine 011 Low Pressure
$27-3$

26-Q

63-FP

PS- 5

The functions which will cause operation of the 286-3 relay only 1f the generator air circuit breaker is closed are:

\section{FUNCTION}

(1) Generator Low Frequency

(2) Condenser Iow Vacuum

(3) Cooling Tower Supply Pump Breaker Open

(4) Condenser Supply Pump Breaker Open
DEVICE

281 L-3

PS-1

$52-8$

$52-7$

3. Device No. 286F-3 - Generator Trouble Lockout

Operation of the Generator Trouble Lockout Relay (286F-3) does not inftiate the sequential tripping action as it is desirable to disconnect the generator quickly to minimize electrical damage. Therefore the $286 F-3$ energizes the solenoid Dump Valve, the generator air circuit breaker trip circuit, and the 480 volt switchgear lockout relay simultaneously.

The $286 \mathrm{~F}-3$ is operated by three functions:

FUNCTION DEVICE

(1) Generator Neutral Overvoltage $259 N-3$

(2) Generator Neutral Instantaneous Overvoltage $259 I-3$

(3) Generator Differential Current 287-3

4. Device No. 286-3 - Unit Overall Lockout Relay

The Unit Overall Lockout Relay (286-3) trips the same devices as the Generator Trouble Lockout Relay (286F-3), as listed above. In addition it initiates tripping of the $60 \mathrm{kv}$ air circuit breaker (OCB No. 42). 
Device No. $286-3$ is energized by operation of the following:

\section{FUNCTION}

(I) Unit overall Differential Relay 387-3.

(2) Auxiliary Transformer Overcurrent 251-3

(3) Station Battery Undervoltage 80-3

(4) $60 \mathrm{kv}$ Line Overcurrent 351-1

(5) $60 \mathrm{kv}$ Iine Ground Overcurrent 351N-1

5. Device $86 M-3$ - 480 Volt Switchgear Lockout

The 480 Volt Switchgear Lockout Relay trips circuit breakers in the motor control center that feed the condenser supply pump, the cooling tower supply pump, and the cooling tower fans.

The 86M-3 device is tripped through operation of the TurbineGenerator Trouble Relay (286-3), the Generator Trouble Relay (286F-3), or the Unit Overall Lockout Relay (386-3). 


\section{LIST OF RELAYS}

Device

$27-3$

$27-B C$

$74-3$

74-TG

$80-3$

$86 M-3$

$226-3$

$240-3$

246-3

251-3

$25 I V-3$

$259-3$

$259-N-3$

2591-3

264-3

$28 I H-3$

$28 I I-3$

$286-3$

$286 \mathrm{~F}-3$

$287-3$

$290-3$

$351-1$

$351 N-1$

386-3

$387-3$

\section{Description}

480 Volt Bus Undervoltage

Battery Charger Undervoltage

Battery System Ground

Turning Gear Trouble Alarm

Battery Undervoltage

480 Volt Switchgear Lockout

Generator Stator High Temperature

Generator Loss of Field

Generator Negative Sequence

Auxlliary Transformer Overcurrent

Generator Overcurrent Backup

Generator Overvoltage

Generator Neutral Overvoltage

Gen. Neut. Overvoltage, Instantaneous

Generator Field Ground

Generator Overfrequency

Generator Underfrequency

Turbine-Generator Trouble Iockout

Generator Trouble Lockout

Generator Differential

Turbine Ioad Controller

Iine Overcurrent

Ground Relay

Unit Overall Iockout

Unit Overall Differential
Mfgr. Type-style

W.E. CV-2 1875508

(Part of battery charger)

Exide GDR GDR503

Struthers-Dunn A5BXX

Mole Richardson A500868-60B

W.E. CO. WL 300P758G0I

W.E. CO. KIF 290B48IAO9

W.E. CO. COQ 1956207

W.E. Co. CO-9 1875283

G.E. IJCV 12IIJCV5LAIA

W.E. Co. CV-25 290B569A2I

W.E. Co. CV-8 1875526

W.E. Co. SV 1876094

W.E. Co. DGF 1878175

W.E. Co. CF-1 291B995A09

W.E. CO. CF-1 291B995A10

W.E. CO. WL 300P758G0I

W.E. CO. WL 300P758G01

W.E. Co. HA 1876163

I\&N

$69627 A 1$

W.E. Co. CO-9 1875289

W.E. Co. $\mathrm{CO}-91875283$

W.E. Co. WL 300P758G01

W.E. Co. CO-8 1875273 


\section{MAKE-UP WATER AND FIRE PROTECTION}

\section{SECTION INDEX}

A. General Description

B. Intake and Pump Sump

C. Make-up water Pump

D. Pump Controls

E. Water Storage

F. Water Distribution

Drawing Number

432597

433119

433163

433164

.433173

212538

Recora Number

657498

\section{REFERENCES}

Title

Piping and Instrumentation, Miscellaneous Service Systems

Schematic Diagrams, Miscellaneous Service Systems

Water Supply and Fire Protection System

Water Supply Intake

Requirements for Water Supply Tank

AssembIy of Material for Standard

Wood Shelter for Fire Hose

Title

Manufacturer's Setting Plen, Nake-up Water Pump 


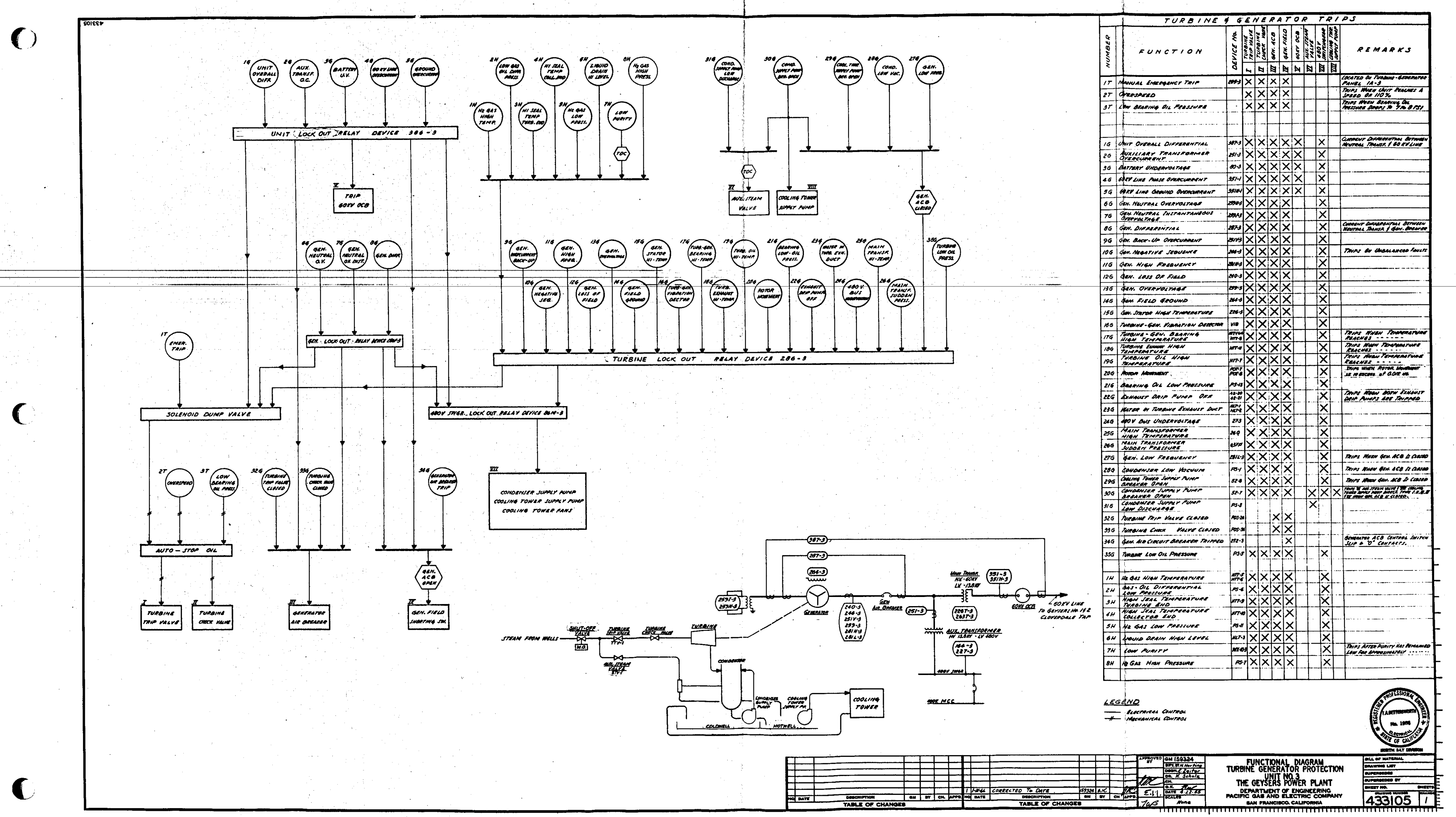




\section{MAKE-UP AND FIRE PROTECTION WATER}

\section{A. General Description}

Water for general service, fire protection and cooling water make-up is gathered from a spring fed stream and pumped to storage in a 50,000 galion redwood tank. The water is not treated and is considered nondrinkable. The dependable flow of the supply stream is estimated to be 5 to $6 \mathrm{gpm}$, but $1 \mathrm{~s}$ expected to be more than that auring most of the year. The elevation of the storage tank provides a static pressure on the water distribution system at the UnIt of approximately $100 \mathrm{psig}$. As the operation of the turbine-generator Unit will provide more condensate than the Ioss aue to evaporation at the cooling tower, it is expected that water will be drawn from storage ong for initial fill of the cooling water but not

system and the for make-up. The elevation of the intake is 1,922 fty, the elevation of the pump sump is $1,886 \mathrm{ft}$, and the elevation of the control polnt water surface in the storage tank is $2,138 \mathrm{ft}$.

B. Intake end Pump Sump

An Intake structure located approximately $950 \mathrm{ft} \not k$ north of the Unit aiverts water into a 6 in. asbestos concrete intake pipe.

The Intake pipe conducts the water down to the make-up water pump sump which is located near the northwest corner of the cooling tower. A channel is provided to permit draining water from the cooling tower basin to the pump sump if this becomes necessary. The pump sump is provided with an overflow which discharges into a stream downhill from the UnIt. A 2 in. Iine terminating at the intake works with a hydrant, is provided for cleaning and flushing the intake, This line is served from the Ine between the pumps and the storage tank. 
C. Make-up Water Pumps

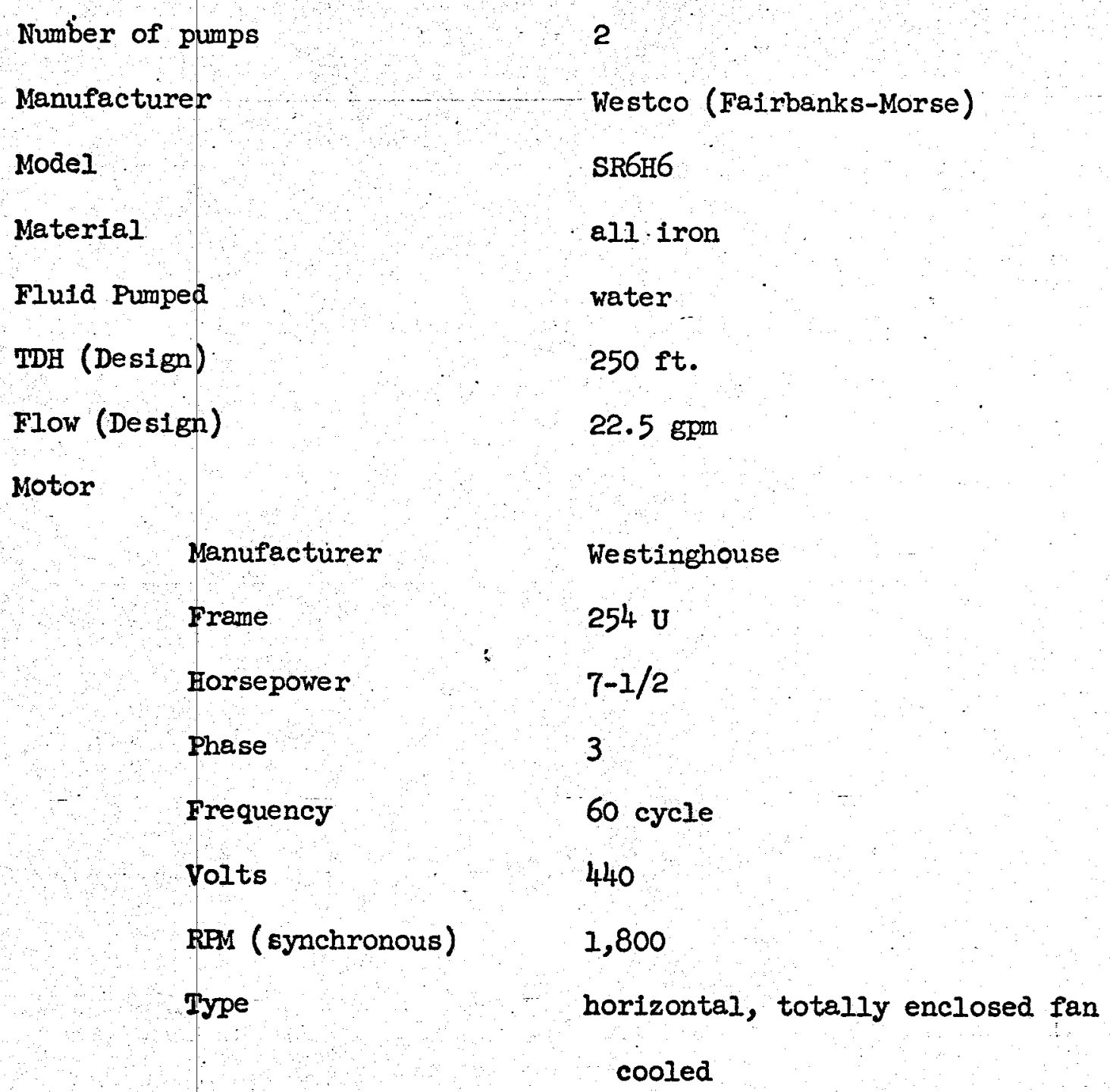

\section{Make-up Pump Motor Controls}

Selection is provided of "start", "stop", and "automatic" for each motor by a control switch located near the motor. No spring return is provided. If automatic operation is selected for either or both pumps starting and stopping will be initiated by the storage tank level float control switch, ILS-1. Note that LLS-1 and Its auxiliary relay IISX-1 are energized from the control circult of the 480 volt circuit breaker (52-14) for the make-up pump 3-1. If this control circuit is de-energized only water can be pumped by manual starting of pump 3-2. 
E. Water Storage Tank

The water storage tank is of 50,000 gallon capacity. It is constructed of redwood, and fitted with aluminum screen and screen fasteners. The 6 in. outlet pipe is of type 316 stainless steel. An aluminum float, filled with styroffoam, is provided to operate the make-up pump control switch (LLS-I) and the water tank low level alarm (IJA-I).

F. Water Distribution

The water pumps discharge through check valves into a distribution system. A tap line from the distribution loop conveys water to and from the storage tank. A sectionalizing valve is provided near the storage tank.

The distribution system is basically a 6 in. concrete asbestos pipeIine that 1oops around the Unit and the area provided for Units 4 and 5. Six sectionalizing valves are provided in the loop.

F Hive fire hose stations are located on short taps from the loop, and two additional fire hose stations are provided on a tap that extends along the northwest side of the switchyard.

Service water for a tollet, a washbasin and a service sink is taken from the distribution system. 
ELECTRICAL CONIROL SYSTEM

SECTION INDEX

1. General Description

2. Control Switchboard

3. Annunciator

Drawing Number

433131

045783
REFERENCES

Title

Arrangement of Electric Control and Relay Board

Bill of Material for Drawing 433131 


\section{ELECTRICAL CONTROL SYSTEM}

\section{(1) General Description}

The main control board is located on the south side of the building near the turbine end standard. With some exceptions the Unit is controlled from this board including Unit synchronization, $13.8 \mathrm{kv}$ generator air circuit breaker control, $60 \mathrm{kv}$ oil circuit breaker control, generator field control, and plant auxiliary control. Most of the Unit instrumentation is displayed on this board, including generator instruments, steam flow recorders, and the plant annunciator. Almost all of the plant protective relays are mounted on this board. The board is composed of five panels, a TurbineGenerator section, two Generator panels, a Station Service panel and a $60 \mathrm{kv}$ control panel. The board is fully enclosed, with an access door at each end. Copper wire, cable and bus conductors are tinned, and wherever practicable other copper parts are tinned orricoated to protect against corrosion due to hydrogen sulfide gas.

(2) Control Switchboard

Manufacturer

Purchase Order No. Specification No.

\section{(3) Annunciator}

\section{Manufacturer \\ Purchase Order No. Manufacturer's Type}

\author{
Western Switchboard Co. \\ $4 R-42454$ \\ 6887
}

\author{
Rochester Instrument Systems \\ $4 \mathrm{R}-42245$
}

AN 100

The main plant annunciator is mounted on a generator control panel of the main control switchboard. It is a forty-eight window system, eight rows high by six columns wide. Twenty-four indicators in the upper four row are set up to provide "first alarm" indication by showing red illumination of the first of that group to receive an alarm. The "first out" display will remain until reset through a separate "first out acknowledgement" push button, even if the alarm condition returns to normal. This feature is provided as an aid to diagnosis of trouble, as the first condition that causes a Unit trip is followed by a large number of subsequent alarms. 
Specification Number

Purchase Order Number

Manufacturer

Manufacturers Type
6889

$4 R-37523$

Westinghouse

15ODHP 500

General Description:

The generator switchgear is a two compartment, indoor metal-clad unit. One compartment contains the $13.8 \mathrm{kv}$ drawout type generator air circuit breaker and 3 current transformers. The other compartment contains three potential transformers and their fuses.

Bus

Bus current rating

Air clrcuit Breaker

Rated Voltage

Interrupting rating

Continuous rating

Momentary rating

4 second rating

Interrupting rating

Control

Current Transformers

Potential Transformers
Aluminum 1/2-in. $\times$ 4-in., 2 per phase 2,000 amperes

$13.8 \mathrm{kv}$

500 mva at rated voltage

2,000 amperes

40,000 amperes

25,000 amperes

21,000 amperes at rated voltage

125 volts $d-c$

$2,000 / 5$ amperes

$14,400 / 120$ volts 


\section{AUXILIARY POWER}

Section Index

A. Auxiliary Power System - General

B. Auxiliary Power Transformer

C. 480 Volt Switchgear

D. Motor Control Center

\section{References}

Drawing Number

Title

433102

433122

Record Number

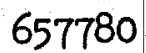

658220
Single Line Meter and Relay Diagram

Schematic Diagram, 120-208 Volt Station Service

Manufacturer's Drawings 480 Volt Switchgear

Manufacturer's Drawings 480 Volt Motor

Control Center 


\section{AUXILIARY POWER}

A. Auxiliary Power System-General

Electric power is used for the operation of Unit 3 at the following voltages:

(1) 480 volt, a-c, 3 phase, delta

(2) 120-208 volt, a-c, 3 phase, grounded $Y$

(3) 125 volt, d-c. (The d-c supply and use is described in a separate section).

The auxiliary power is supplied through a 3 phase 1,350 kva, $13.8 / 480$ volt auxiliary power transformer. The high voltage connection to the transformer is tapped directly to the $13.8 \mathrm{kv}$ bus between the generator alr circuit breaker and the main power transformer. Thus the source of auxiliary power, when the Unit is on the Iine, is the generator. However with the generator air circuit breaker $(252-3)$ open, power is available from the $60 \mathrm{kv}$ line by way of the main power transformer.

A metal enclosed bus connects the auxiliary transformer to the 480 volt switchgear assembly. No incoming circuit breaker is provided; an auxiliary power transformer primary overcurrent relay (25l-3), when picked up, will initiate trip of the Unit and the $60 \mathrm{kv}$ circuit breaker, completely deenergizing the primary winding of the auxiliary power transformer. The 480 volt switchgear serves cooling tower motors, the cooling tower supply pump motor, the condenser supply pump motor and the 480 volt motor control center. A 480 volt bus ground relay (64-3) provides an alarm only for 480 volt system ground.

The 480 volt motor control center serves motors up to 30 horsepower, power receptacles and the lighting transformer.

The lighting transformer is a 3 phase, $45 \mathrm{kva}, 480 / 120-$ 208 volt transformer supplying a 3 phase, 4 wire, grounded neutral lighting panel No. 1. The lighting panel supplies small auxiliary functions such as sump pumps, water heater, roof exhaust fans and instruments as well as lighting. It also supplies power to the station battery charger. 
B. AUXILIARY POWER TRANSFORMER

Number of Units

Specification Number

Purchase Order

Manufacturer

Rating

Phase

High Voltage

High Voltage Taps

Low Voltage

Tertiary

Connection

Exciting Current:

(C) 100\% voltage:

(Q 110\% voltage:

No Load Losses

Total Losses

Efficiency

Regulation

$$
\text { @ } 100 \% \mathrm{pf}
$$$$
\text { (@) 80\% pf }
$$

Oil

Weights

Core and coils

Tank and fittings

Oil

Total

Bushings

HV

LV

Impedance
1

6886

4R-'+2223

Kuhlman Electric Company

$1,200 / 1,350 \mathrm{kva}, 55 / 65 \mathrm{C}$ rise

3 phase

13,800 volts

$14,500-14,150-13,450-13,100$

480 volts

None

Delta-Delta

$0.6 \%$

$1.1 \%$

2,000 watts

16,000 watts

$98.68 \%$

$1.5 \%$

$6.09 \%$

350 gallons

6,000 Ibs.

2,200 lbs.

2,630 1bs.

10,830 Ibs.

Lapp 73531-B

Lapp 60026

$8.25 \%$ 
C. 480 VOIT SWITCHGEAR

Number of Units 1

Manufacturer General Electric Company

Manufacturer's Type AKD-5 Powermaster Swltchgear

Specification Number $\quad 6888$

Purchase Order 4R-37581

Bus Rating:

Momentary

50,000 amp

Continuous

1,600 amp, 40C ambient

Circuit Breaker cells:

600 amp frame $\quad 7$

1,600 amp frame 1

Circuit Breakers

AK2A25 6

AK2A50 1

Potential Transformers

$$
\begin{aligned}
& \text { 5, GE type JVP, } \\
& 300 \text { va } 65 \mathrm{C} \text { ambient } \\
& 480 / 120 \text { volt }
\end{aligned}
$$

NOTE: Metal enclosed bus to connect the 480 volt switchgear to the auxiliary power transformer is supplied on the same purchase as the switchgear. 
D 480 VOLT MOTOR CONTROL CENTER

Number of Units 1

Manufacturer

Specification Number

Cutler Hammer

Purchase Order

6890

$4 R-42225$

Bus Rating

Momentary

50,000 amps

Continuous

600 amp (minimum)

Motor Starter Units

NEMA Size 1

10

NEMA Size 2

3

NEMA Size 3

1

Circuit Breakers (100 ampere)

6 
Section Index

A. 125 Volt D-C System - General

B. 125 Volt D-C Supply

C. Alarms and Control

D. Emergency Lighting Supply

\section{References}

Drawing

\section{Title}

433122

Schematic Diagram, $120 / 208$ Volt Station Service and 125 Volt D-C System

Record Number

657.254
Title

Instructions, Battery Charger 


\section{A. 125 Volt D-C System - General}

The station 125 volt d-c system serves the following equipment and functions:

1. Control power for relays, solenoids, exciter regulation, circuit breaker and switchgear.

2. Annunciator supplies.

3. Main generator field flashing.

4. Emergency lighting.

5. Standby pump motor supply

(a) Standby lubricating oil pump

(b) Standby seal oil pump

(c) Standby lube oil vapor exhaust pump

B. 125 Volt D-C Supply

The direct current supply consists of a 60 cell lead-acid battery. Each cell is in a plastic jar with sealed cover.

The battery is an Exide, Type 1-6 FMP-11. A battery charger is provided, Model 1-US-130-1-25. Power supply to the battery charger is 208 volts a-c, taken from the $120 / 208$ volt distribution panel.

C. Alarms and Control

A low voltage relay ( $27 \mathrm{BC})$, which is a part of the battery charger, provides an alarm only for low charger voltage.

However low battery voltage is potentlally hazardous to the Unit as many vital control circuits are d-c. As the Unit operates unattended, Unit trip and lockout are Initiated by the operation of a battery 10 woltage relay $(80-3)$. 
A battery system ground detector is provided, and a battery system ground relay provides an alarm. The battery ground detector system is open circuited by operation of the generator field flashing pushbutton. The purpose is to prevent interaction between the generator field ground detector system and the battery ground detector system.

\section{Emergency Lighting Supply}

A d-c circuit is provided for emergency lighting service. The double throw two pole transfer switch is manually operated. Care should be taken that the emergency lights are not left drawing power from the battery when not necessary. 


\begin{tabular}{|c|c|c|c|}
\hline $\begin{array}{l}\text { Spec. } \\
\text { No. }\end{array}$ & Description & $\begin{array}{c}\text { Contract } \\
\text { Number } \\
\end{array}$ & $\begin{array}{c}\begin{array}{c}\text { Manufacturer or } \\
\text { Contractor }\end{array} \\
\end{array}$ \\
\hline 6871 & F\&D Turbine Generator Unit & $4 R-34093$ & Elliott Co. \\
\hline 6872 & F\&D Barometric Condenser & $4 R-34192$ & Elliott Co. \\
\hline 6874 & Construction of cooling Tower & $22-414-64$ & Fluor Products \\
\hline 6875 & F\&D Circulating Water Pumps & $4 R-37524$ & Peerless Pumps \\
\hline 6876 & & & \\
\hline 6877 & & & \\
\hline 6878 & $\begin{array}{l}\text { F\&D Turbine Steam Exhaust Duct } \\
\text { and Expansion Joints }\end{array}$ & $4 R-42549$ & $\begin{array}{l}\text { Saracco Tank \& } \\
\text { Mfg. Co. }\end{array}$ \\
\hline 6879 & F\&aD Steam Power Plant Piping & $4 R-42601$ & Pacific Pipe \\
\hline 6880 & F\&D Lubricating 0il Tank & $4 R-51031$ & Conlin \& Roberts \\
\hline 6881 & F\&d Butterfly Valves & $4 R-42252$ & Keystone Valve Corp. \\
\hline 6882 & F\&D Air compressor & $4 R-37462$ & Davey Compressor Co. \\
\hline 6883 & & & \\
\hline 6884 & & & \\
\hline 6885 & F\&D Main Transformer Bank & $4 R-83903$ & General Electric \\
\hline 6886 & $\begin{array}{l}\text { Fed Station Service Transformer } \\
\text { Bank }\end{array}$ & $4 R-42223$ & Kuhlman Electric Co. \\
\hline 6887 & F\&D Control and Relay Boerd & $4 R-42454$ & $\begin{array}{l}\text { Western Switchboard } \\
\text { Co, }\end{array}$ \\
\hline 6888 & F\&D 480 volt Switchgear & $4 \mathrm{R}-37581$ & General Electric \\
\hline 6889 & F\&ED Generator Switchgear & $4 R-37523$ & Westinghouse \\
\hline 6890 & F\&D Motor Control center & $4 R-42225$ & cutler-Hammer \\
\hline 6891 & Grading \& Paving & & \\
\hline
\end{tabular}




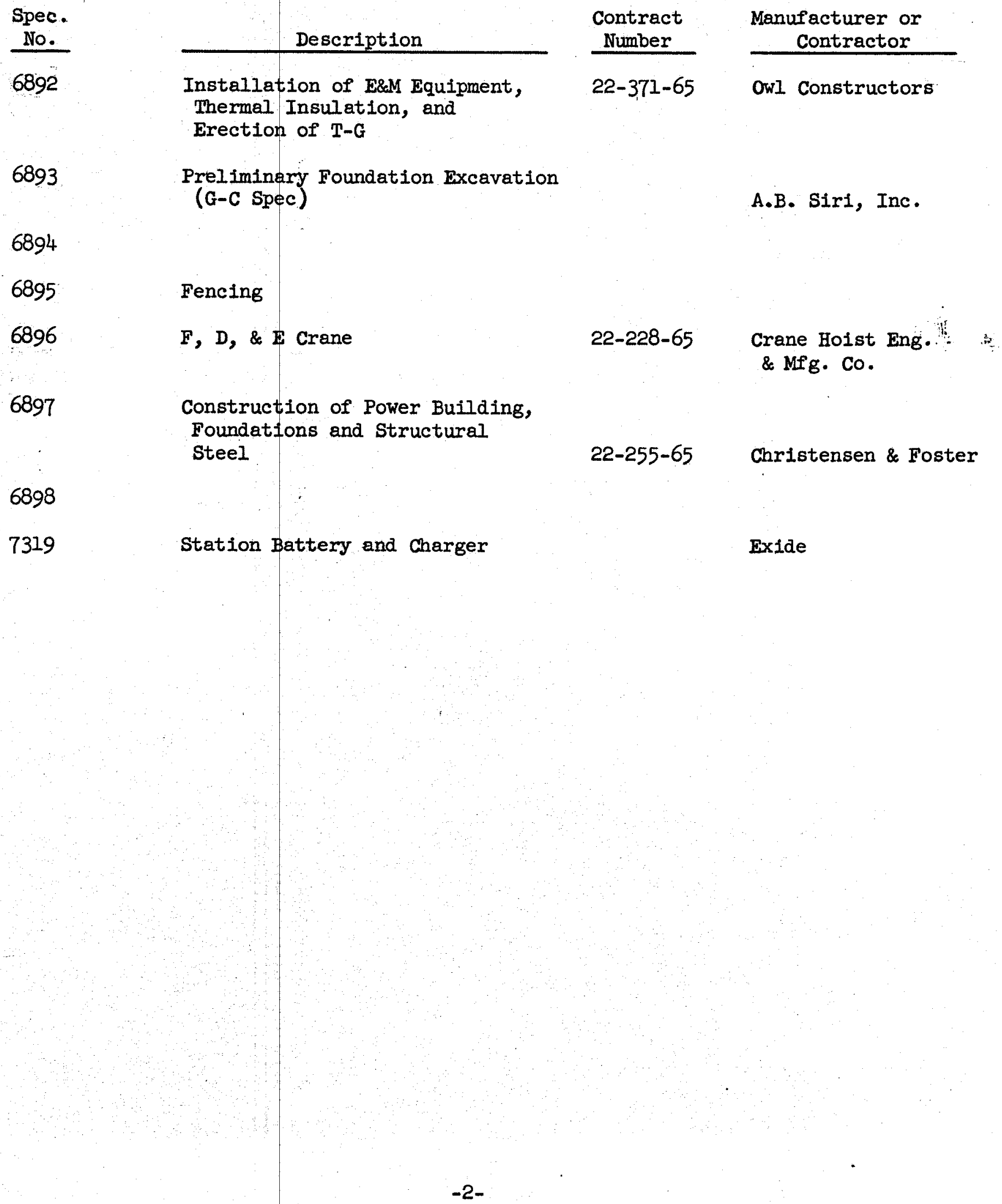


Civil Drawings

Rough Grading Plan

433161

Grading and General Layout

433162

Water Supply and Fire Protection System

433163

Water Supply Intake

433164

Storm and Sanitary Sewers

433165

General Utilities

433166

Circulating Water System Concrete Outline

433167

Circulating Water System, Reinforcing \& Details

433168

Foundations for Transformers, Switchyard, and Miscellaneous Structures

433169

Waste Water Disposa1 System, Sedimentation Basin

433170

Waste Water Disposal System, Piping and Details

433171

Fencing and Paving, Plan and Details

433172

Water Supply Tank Requirements

433173

Circulating Water System, Piping Layout and Details

433174

Circulating Water System, Anchor Liners

433175

Hydrogen Bottle Racks, Manifold Cabinet \& Misc. Details

433176

Structura1 Drawings

Concrete Outline, P1an at Elev. $1896 \mathrm{ft}-0$ in.

433178

Concrete Outline, Plan at Elev. $1881 \mathrm{ft}-0$ in. and Sections

Concrete Outline Sections N1, N2, N4, N5

433179

Concrete Out1ine Sections W2, W3, N3, N6

433180

433181

Reinforcing Plan at Elev. $1896 \mathrm{ft}-0$ in. and Details

433182

Reinforcing Plan at Elev, $1881 \mathrm{ft}-0$ in. and Sections

433183

Reinforcing Sections

433184

Cooling Tower, Foundation and Details

433186

Power Building Superstructure - Steel Framing

433187

Power Building Superstructure - Steel Framing Details

433188

Plans and Elevation Tower for Barometric Condensers

433189

Details of Tower for Barometric Condensers

433190

20 Ton Crane Requirements

046007

Architectura 1 Drawings

First F1oor Plan

433701

Basement Floor Plan

433702

Elevations and Sections

433703

Exterior Wal1 Sections

433704

Roof Plan and Details

433705

Miscellaneous Stee 1

Miscellaneous Steel in Building

433706

Ladder Schedule ahd Details

433707

Storage and Toilet Rooms

433708

433709

Ventilation and Electrical

433710

Plumbing

433711

Perspective

433712 
Genera1 Layout

432591

Equipment Location

Plan at: Basement, Operating Floor, Condenser Platform

57431

Section $A-A$ and $B-B$

57432

Section C-C and D-D

Piping and Mechanical

Area A

P1an Below Elev. $1895 \mathrm{ft}-0$ in.

57435

Plan Below Elev. $1920 \mathrm{ft}-0$ in.

57436

Section A-1, A-2

57437

Section A-3, A-4, A-5

57438

Miscellaneous Sections

57439

Area B

P1an Below Elev. 1882, 1895, 1920,1958 , and Sect. B-3 \& B-4

57441

Section B-1, B-2

57442

Miscellaneous Sections

57443

Cooling Tower - Plan and Sect.

57445

Piping Layout - Main Steam

57446

P\&M General Notes, References

045599

Miscellaneous Piping

Drain Funnels

100871

Lube 0i1 Storage Tank

SK-2676-33

Sleeves and Spools

328738

Insulating F lange Schedule

214441

Piping and Instrumentation Diagrams

P.\&I.D. Legend

100872

P.\&I.D. Steam and Condensate

432594

P.\&I.D. Cooling Water

432595

P.\&I.D. Lubricating 011

432596

P.\&I.D. Miscellaneous: Service Systems

432597

Heat Balance Diagram

214443

Line Designation Table

100881

Instrument Specifications

Pressure

100873

Temperature

100874

Flow and Leve 1

100875

Control Valves

100876

Electrical

100877

Steam Traps

100878

Relief Valves

100879

Miscellaneous Instruments

100880 
Drawing List (cont'd)

Instrument Piping Standards

Index of Instrument Symbols $\quad 045581$

Instrument Pipe Line Take-off Conn. $\quad 045582$

Main Steam Sample Nozzle

045584

Steam Trap Installation

045585

Pressure (P\&PX) Installation:

045586

Pressure Gage and Sample Conn. at

Pump Discharge

045587

Steam Flow and Press. Recording Inst.

045588

Feed Lines Flow Test (Pitot Tube) Inst. 045589

Vacuum Duct Level Control

045590

Water Storage-Tank Leve1 Switch Inst. 045591

Hydrogen Coolers Outlet Temperature • . . 045592

Exhaust Pressure Instrument Inst. 045593

Main Steam Pressure and Temp. Recorder 045594

Sump Pump Control and Alarm 045595

Requirements for $\mathrm{CO}_{2}$ Bottle Rack

045598

General Notes and References for Pipe

Hangers \& Supports.

045601

Details of Pipe Hanger No. 101.

045602

Details of Pipe Hanger No. 102

045603

Details of Pipe Hanger No. 103

045604

Details of Pipe Hanger No. 104

045605

Details of Pipe Hanger No. 105

045606

Details of Pipe Hanger No. 106

045607

Details of Pipe Hanger No. 107

045608

Details of Pipe Hanger No. 108

045609

Details of Pipe Hanger No. 109

045610

Details of Pipe Hanger No. 110

045611

Details of Main Steam Pipe Hanger No. 301

045612

Support Shoe \& Load Flange for

Main Steam Hanger No. 301

045613

Details of Main Steam Pipe Hanger No. 302

045614

Details of Main Steam Pipe Hanger No. 303

045615

Details of Main Steam Pipe Hanger No. 304

045616

Details of Main Steam Pipe Hanger No. 305

045617

Support Shoe \& Base Plate Detalls of

Hangers No. 303, 304, 305

045618

Details of Main Steam Pipe Hanger No. 306

045619

Details of Pipe Hanger Steel Attachment No. 1

045621

Details of Pipe Hanger No. 111

045623

Details of Pipe Hanger No. 112

045624

Details of Pipe Hanger No. 113

045625

Details of Pipe Hanger No. 114

045626

Details of Pipe Hanger No. 115

045627

Detal1s of Pipe Hanger No. 116

045628

Details of Pipe Hanger No. 117

045629

Details of Pipe Hanger No. 118

045630

Details of Pipe Hanger No. 119

046271

Details of Pipe Hanger No. 120

046272

Details of Pipe Hanger No. 121

046273

Details of Pipe Hanger No. 122

046274

Details: of Pipe Hanger No. 123

046275 
Drawing List (cond't) 
Electrical Drawings

Single Line Diagrams

S.L. Diag. Unit 3

433101

S.L. M.\&.R. Diag. Unit $3 \quad 433102$

Function Diagram Turbine-Genèrator Protection 433105

System Phasing and Syn. Pot...Diagram

433106

Main Unit Schematic Diagrams

Schematic M.\&R. Gen. Transformer, OCB $\quad 433107$

Schematic Diagram Turbine Contro1 433110

Schematic Diagram Gen. Control (Sh. 1) 433111

Schematic Diagram Gen. Contro1 (Sh. 2) 433112

Schematic Diagram Sea1 Oil PPs \& $\mathrm{H}_{2}$ Control $\quad 433114$

Schematic Diagram Excitation - Regulation 433115

Schematic Diagram Turning Gear Motors 433116

Schematic Diagram Cooling Water Pumps 433117

Schematic Diagram Lube 0i1 Pumps 433118

Schematic Diagram Miscellaneous Motors 433119

Schematic Diagram 60 kv OCB 433120

Station Electrical Schematic Diagrams

Schematic Diagram Main \& Aux. Transformers 433121

Schematic Diagram 120/208 V. Sta. Serv. \& 125 vdc 433122

Schematic Diagram Annunciator System $\quad 433126$

Schematic Diagram Instrumentation $\quad 433128$

Wiring Diagrams, Terminal Boxes 4433129

Arrangement of Control and Relay Board 433131

Arrangement of Main and Auxiliary Transformers $\quad 433133$

Air Switch Requirements for $60 \mathrm{kv}$ Switch and Bus 433135

Arrangement $60 \mathrm{kv} \mathrm{Switch}$ and Bus Structure $\quad 433136$

Electrica1 Arrangement of Cooling Tower 433137

Steel Requirements $60 \mathrm{kv}$ Switch and Bus $\quad 214837$

Cable Trays and Conduit Layouts

Arrangement of Conduits, Outdoors

433139

Arrangement of Embedded Conduits and Grounds-Power Building

433140

Cable Tray and Conduit Layout. Power

Building Basement

433141

Cable Tray and Conduit Layout

P1an Above Main Floor

Cable Tray and Conduit Layout Sections $\quad 433143$

Conduit Section and Details

433144

Conduit and Tray Schedules

Tray Schedule

045771

Conduit Schedule - Power Building $\quad 045772$

Conduit Schedule - Switchyard

045773 
Electrical Drawing List (cont'd)

Description of Drawing

Circuit Schedules

Circuit Schedule - Turbine Generator

Excitation and Regulation

Circuit Schedule - 480 Volt

Circuit Schedule - 125 Volt DC

Circuit Schedule - Annunciator

Circuit Schedule - Lighting \& Miscellaneous

Grounding Layouts

General Arrangement of Sta. \& Fence Gnd.

Lighting Layouts

Lighting Layout Power Building

Bill of Material

Control and Relay Boards

Arrangement of Main and Auxiliary Transformers

Power Control Wire and Cable

Te1. Thermo. and Miscellaneous Wire

Grounding Materials

Miscellaneous Equipment

Arrangement $60 \mathrm{kv}$ Switch and Bus Str.

Cable Tray and Conduit Layout, Power Building Basement

Miscellaneous

Typical Details - Conduit, Trays, Miscellaneous General Notes and Symbols, Trays and Conduits Ground Symbols - Notes - Details Typical Mounting Details - Miscellaneous Lighting Fixtures
Drawing Number

045776

045777

045778

045779

045780

433146

433149

045783

045784

045785

045786

045787

045788

045789

045795

045790

045791

045792

045794 
P\&I DRAWINGS 


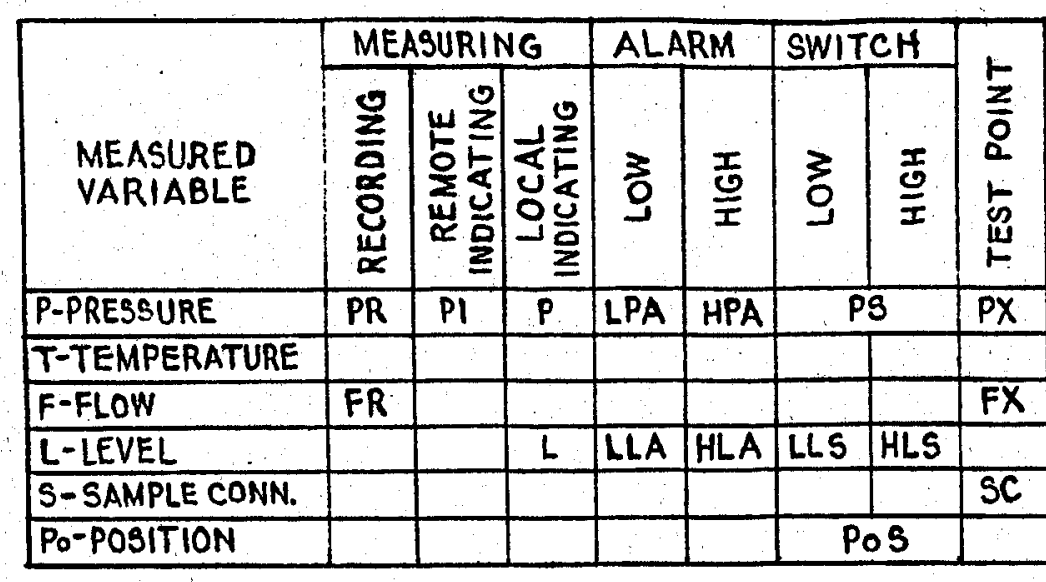

APS -AUTOMATIC PUMP START SSV -SOLENOID STOP VALVE

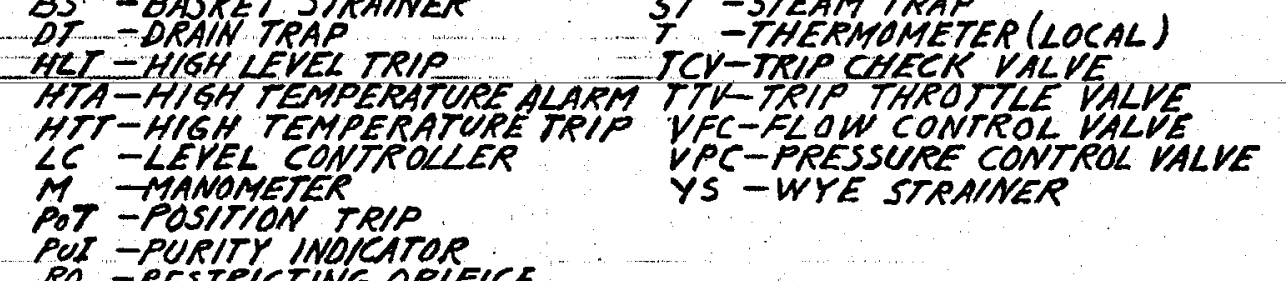

POT EPOSITION TRIP.
PUT -PURITY INOICATOR.

PO -RESTRICTING ORIFICE
RV DELIET VALVE

LINE SYMBOLS

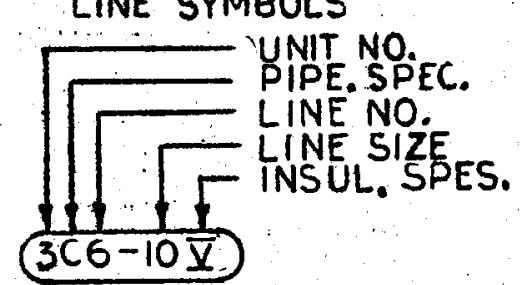

VALVE SYMBOLS

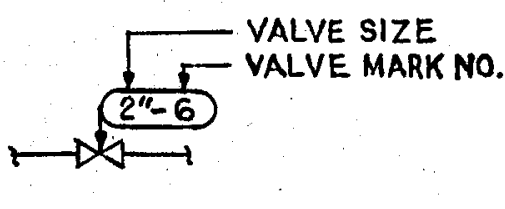

TYPICAL INSTRUMENT SYMBOLS

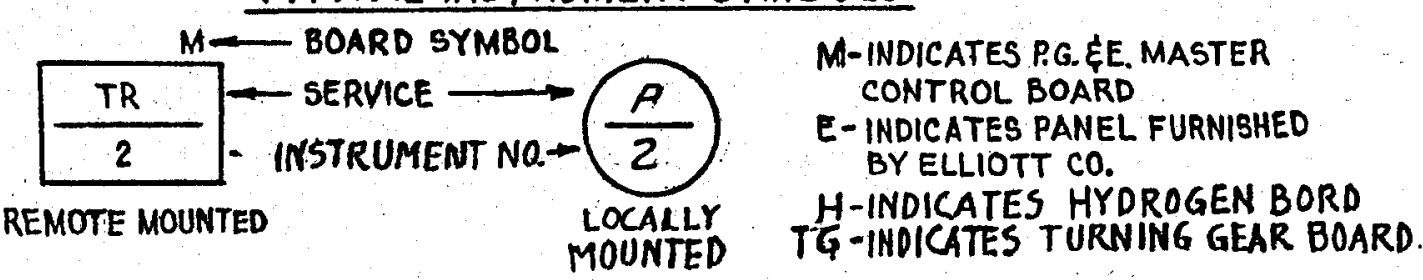

MISCELLANEOUS

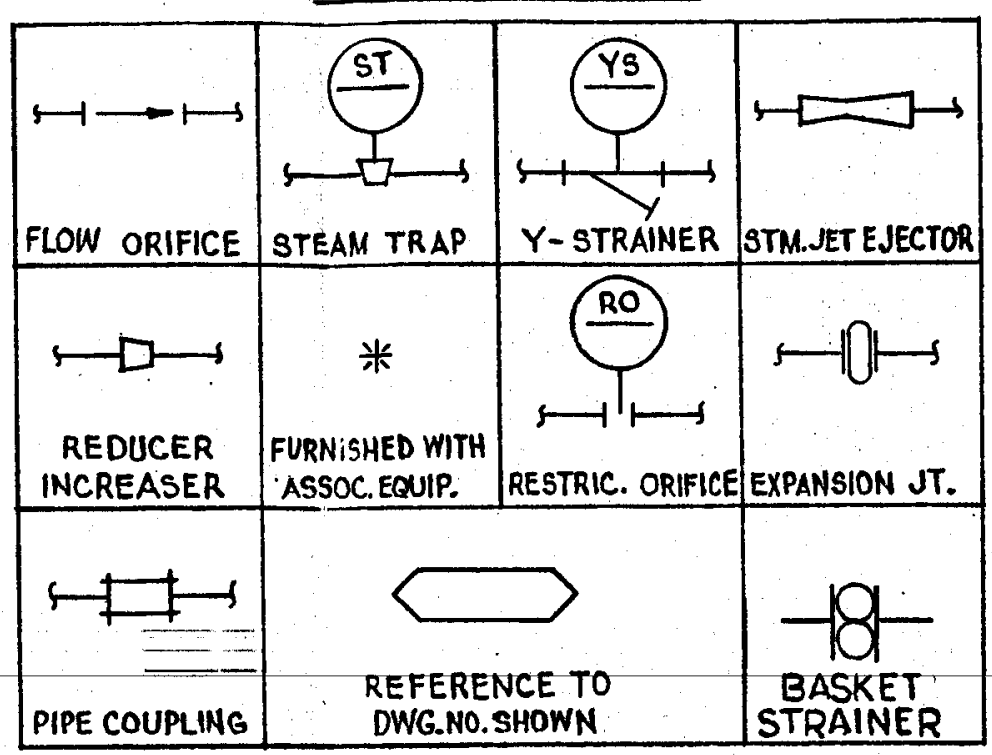

PRIMARY LIMES

SECONDARY LNES - - - -

INSTRUMENTELECTKIC LEAD - $-\cdots$

INSTRUMENT CAPILLARY TUBING $-\cdots-\cdots$
VALVE SYMBOLS

\begin{tabular}{|c|c|c|}
\hline & $10 \mathrm{CK}$ & VALVES \\
\hline & OPEN & CLOSED \\
\hline & L.O. $\rightarrow \infty$ & L.C. $\rightarrow-1$ \\
\hline & NORMAL & POSITION \\
\hline CONTROL & OPEN & CLOSED \\
\hline & $\rightarrow \infty$ & $\rightarrow 4$ \\
\hline & & FLOW \\
\hline$\rightarrow-$ & $\rightarrow \infty$ & $-a$ \\
\hline GATE & GLOBE & CHECK \\
\hline$-1,1$ & & $\rightarrow W 1$ \\
\hline BUTTERFLY & ANGLE & NEEDLE \\
\hline- & 㧱 & \\
\hline DUG & 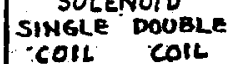 & 3 WAY VALY \\
\hline
\end{tabular}



\section{REFERENCE DRAWINGS}

\begin{tabular}{|l|l|}
\hline NUMBER & \multicolumn{1}{|c|}{ TITLE } \\
\hline 432594 & STEAM E CONDENSATE \\
\hline 432595 & COOLING WATER \\
\hline 432596 & LUBRICATING OIL \\
\hline 4332597 & MISC. SERVICE SYSTEMS \\
\hline
\end{tabular}

PIPING AND INSTRUMENT DIAGRAM

LEGEND

UNIT NO. 3

THE GEYSERS POWER PLANT

DEPARTMENT OF ENGINEERING

PACIFIC GAS AND ELECTRIC COMPANY

SAN FRANCISCOO, CALIFORNIA

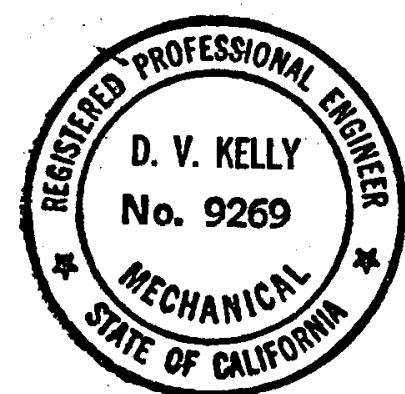

MORTH BAY DNVSION

BILL OF MATERIAL

DRAWING LIST

SUPERSEDES

SUPERSEDED BY

SHEET NO.

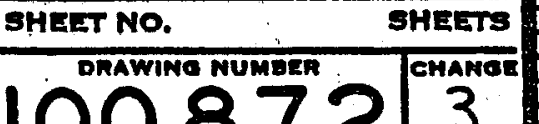

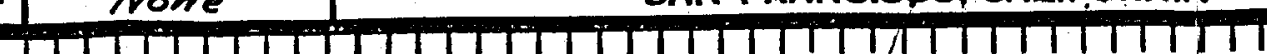




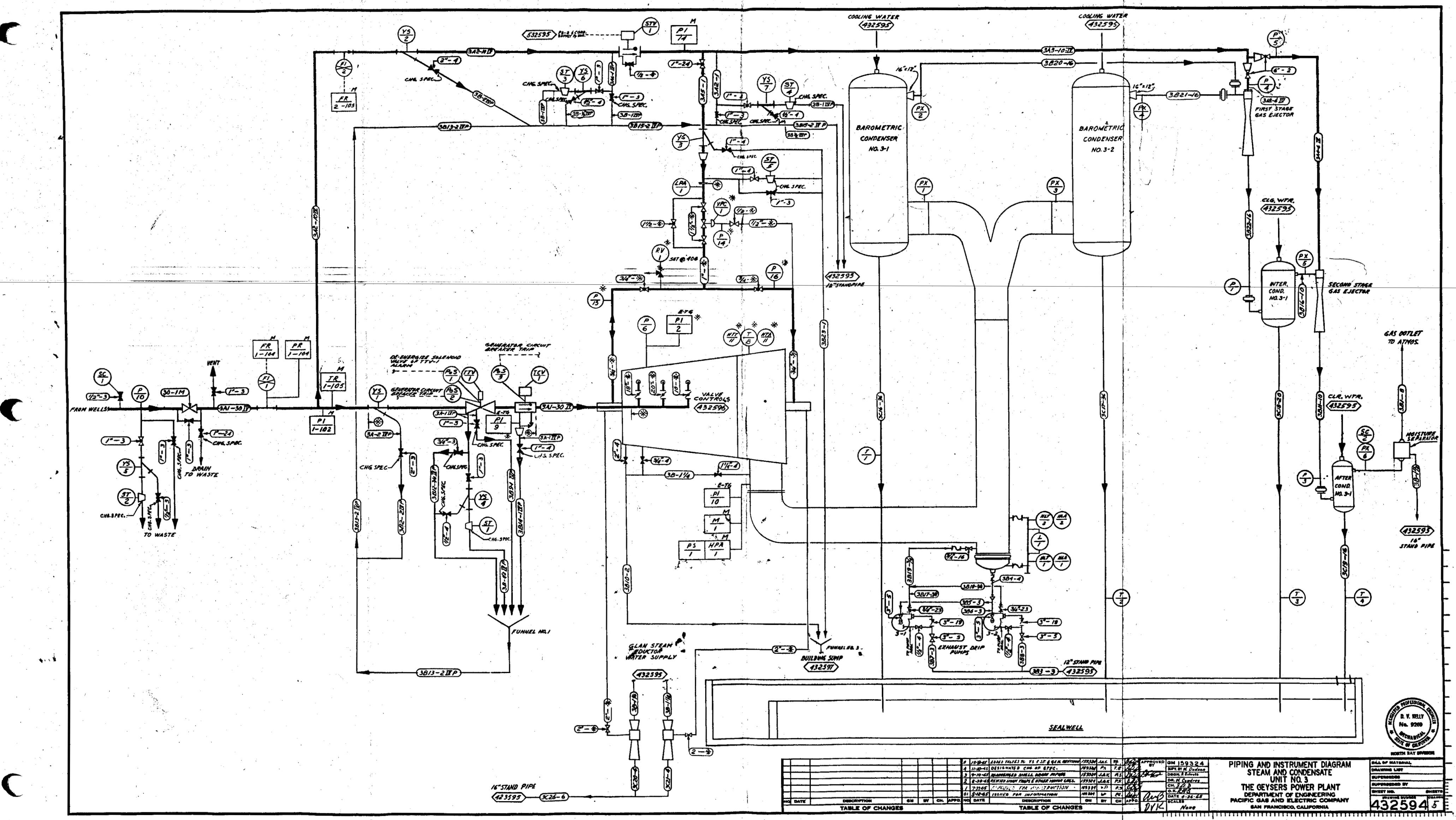




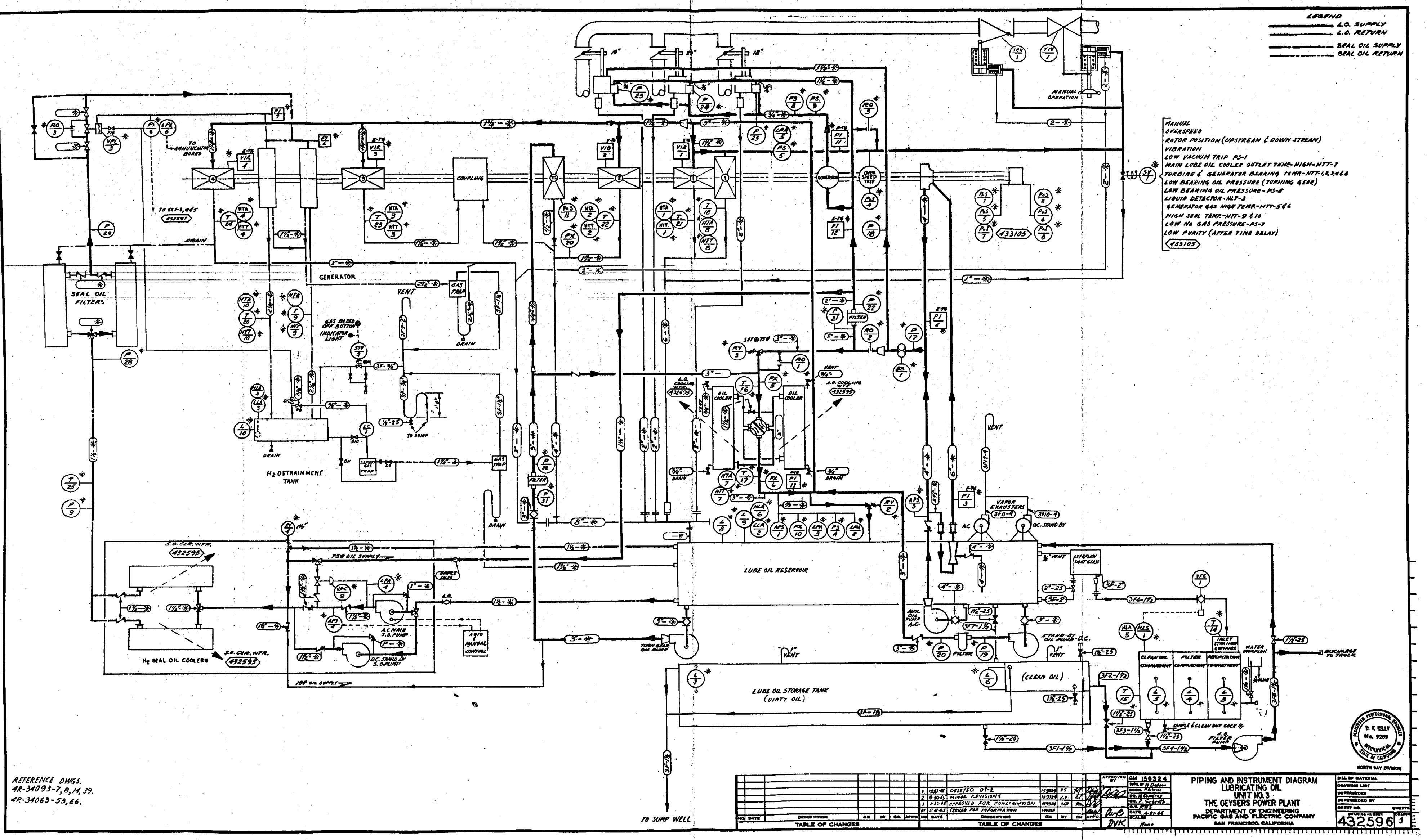




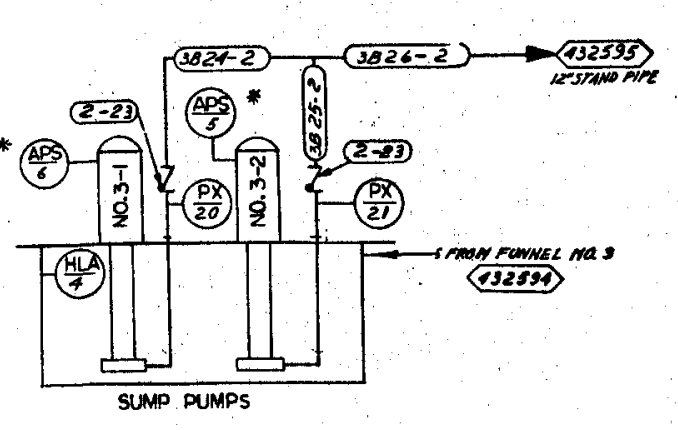

(119)
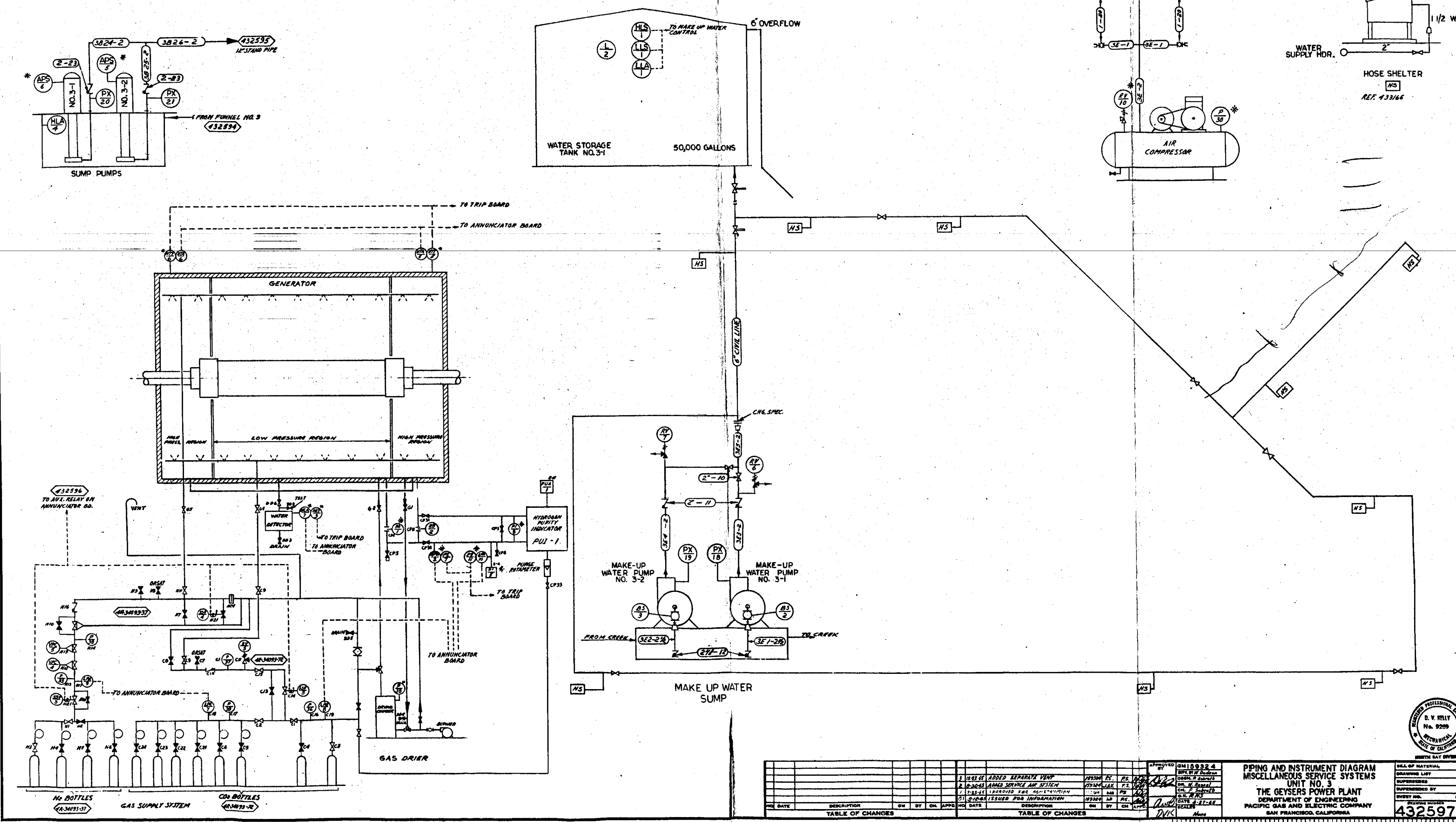


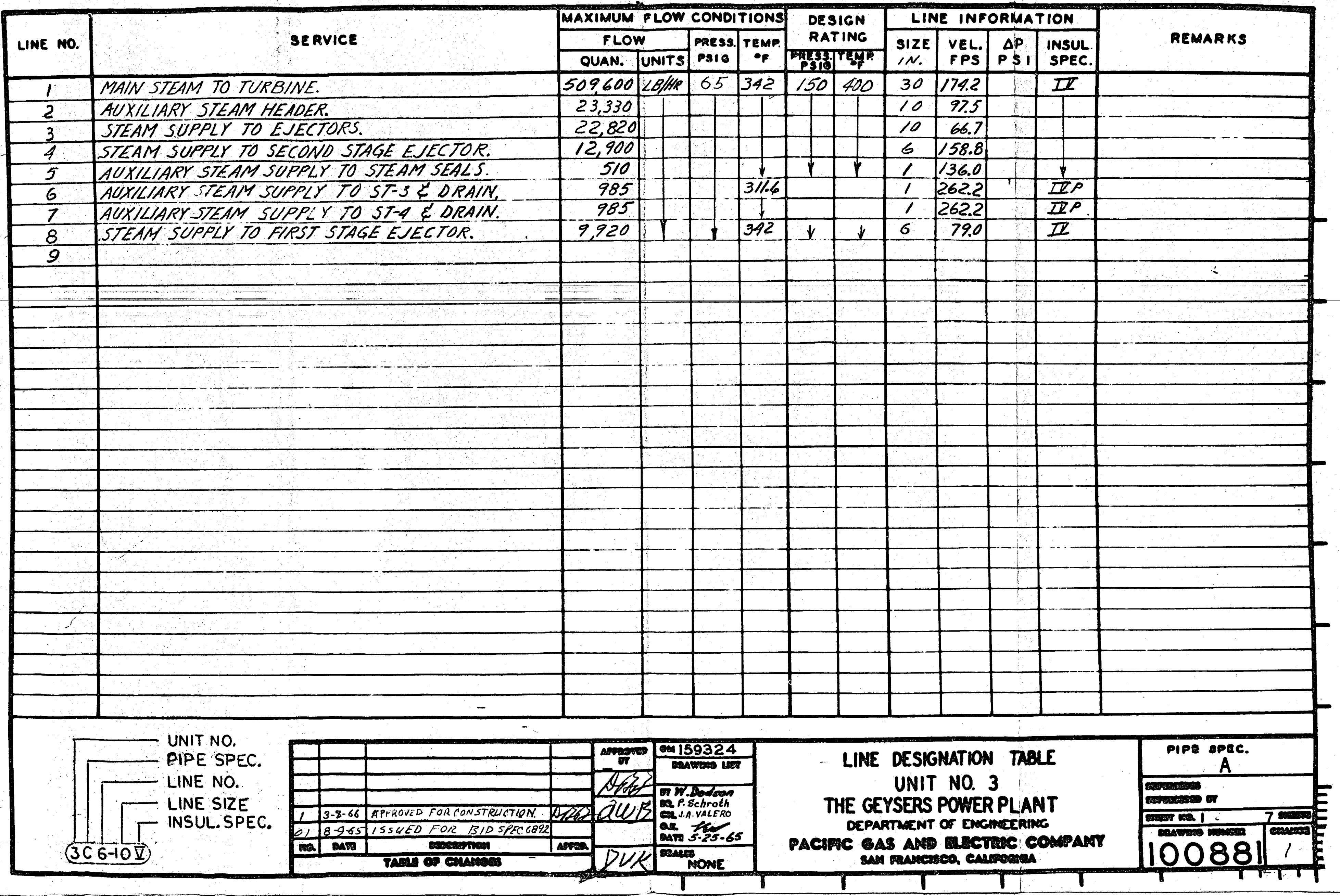




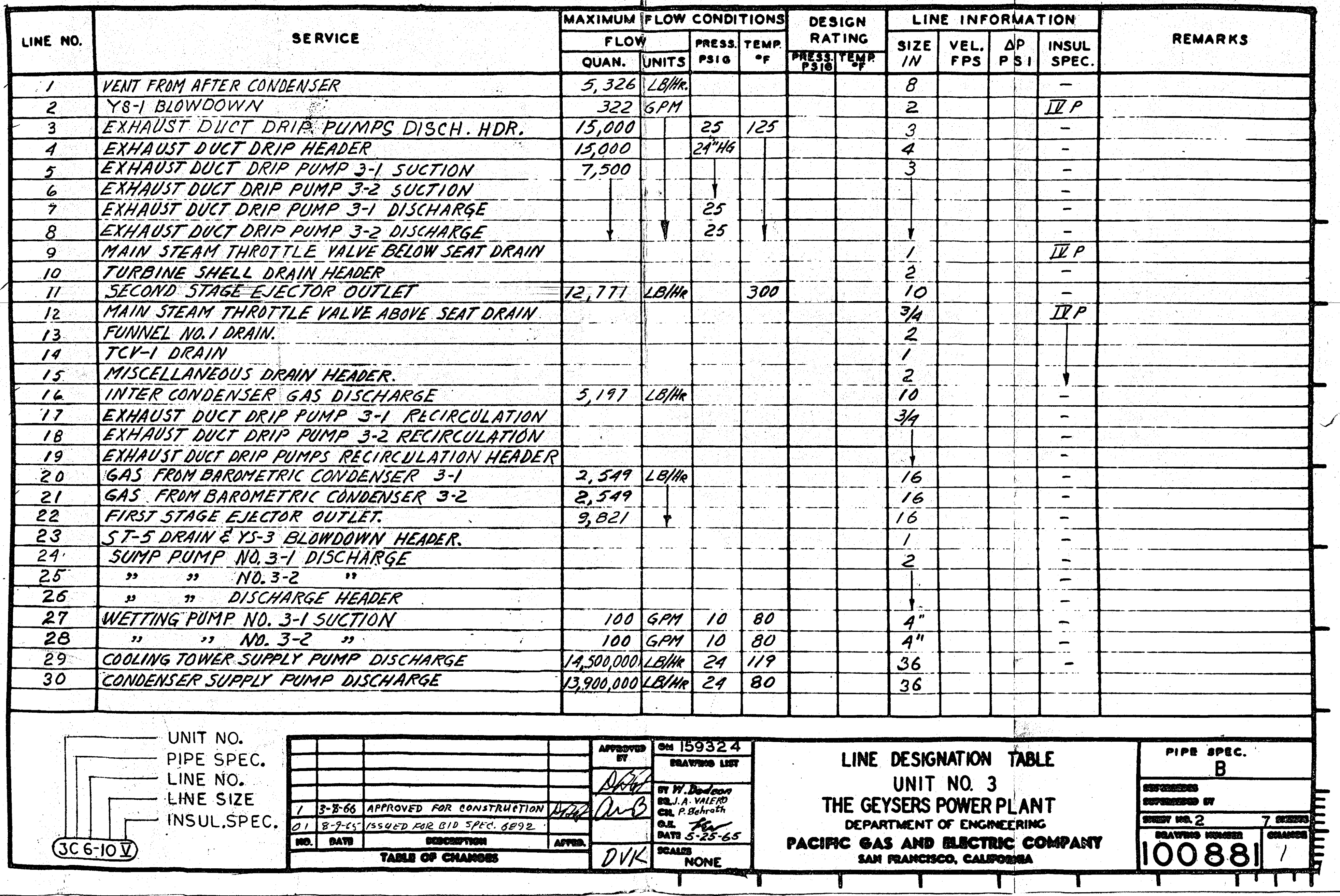




\begin{tabular}{|c|c|c|c|c|c|c|c|c|c|c|c|c|c|c|c|}
\hline \multirow{3}{*}{ LINE NO. } & \multirow{3}{*}{\multicolumn{2}{|c|}{ SERVICE }} & \multicolumn{4}{|c|}{ MAXIMUM FLOW CONDITIONS } & \multirow{2}{*}{\multicolumn{2}{|c|}{$\begin{array}{l}\text { DESIGN } \\
\text { RATING }\end{array}$}} & \multicolumn{4}{|c|}{ LINE INFORMATION } & \multirow{3}{*}{\multicolumn{2}{|c|}{ REMARKS }} & \\
\hline & & & \multicolumn{2}{|l|}{ FLOW } & \multirow{2}{*}{\begin{tabular}{|c|}
$\begin{array}{c}\text { paess } \\
\text { psio }\end{array}$ \\
\end{tabular}} & \multirow{2}{*}{$\begin{array}{c}\text { TEMP. } \\
\text { OF }\end{array}$} & & & \multirow{2}{*}{$\begin{array}{l}\text { SIZE } \\
\text { IN. } \\
\end{array}$} & \multirow{2}{*}{$\begin{array}{l}\text { VEL. } \\
\text { FPS }\end{array}$} & \multirow{2}{*}{$\begin{array}{l}\Delta p \\
P S \text { I }\end{array}$} & \multirow{2}{*}{$\begin{array}{l}\text { INSUL } \\
\text { SPEC. }\end{array}$} & & & \\
\hline & & & OUAN. 1 & UNITS & & & \multicolumn{2}{|c|}{ 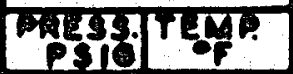 } & & & & & & & \\
\hline 1 & \multicolumn{2}{|c|}{ CONDENSER SUPPLY PUMP DISCHARGE. } & \multicolumn{2}{|c|}{$13,900,000 / \mathrm{kB} / \mathrm{HR}$} & 50 & \multirow[t]{2}{*}{80} & & & 36 & & & & & & \\
\hline 2 & COOLING WATER TOHE COI & ILCOOLERS E TO INTER\&AFTER CONED & \multicolumn{2}{|l|}{$1,07,000$} & & & & & 14 & & & & & & \\
\hline 3 & HYDROGEN COOLING $n$ & WATER SUPPLY HEADER. & 250,000 & & & 1 & & & 6 & & & & & & \\
\hline 4 & COOLING WATER FROM & I $\angle U B E$ OIL COOLER. & 67,500 & & & 86 & & & 4 & & & & & & \\
\hline 5 & COOLING WATER TO & $\angle U B E O / L$ COOLERS. & $67,500 \|$ & & & 80 & & & 4 & & & & & & \\
\hline 6 & COOLING WATER FR & OM AYDROGEN COOLER. & 250,000 & & & 87 & & & 6 & & & & & & \\
\hline 7 & CIRC. WATER SUPPLY TOE & BAROMETRIC CONDENSERS. & $12,816,500$ & & & 80 & & & 36 & & & & & & \\
\hline 8 & & NTERCONDENSER. & 417,500 & & & & - & & 8 & & & & & & \\
\hline 9 & & AFTERCONDENSER. & 336,000 & & & & 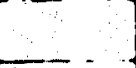 & & 8 & & & & & & \\
\hline 10 & $\sqrt{4}$ & TYOROGEN SEAL OIL COOLERS. & 12,500 & & & & & & $\pi / 2$ & & & & & & \\
\hline 11 & FEED 70600 & OLING TOWER CELL NO.I. & $4,833,333$ & & & 119 & & & 24 & & & & & & \\
\hline 12 & 11 & NO.2. & & & & & & & 24 & & & & & & \\
\hline$\sqrt{3}$ & 11 & 11 No. ${ }^{3}$. & & & & 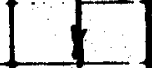 & $\therefore$ & & 24 & & & & & & \\
\hline 14 & SUPPLY TO & BAROMETRIC CONDENSER NO. $3 . \%$ & $6,408,250$ & & & 80 & & & 24 & & & & & & \\
\hline 15 & $-1-1$ & $1-1 \quad N 0.3-2$ & $6,408,250$ & & & 80 & $\ldots$ & & 24 & & & & & & \\
\hline 16 & DORIPS FROM BAROME & TRRIC CONDENSER $3-1$ & $6,653,37$ & & $3.75 \%$ & 119.8 & & & 36 & & & & & & \\
\hline 17 & DRIPS FROM BAROME & ETRIC CONDENSER $3-2$. & $6,653,371$ & & $3.75 \%$ & $1 / 9.8$ & & 4 & 36 & & & & & & \\
\hline 18 & DRIPS FROM INTERCC & ONDENSER $3-1$ & 126,821 & & $3.5-2854$ & 109 & & & 20 & & & & & & \\
\hline 19 & DRIPS FROM AFTER & CONOENSER $3 \%$ & 398,771 & & HGABS & 120 & & & 16 & & & & & & \\
\hline 20 & GLAND STEAM EDUCTO & RO NO, 3-1 EXHAUST. & $25,133.5$ & & + & 85 & & & 4 & & & & & & \\
\hline 21 & 11,1 & No.3-2 1 & $25,133.5$ & $4-1$ & & 85 & & & 4 & & & & & & \\
\hline $22 *$ & GLAND SEAL EOUCTORE WE & ETTING SUPPLY PUMP NO 3-1 DISCH. & 100 & GPM & & 80 & & & 3 & & & & & & \\
\hline $23 *$ & $1 \square \quad \square$. & \begin{tabular}{|l|l|} 
& $N 0.3-2$ \\
\end{tabular} & & & .. & I. & - & & 3 & - & & & & & \\
\hline $24 *$ & $1+1$ & $1+1$ DISCH.HEADER & 1 & 1 & & 1 & & & 3 & & & & & & \\
\hline 25 & COOLING TOWER WETTII & NG LINE & & & & & & & 3 & & & & & & \\
\hline 26 & GLAND STEAM EDUCTC & OR EXHAUST HEADER. & 50,267 & $\angle B / \operatorname{lm}$ & & 85 & & & 6 & & & & & & \\
\hline 27 & COOLING WATER TO HYL & DROGEN COOLER $3-1$ & 62,500 & & & 80 & & & 3 & & & & & & \\
\hline 28 & COOLING WATER TO HRD & DROGEN COOLER $3-2$. & & & & & & & 3 & & & & & & \\
\hline 29 & COOLING WATER TO HTO & OROGEN COOLER $3-3$. & & & & & & & 3 & & & & & & \\
\hline 30 & COOLING WATER TO AYDD & ROGEN COOLER $3-4$. & & 1 & & 1 & & & 3 & & & & & & \\
\hline & & & & & & & & & & & & & & & \\
\hline & & & & & & & & & & & & & & & \\
\hline & - PIPE SPEC. & & 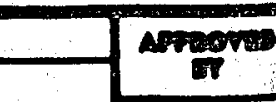 & & $\frac{59324}{100}$ & & & LINE & DESIG & IATHOA & TAB & & PIPe spec. & & \\
\hline & LINE NO. & & Das & & & & & & UNIT & NO. & & & - & & \\
\hline & $\begin{array}{l}- \text { LINE SHZE } \\
\text { INSUL.SPEC. }\end{array}$ & \begin{tabular}{|l|l|l|l|}
1 & $3-8-66$ & APPROVED FOR CONSTRUCTION \\
\end{tabular} & sesans & & $\begin{array}{l}\text { A.VALERO } \\
\text { Schroth }\end{array}$ & & & & SSERS & POWEF & PPLA & & on & $=$ & \\
\hline$\frac{11}{3 c 6}$ & $\frac{11}{-10 \overline{8}}$ & 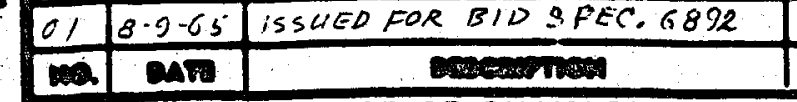 & 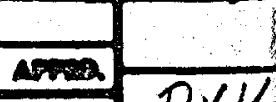 & & $5 \cdot 25-65$ & & & ce & $\ldots$ & & AVE & & & 1 & \\
\hline & & TAN of Craters & DVK & & NONE & & & & $\operatorname{anc}$ & & & & 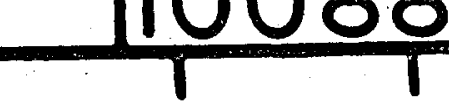 & & \\
\hline
\end{tabular}




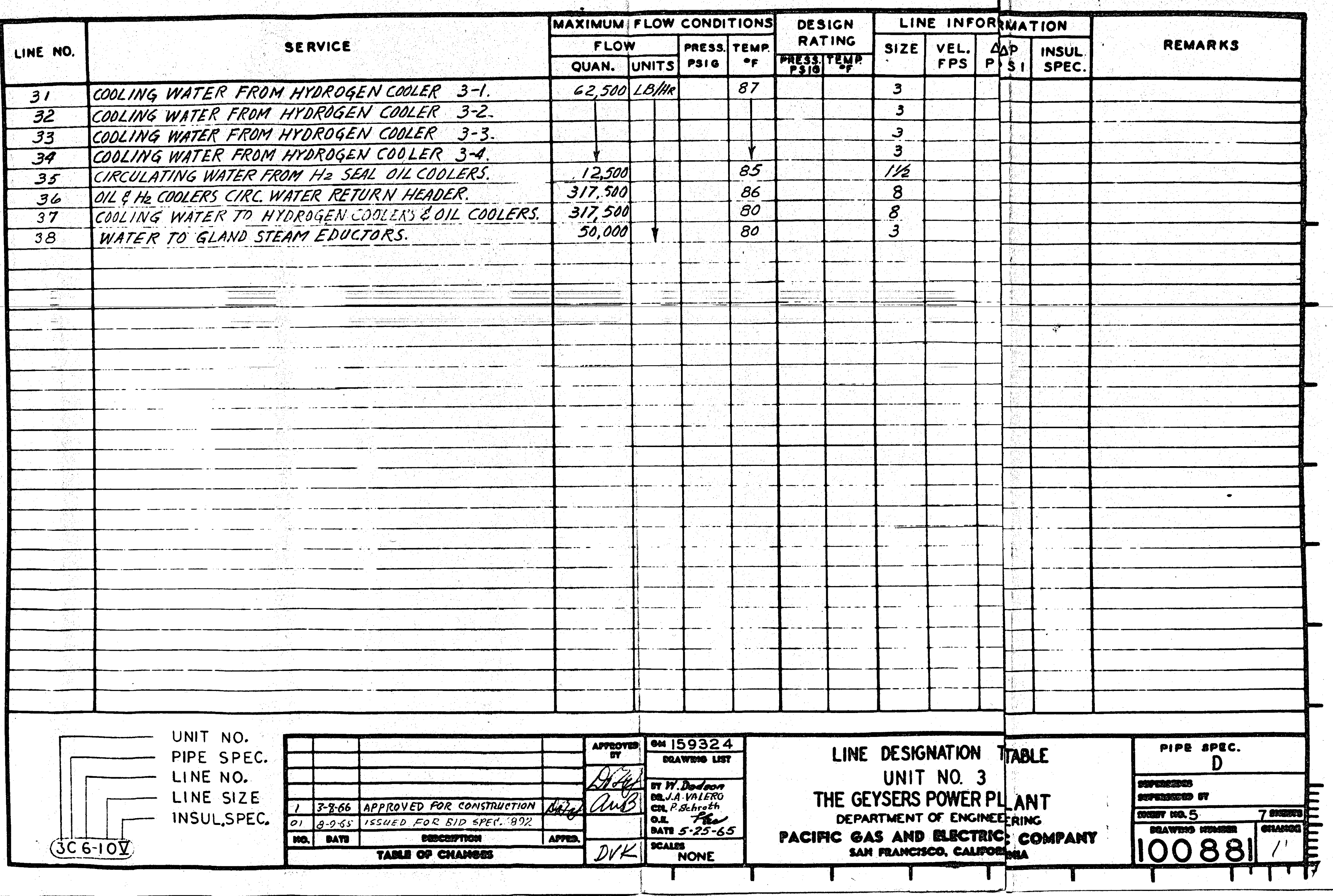




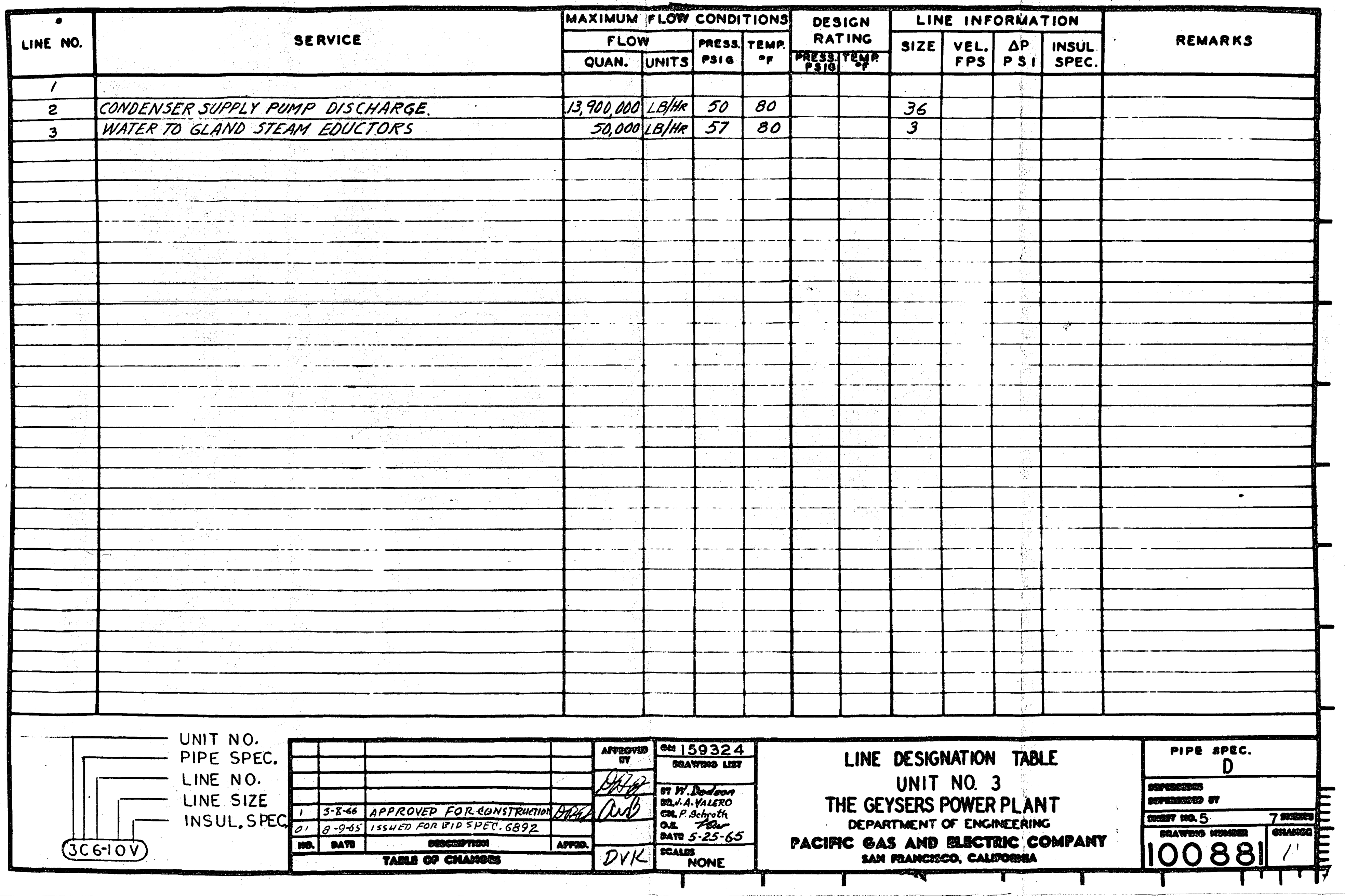




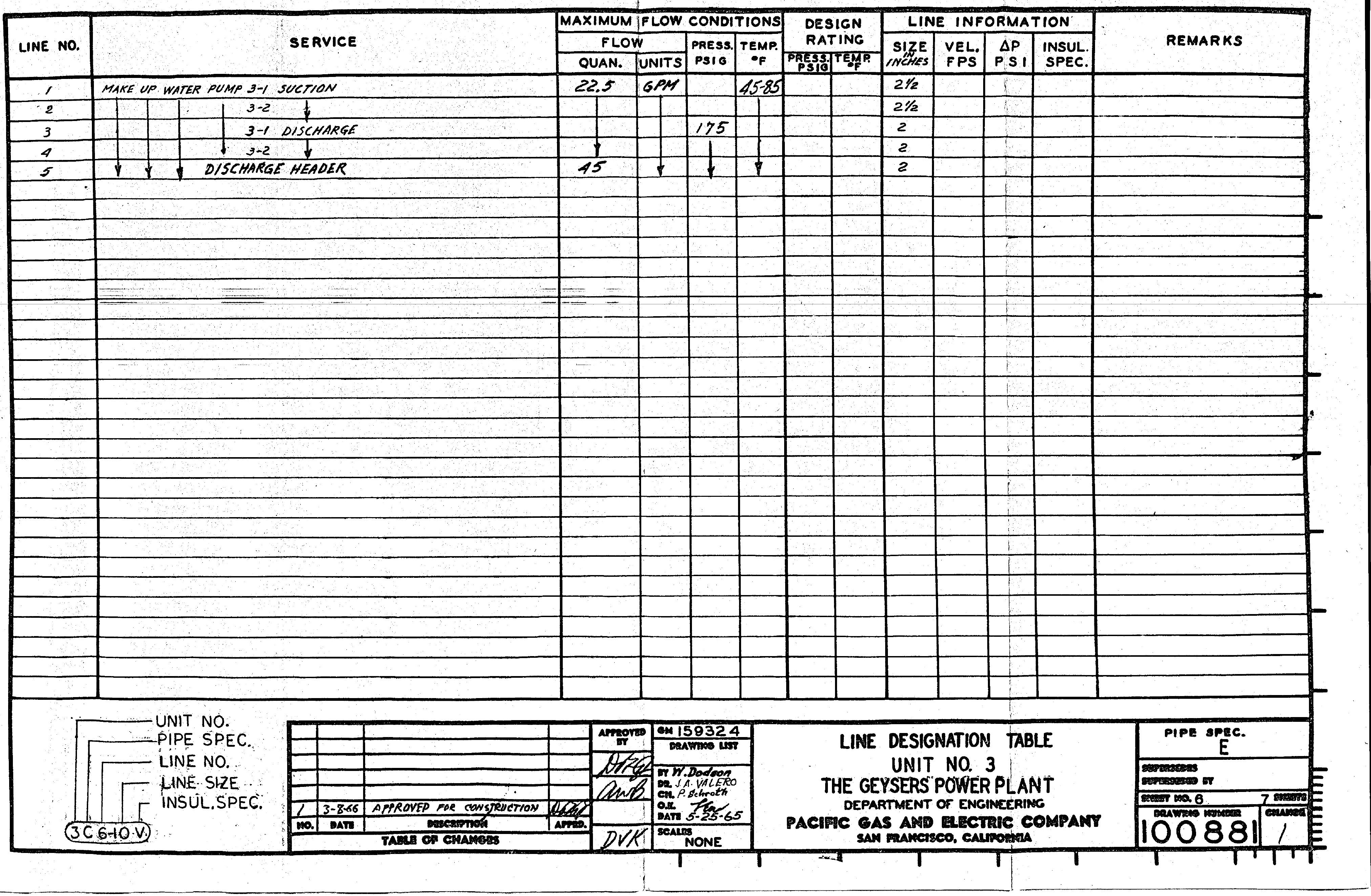




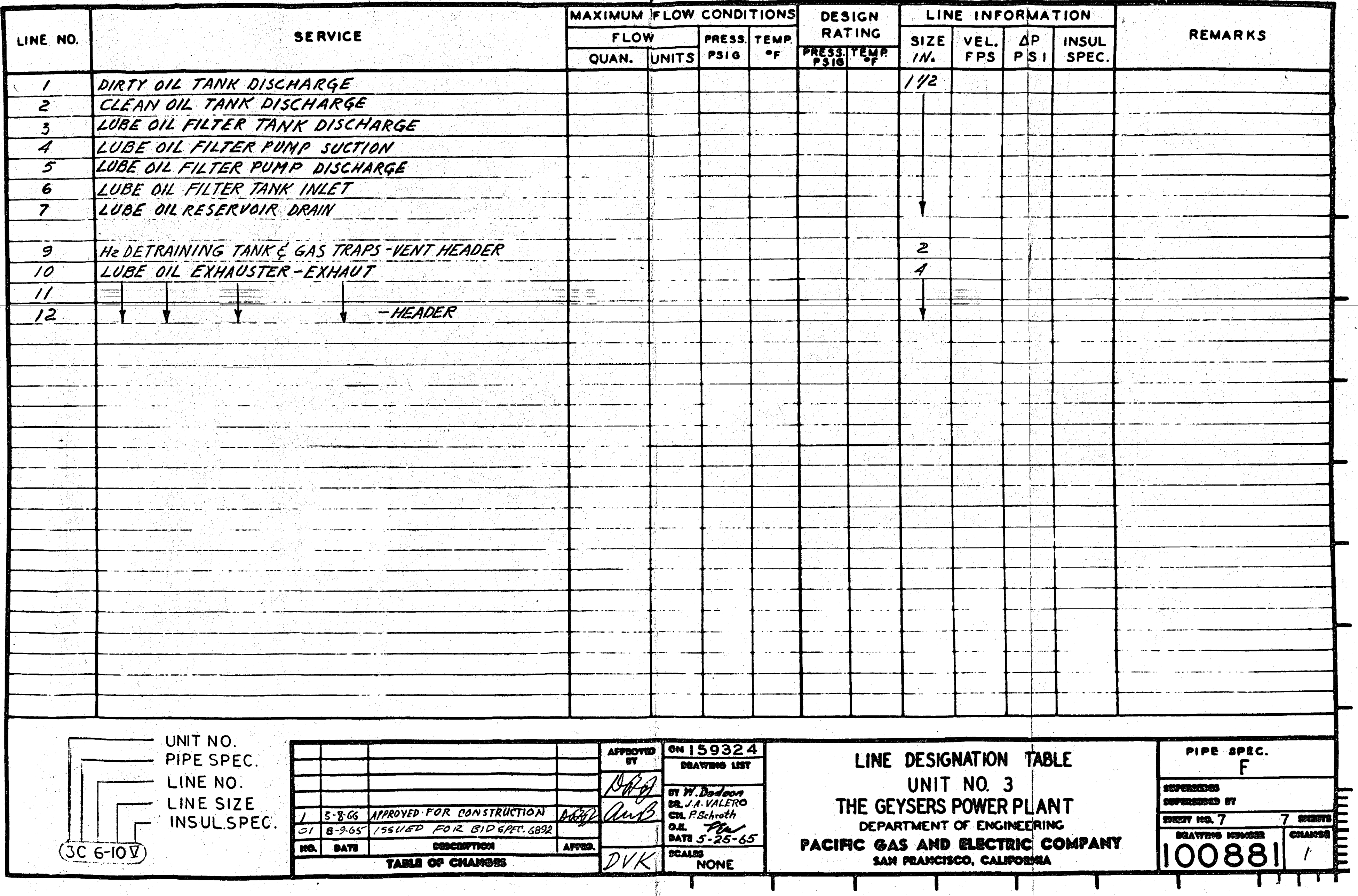




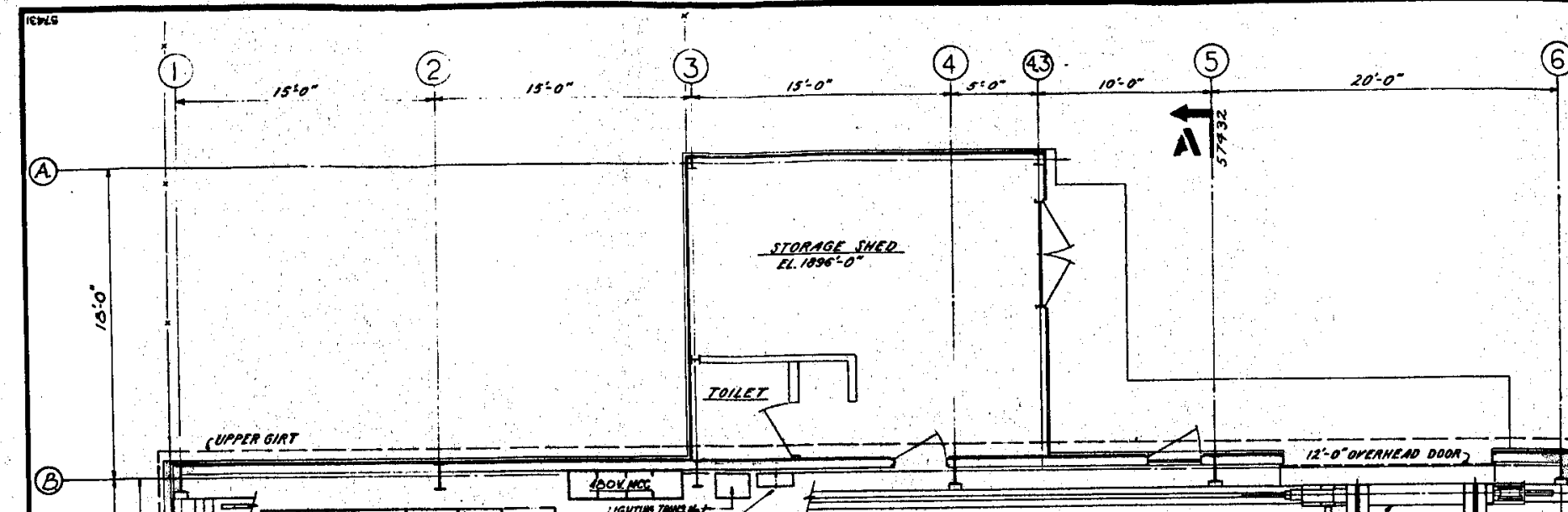

(6) me

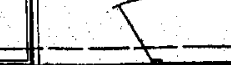
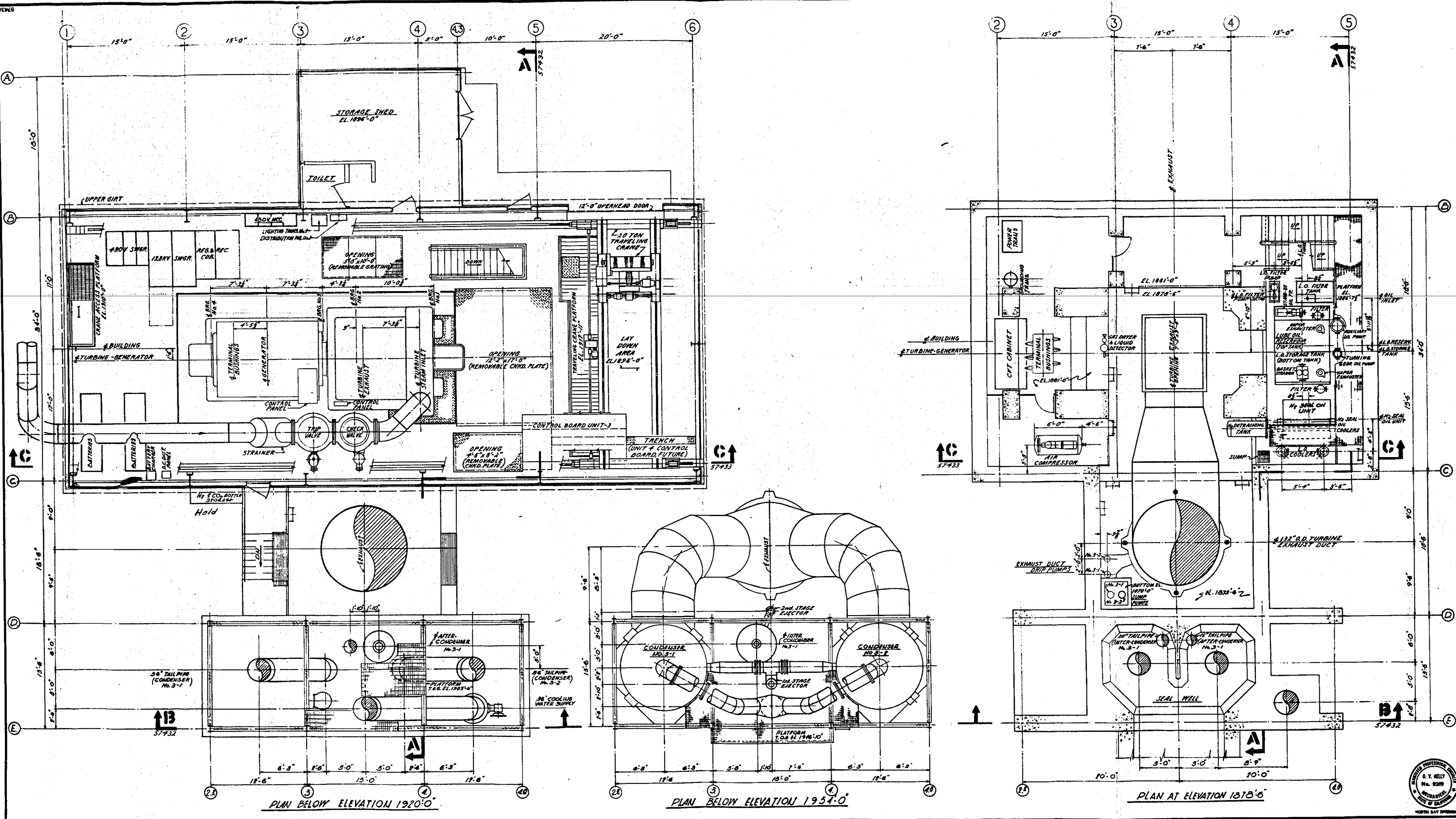

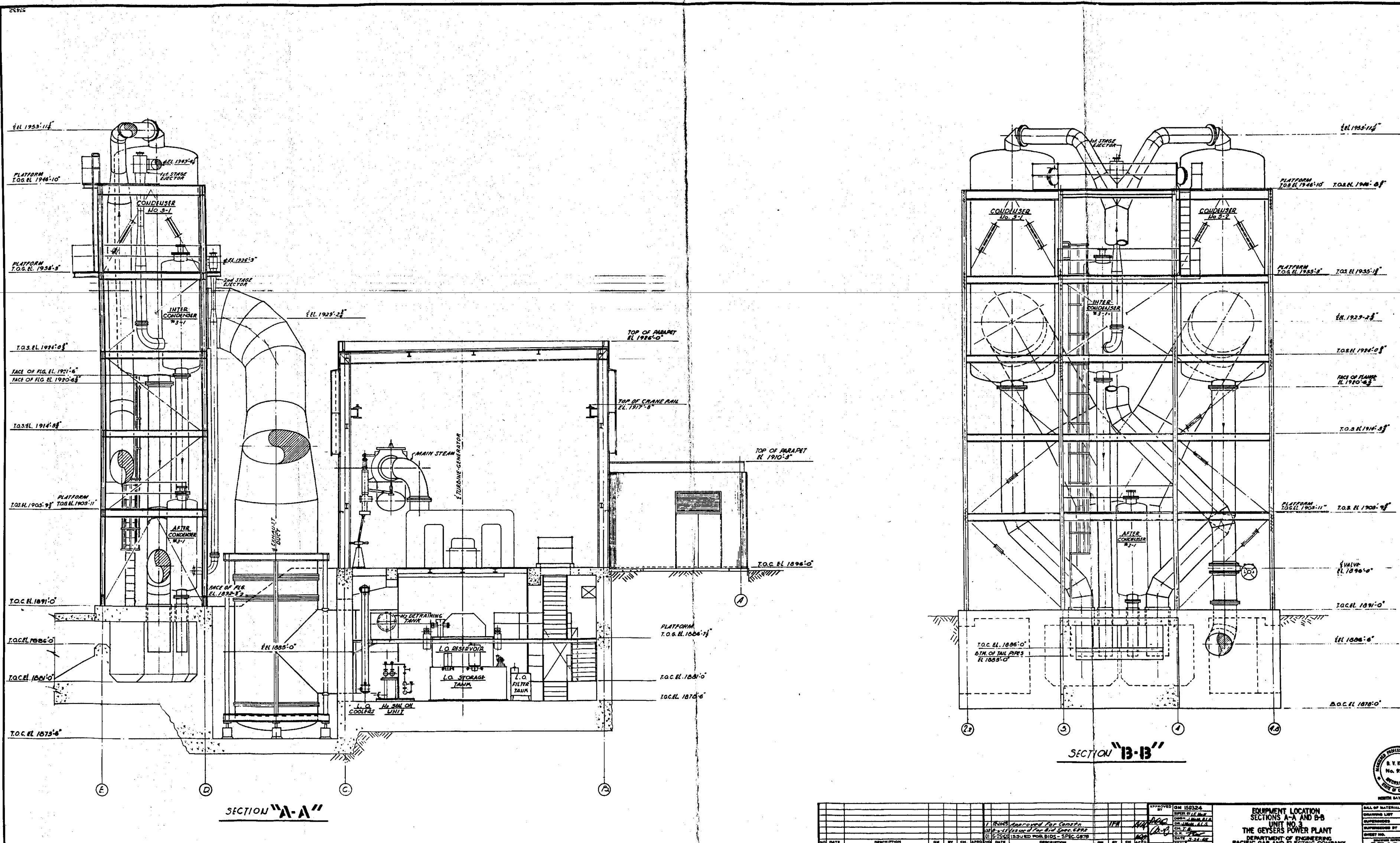

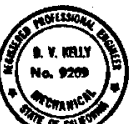

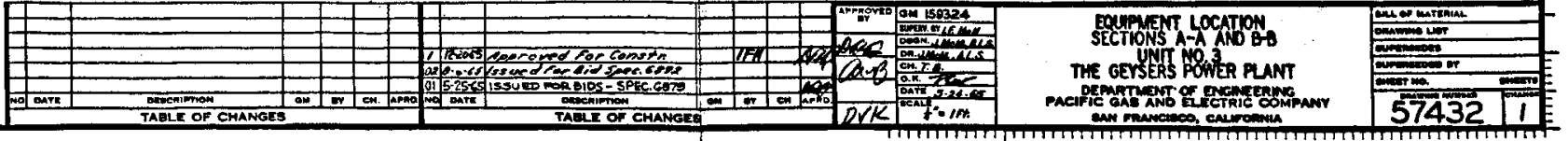






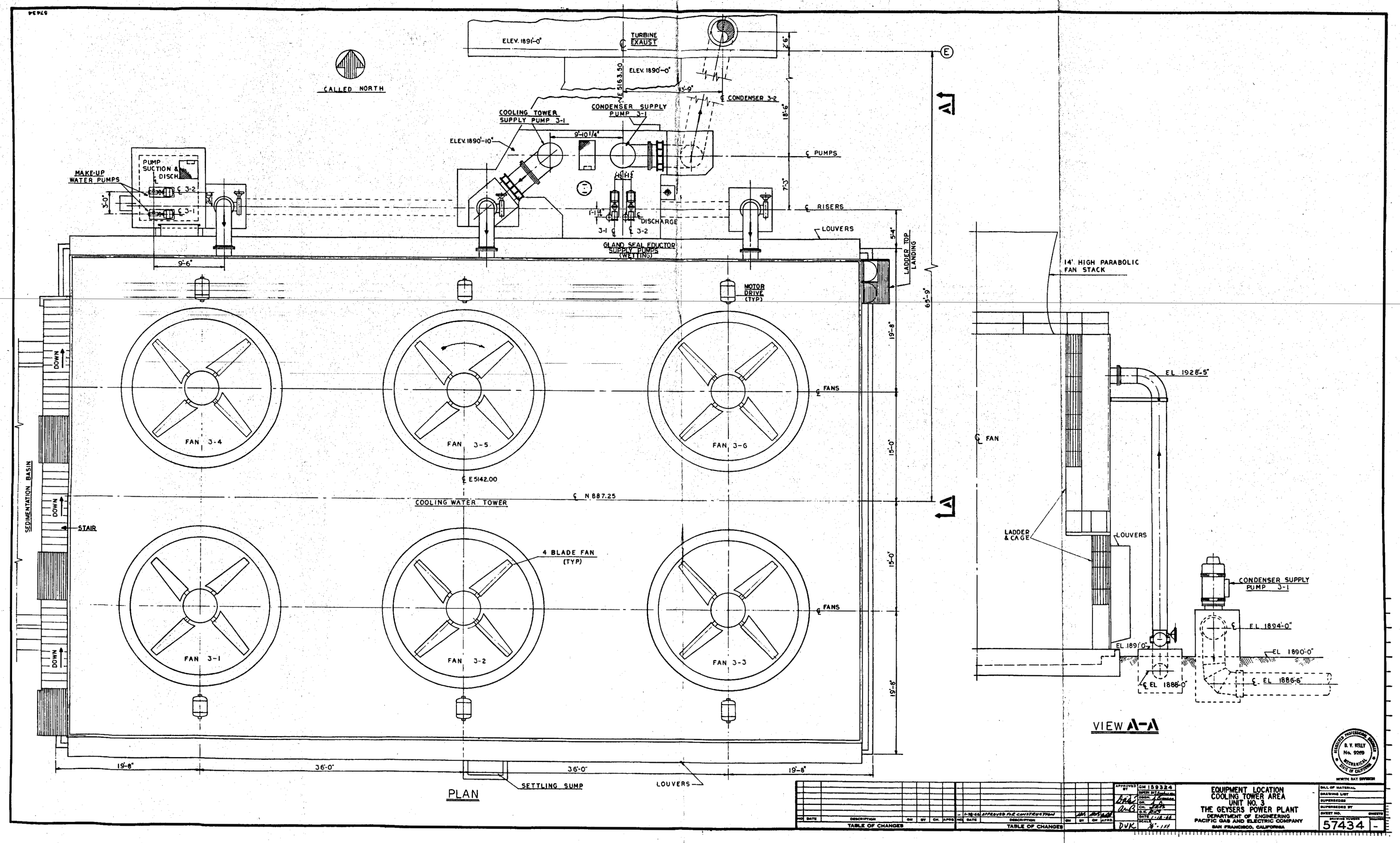



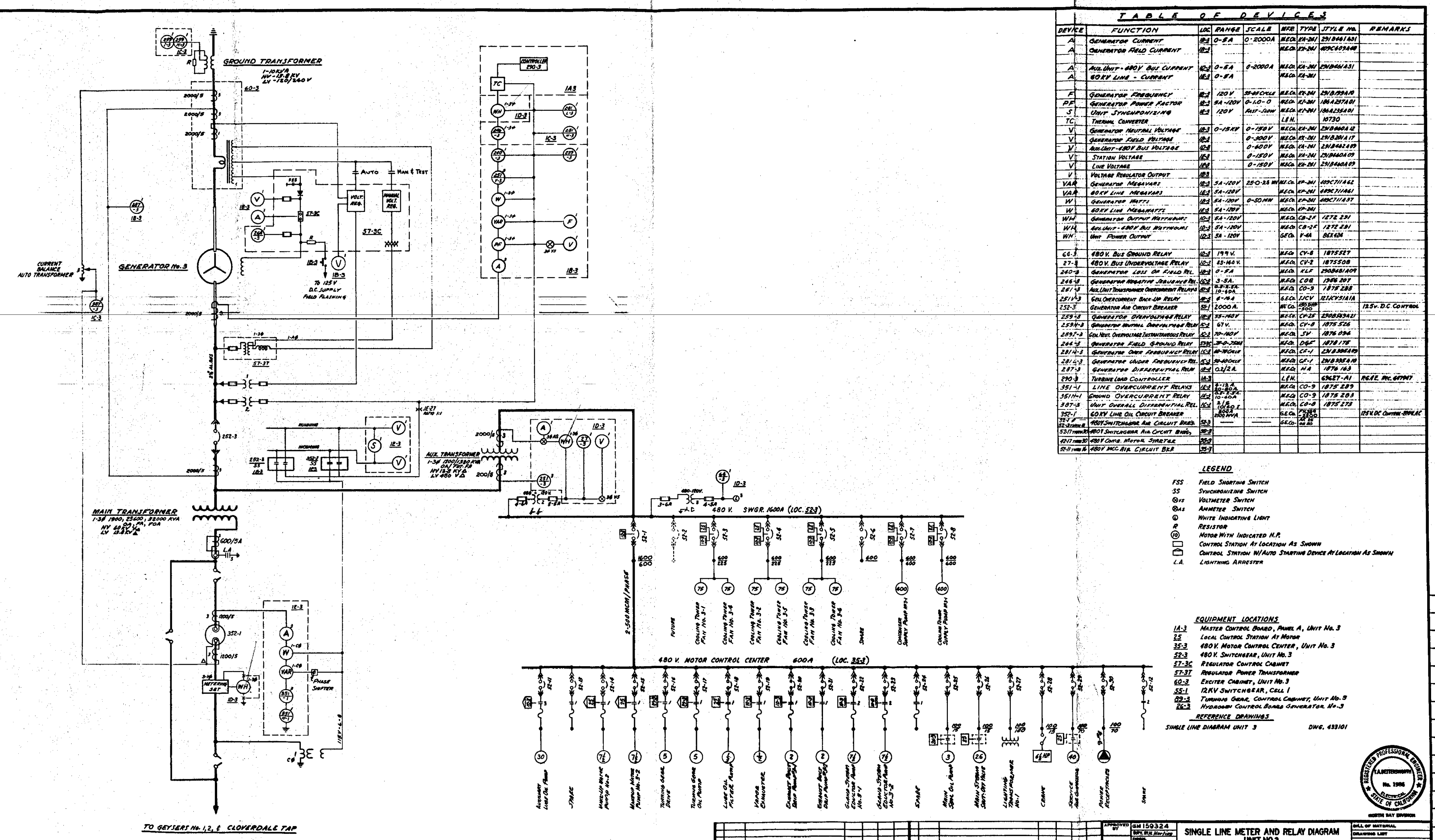

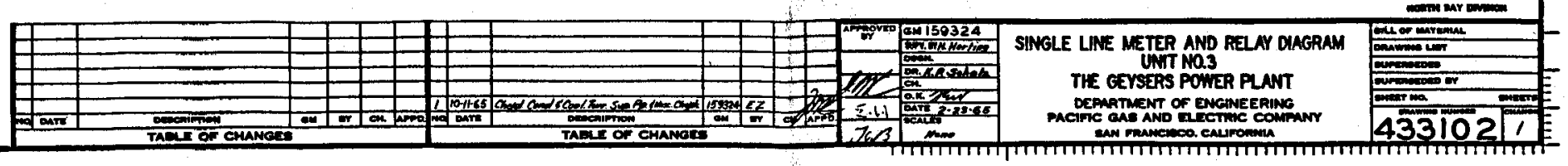



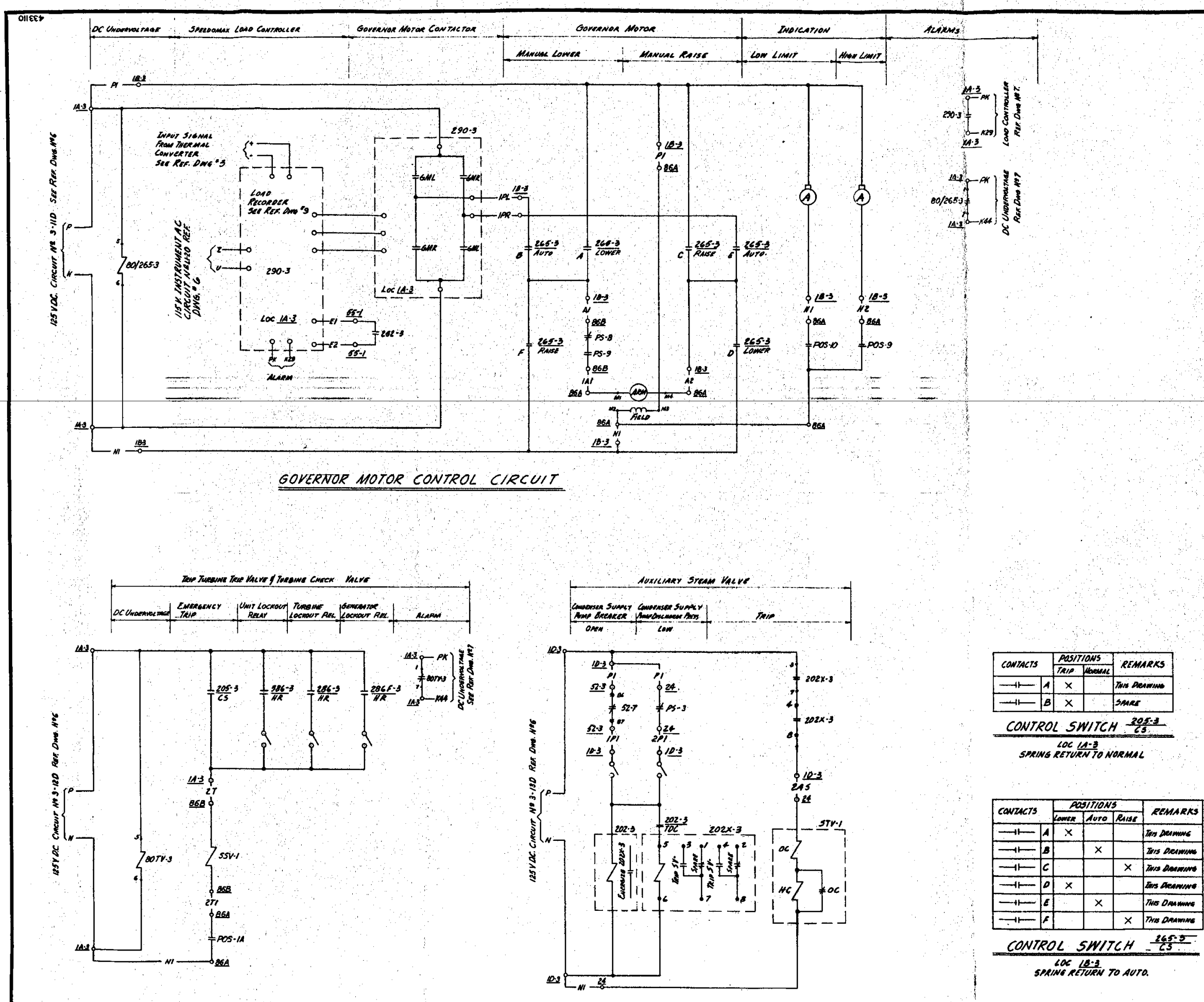

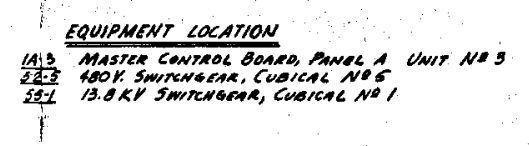

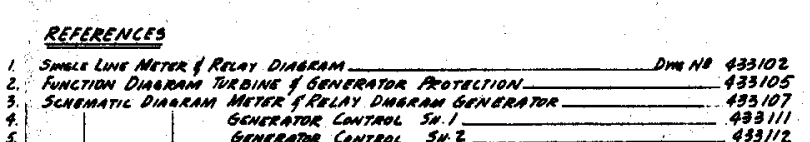

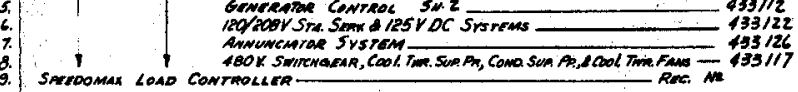



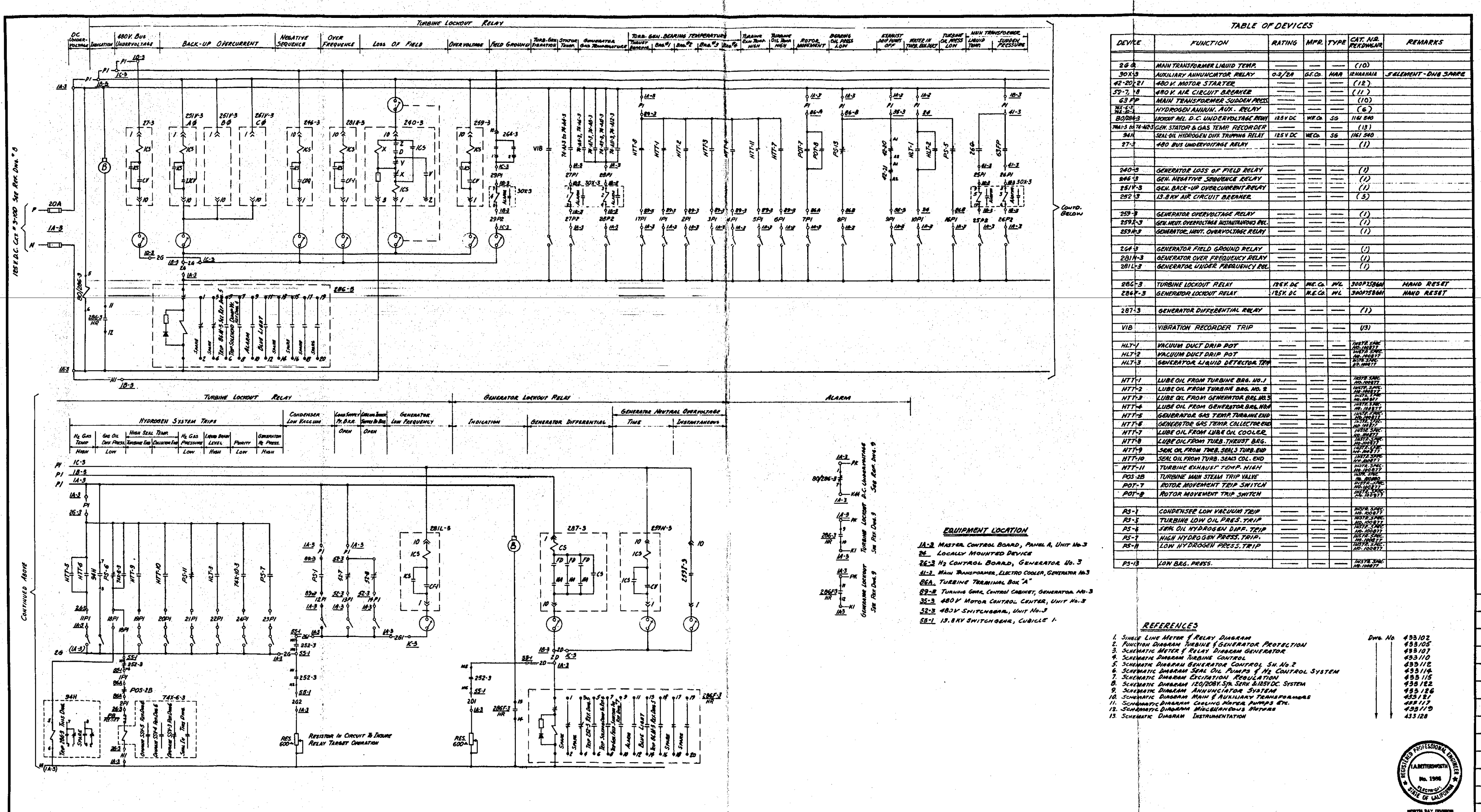


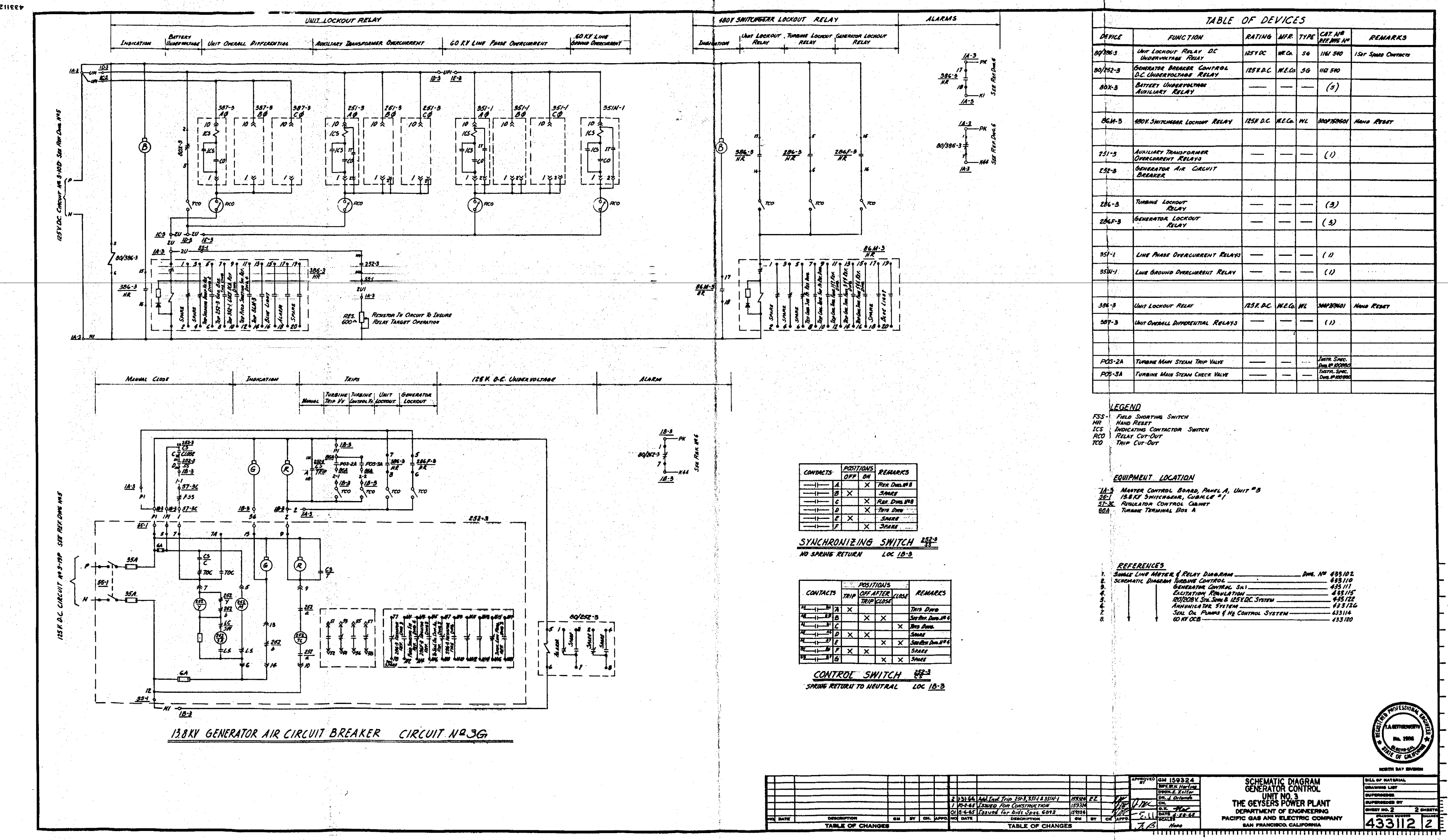



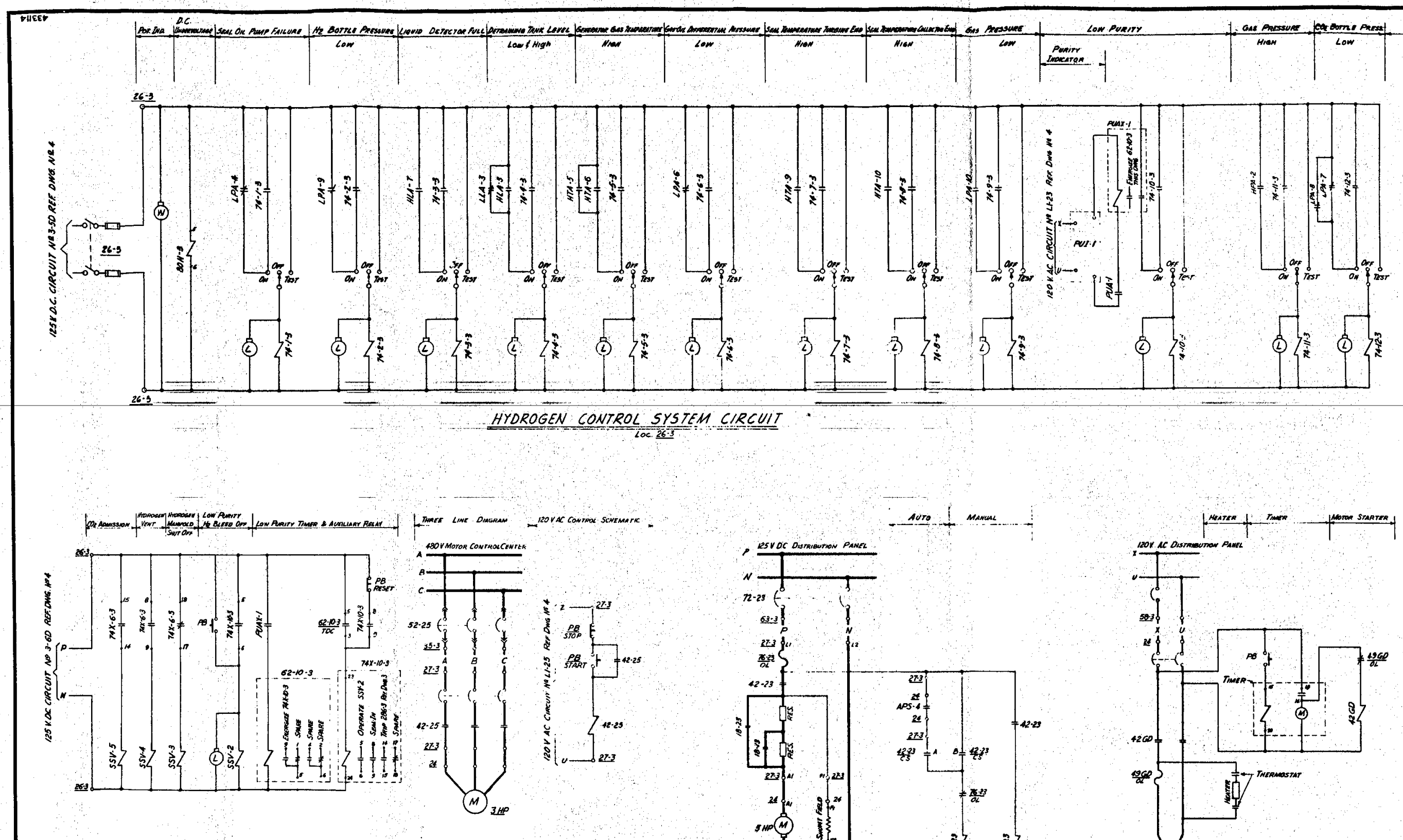

ATOROGEN \& CO B MANFOLO VALUES

MAIN SEAL OL PLMP CRRCUT NQ $3 P 25$

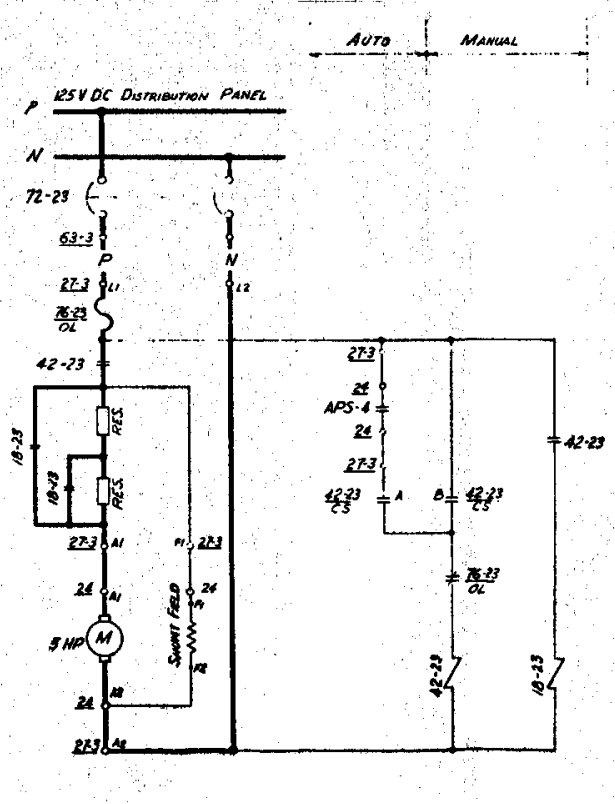

STANDEY SEAL QIL PUMP CIRCUIT NE 3 ITTD

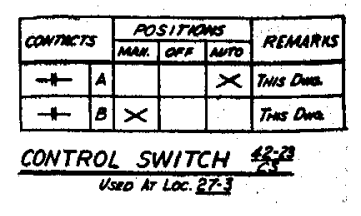

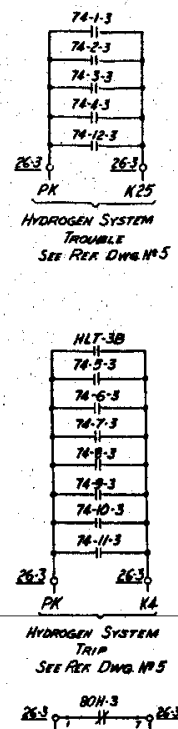

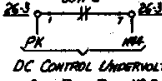

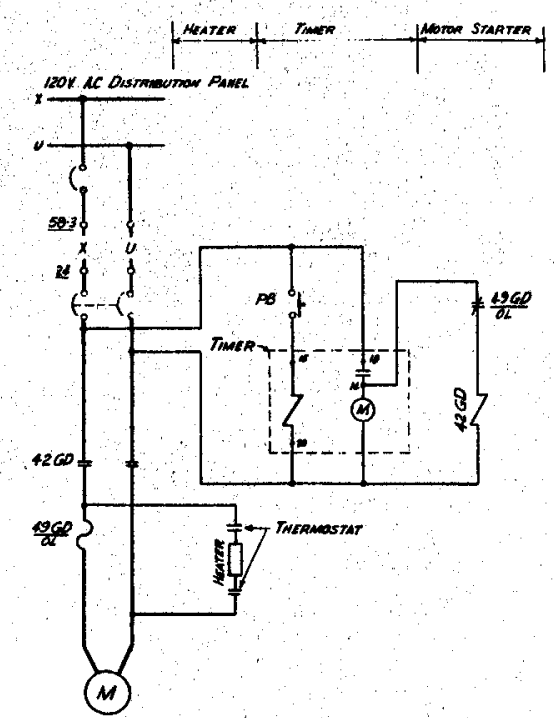

GAS DRYER CIRCUIT NOLL.18

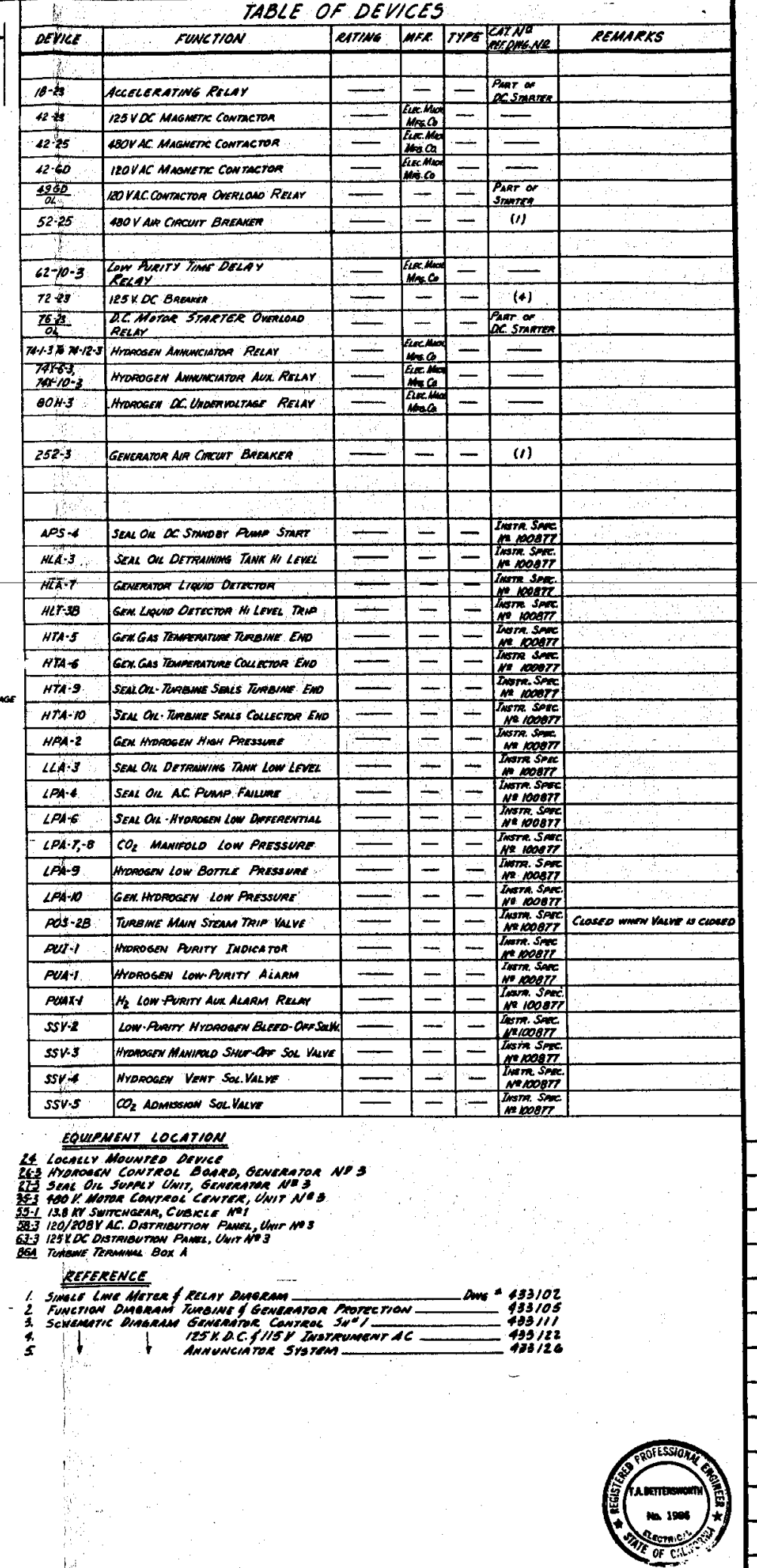




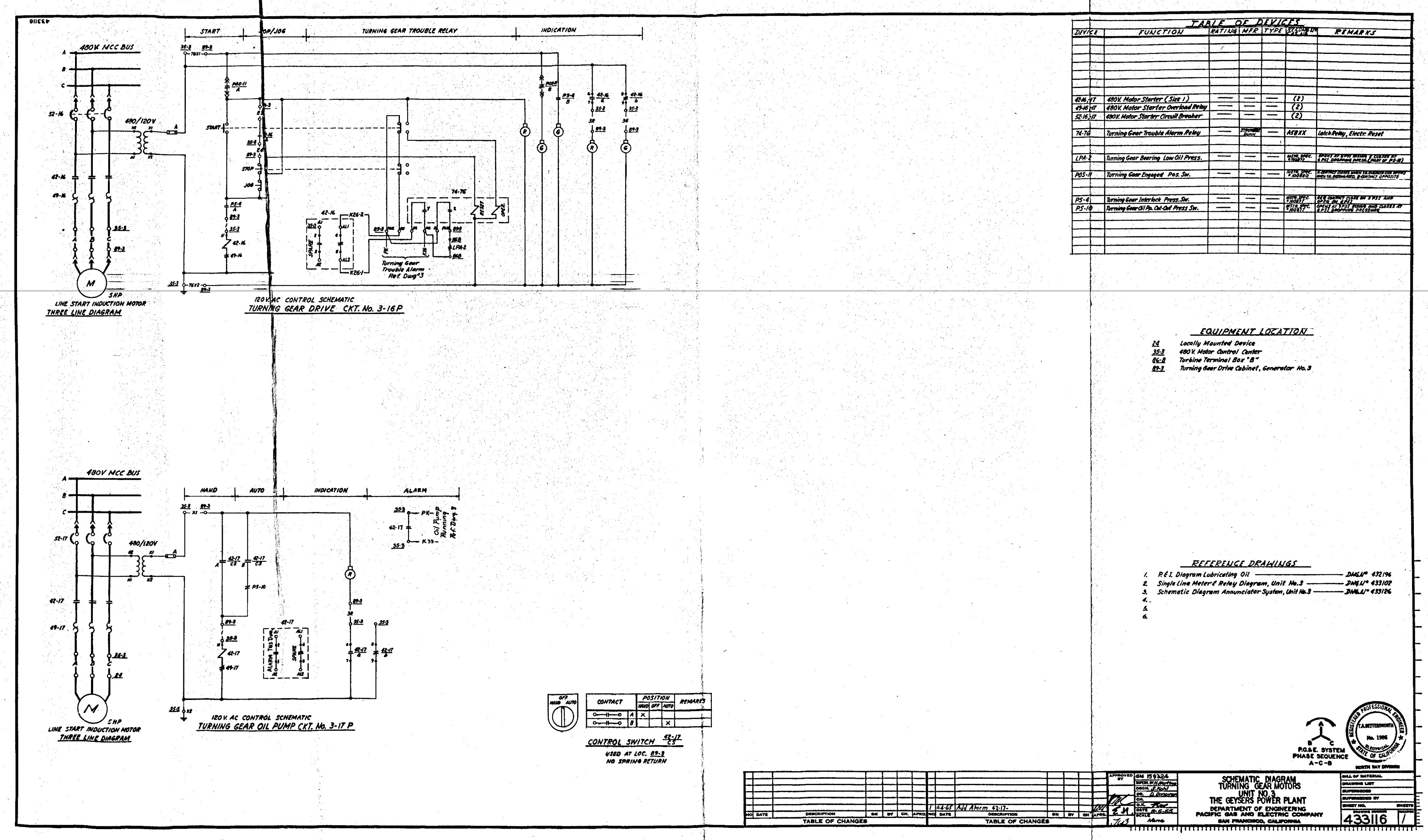




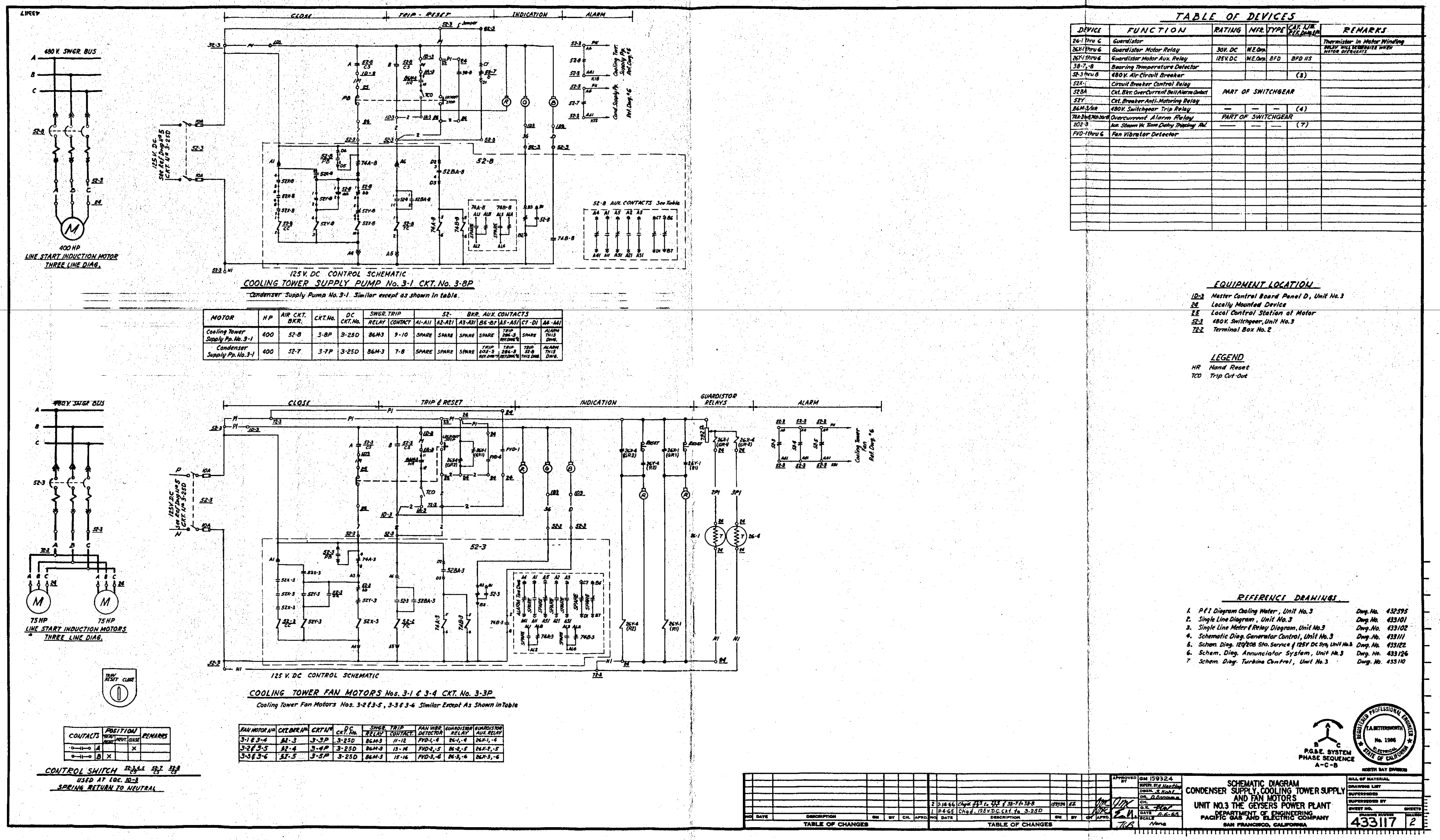




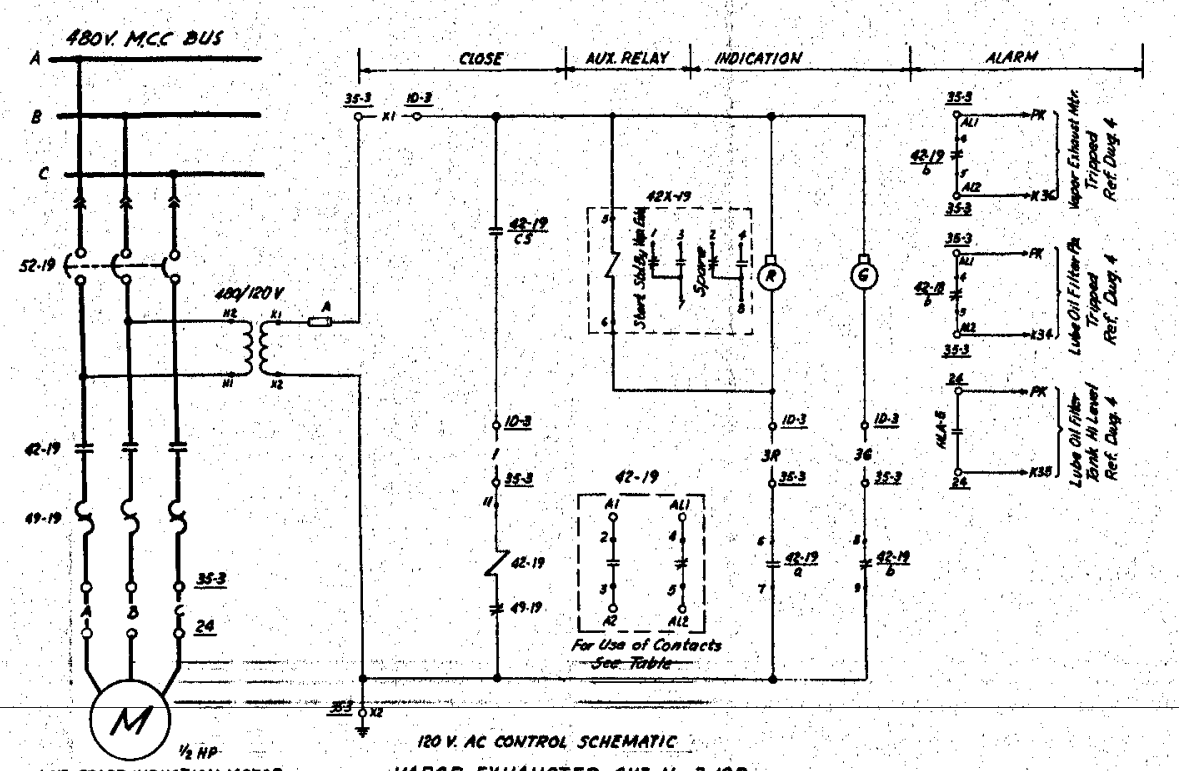

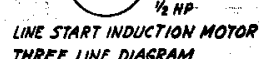
VAPOR EXXAUSTER CXT. Na.3.19R

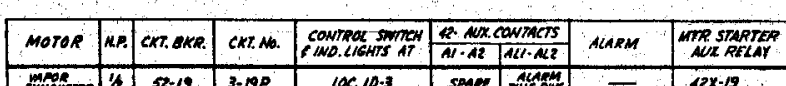

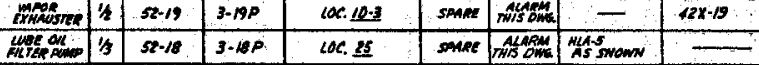

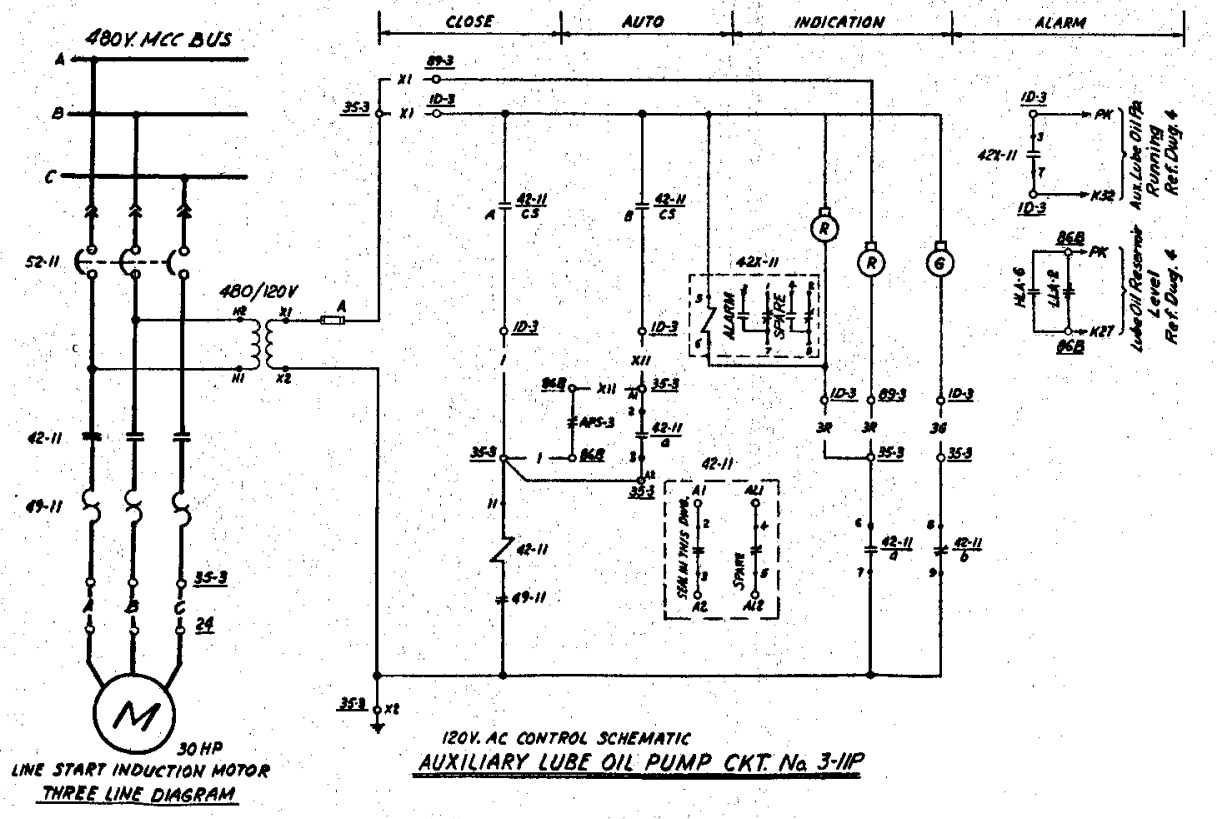

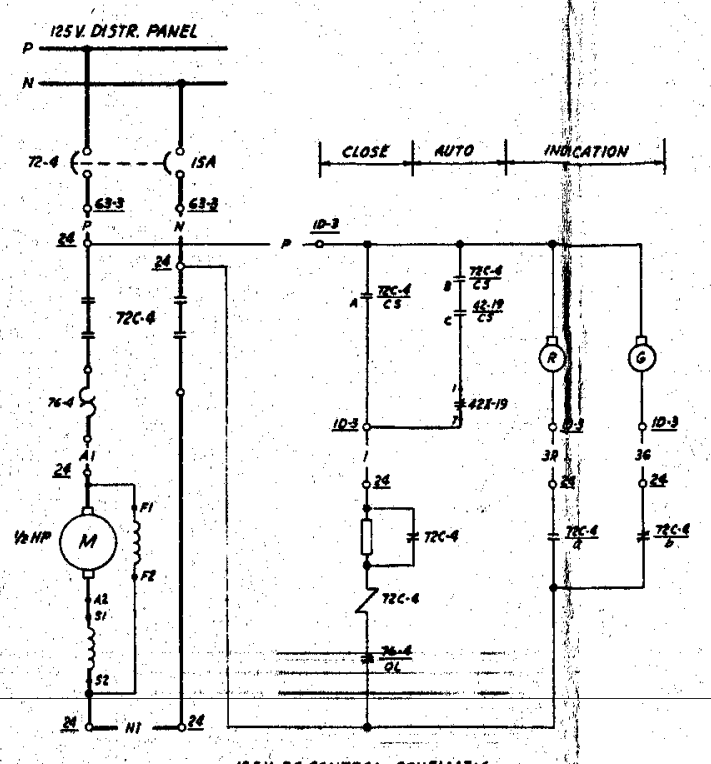

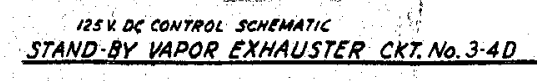

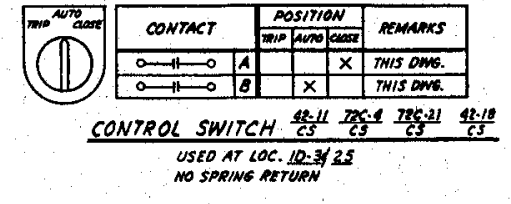

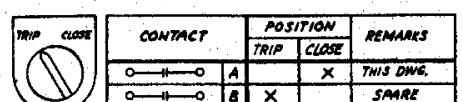

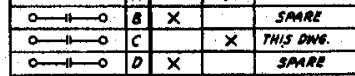

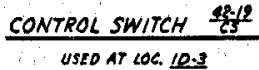

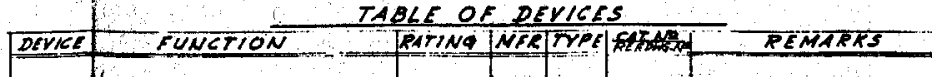

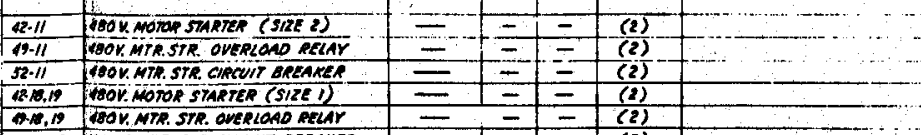

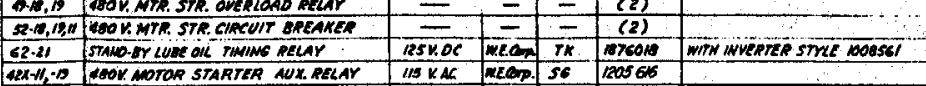

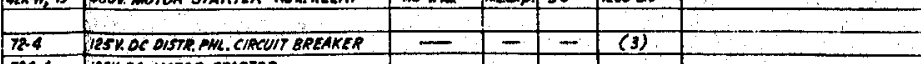

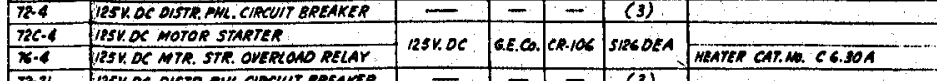
Trest

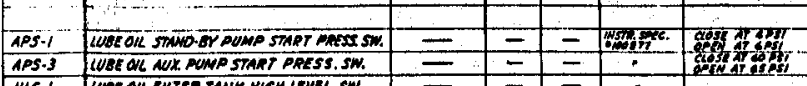
atis

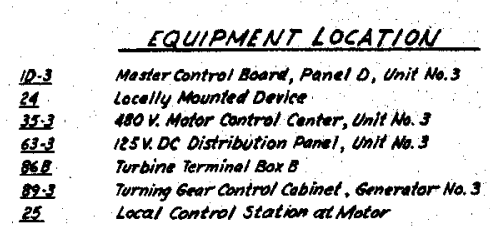

REEERECE DeAWINGS

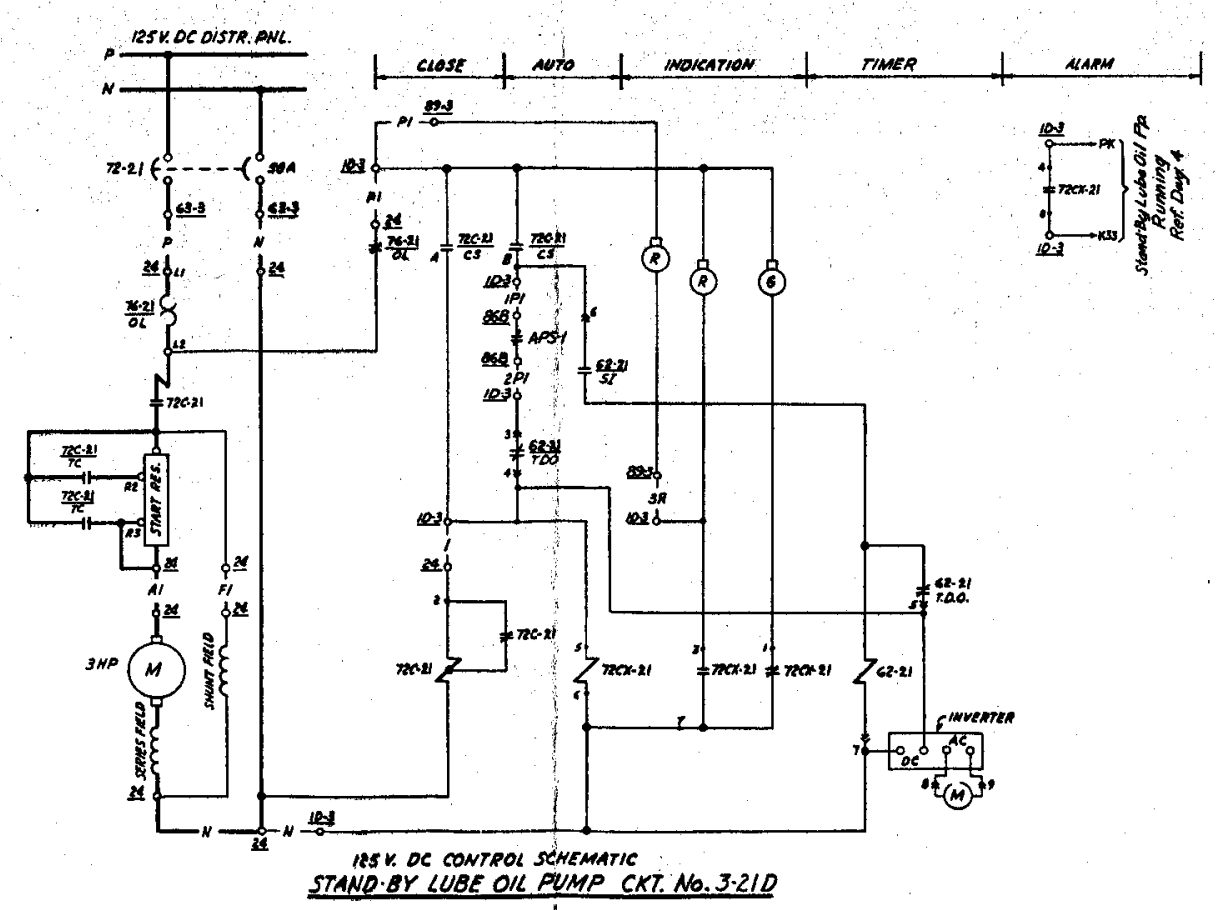

ReEERENCE DeAn

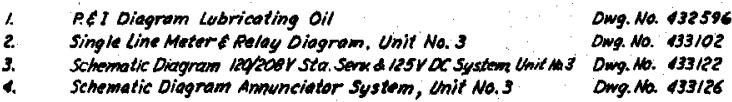

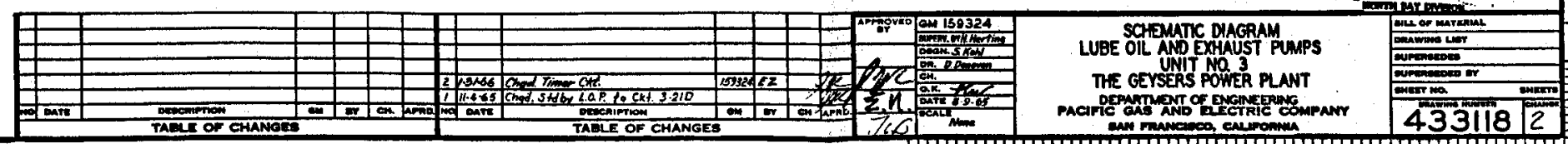




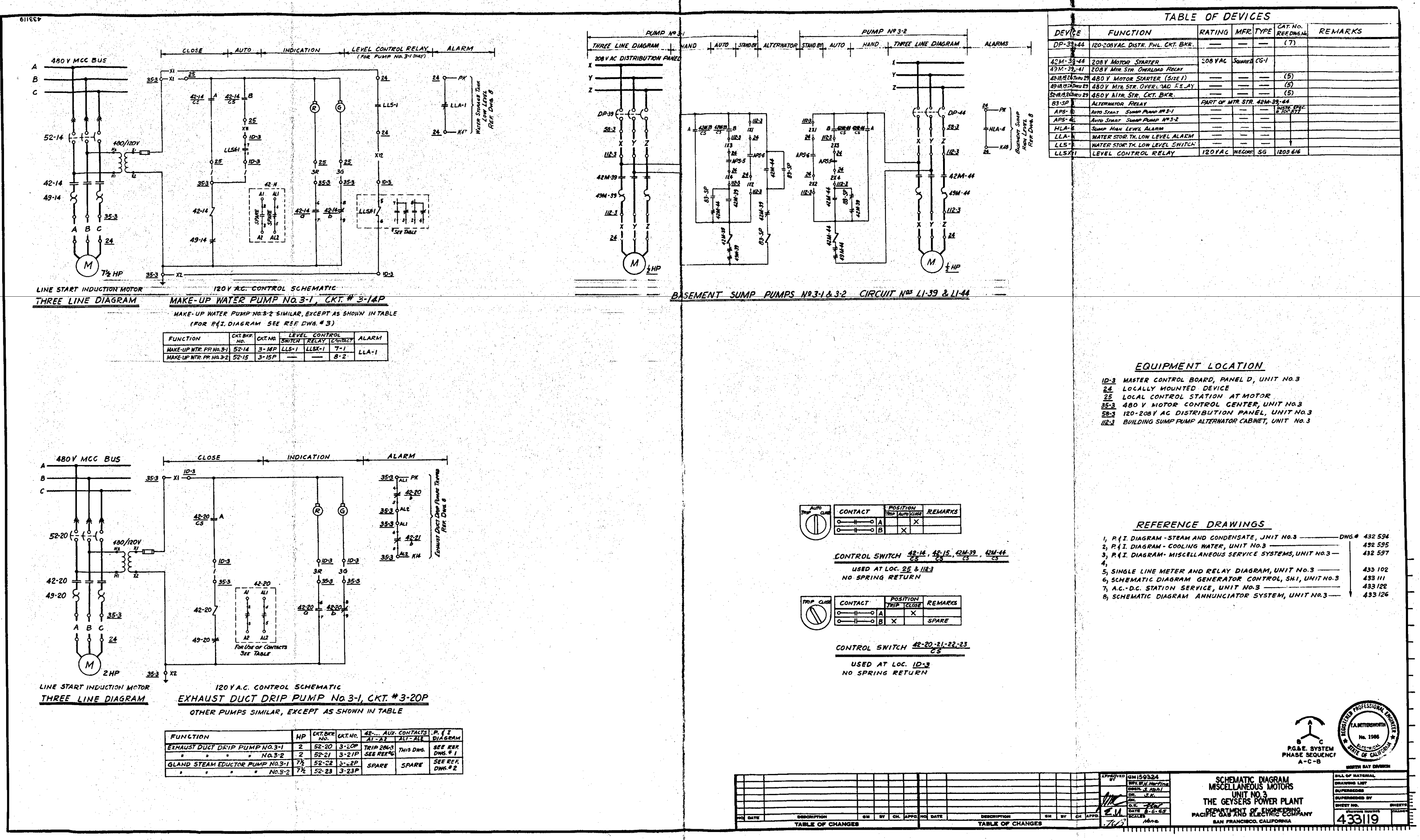


C.

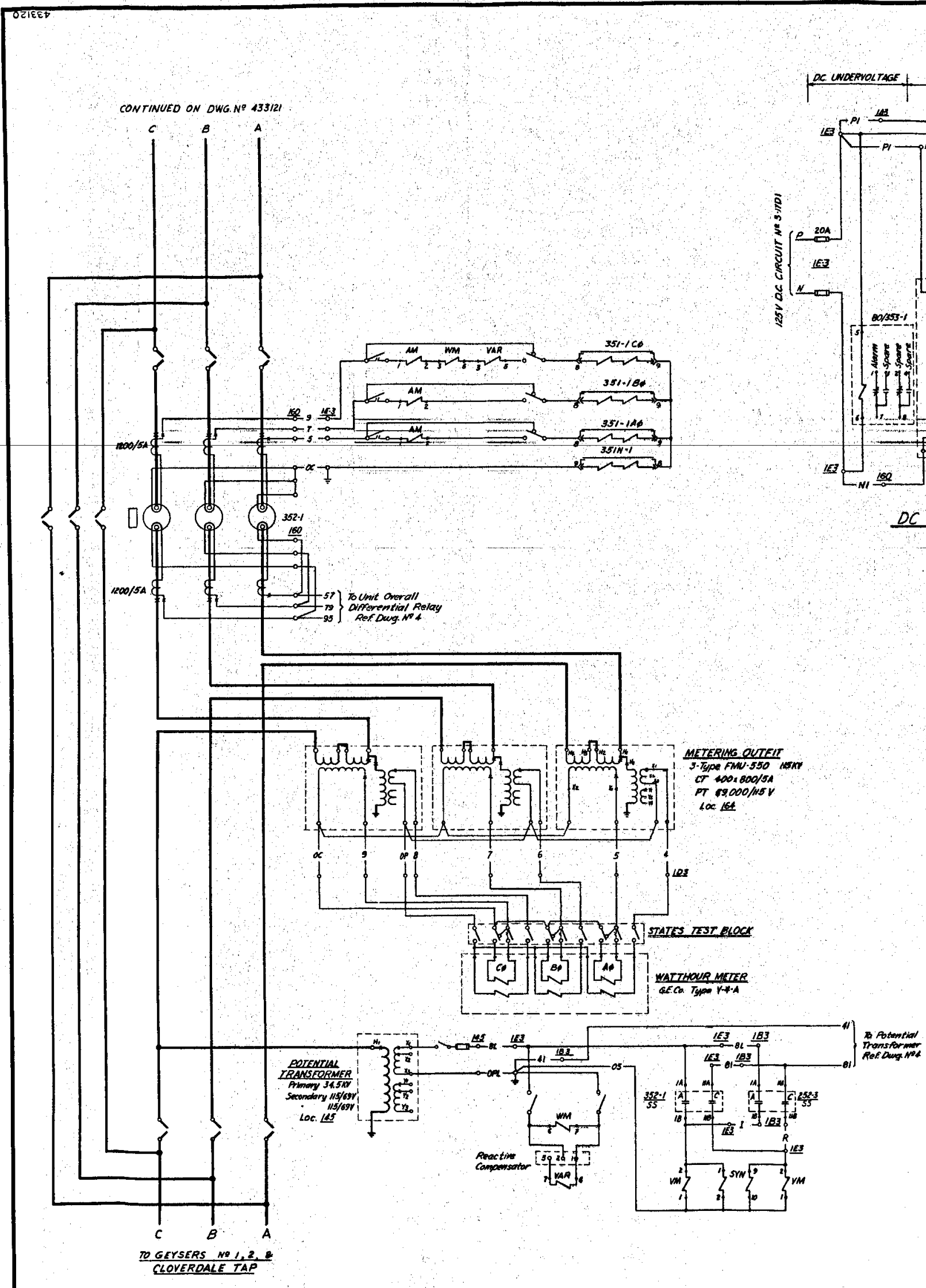

TABLE OF DEVICES

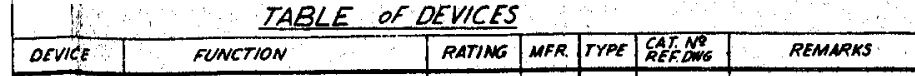

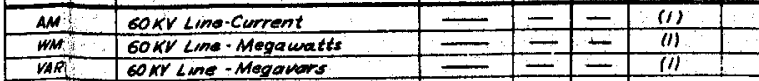

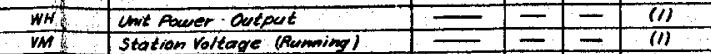
$=1= \pm$ +

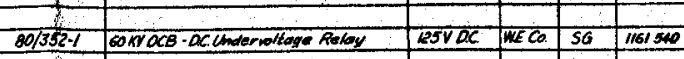

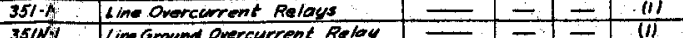

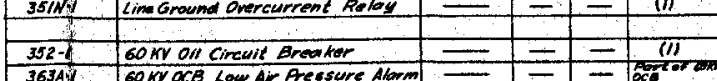

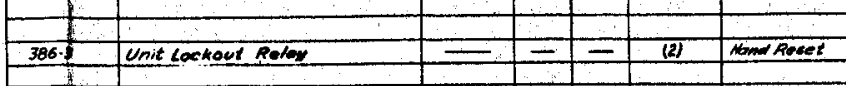

GQUIPMENT LOCATION

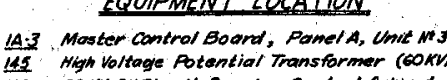

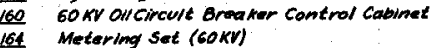

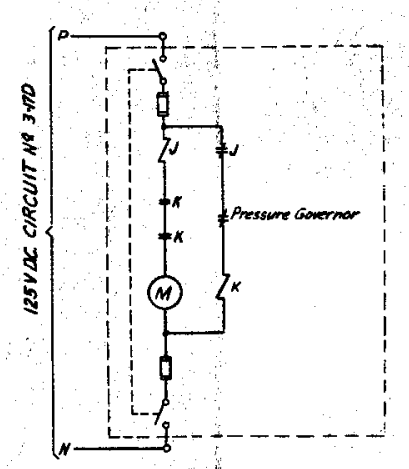

COMPRESSOR MOTOR CIRCUIT.NO 3-9D

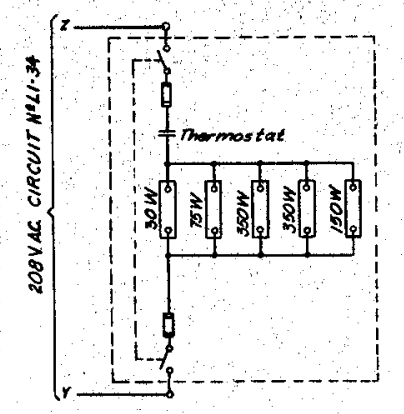

CONTROL MECHANISM HEATER CIRCUIT NOL-3L

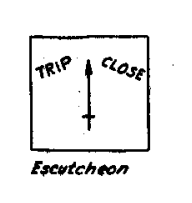

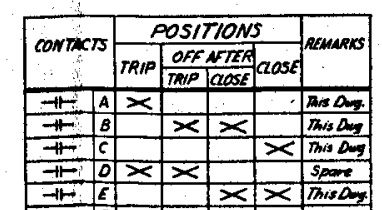

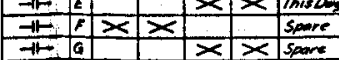
$\frac{\text { CONTROL SWITCH CS }}{\text { SOSTES }}$

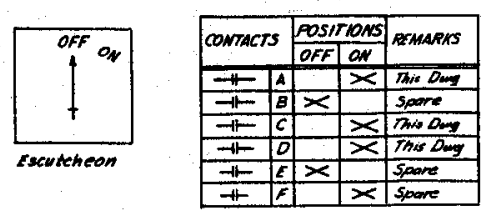
SYNCHRONIZING SWITCH $\frac{\text { 3FF"- }}{35}$

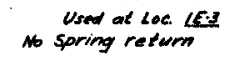

REFERENCES

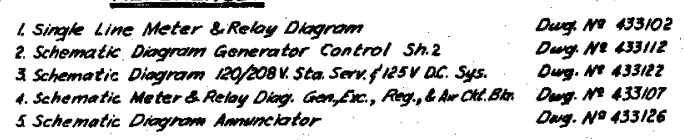




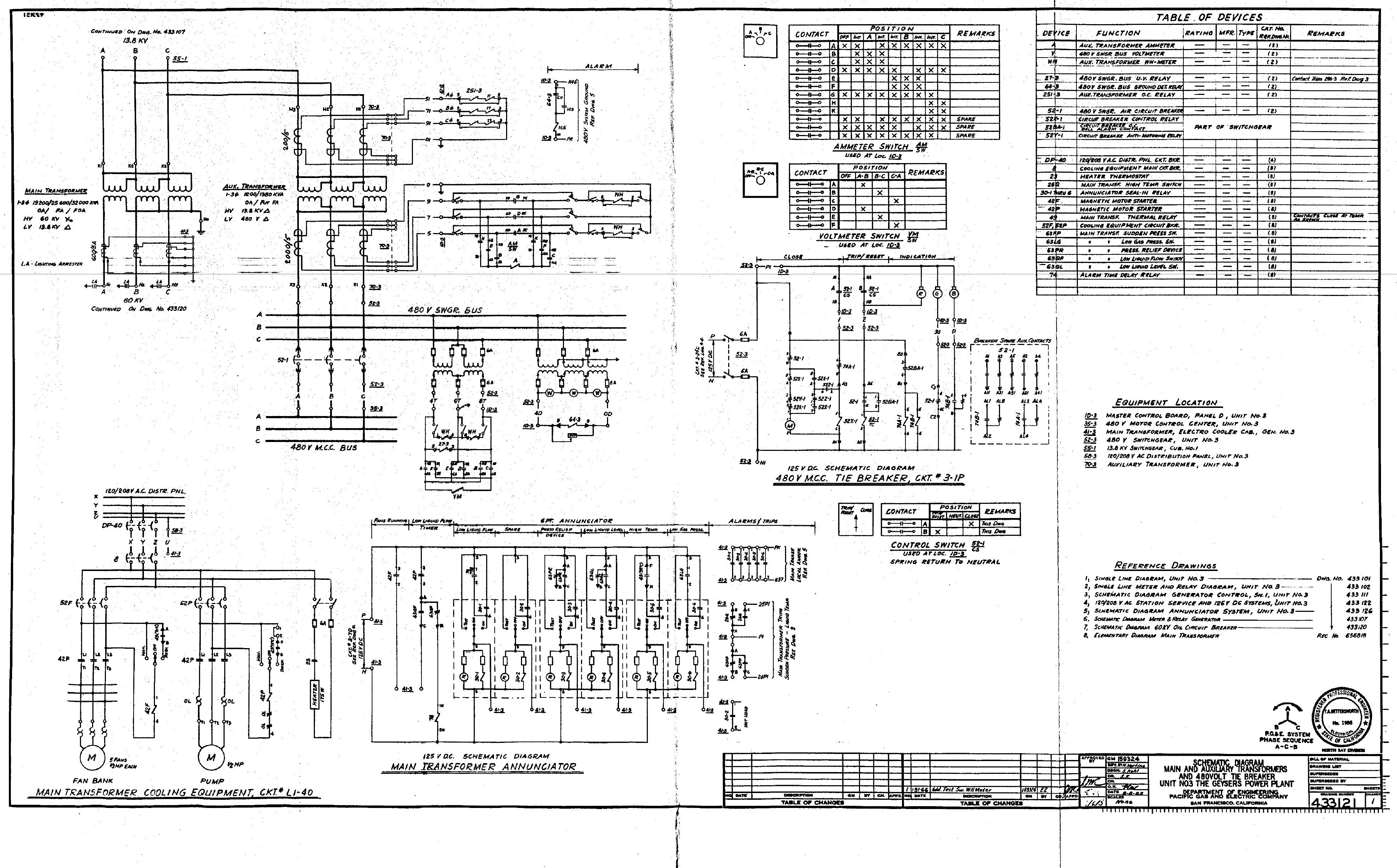




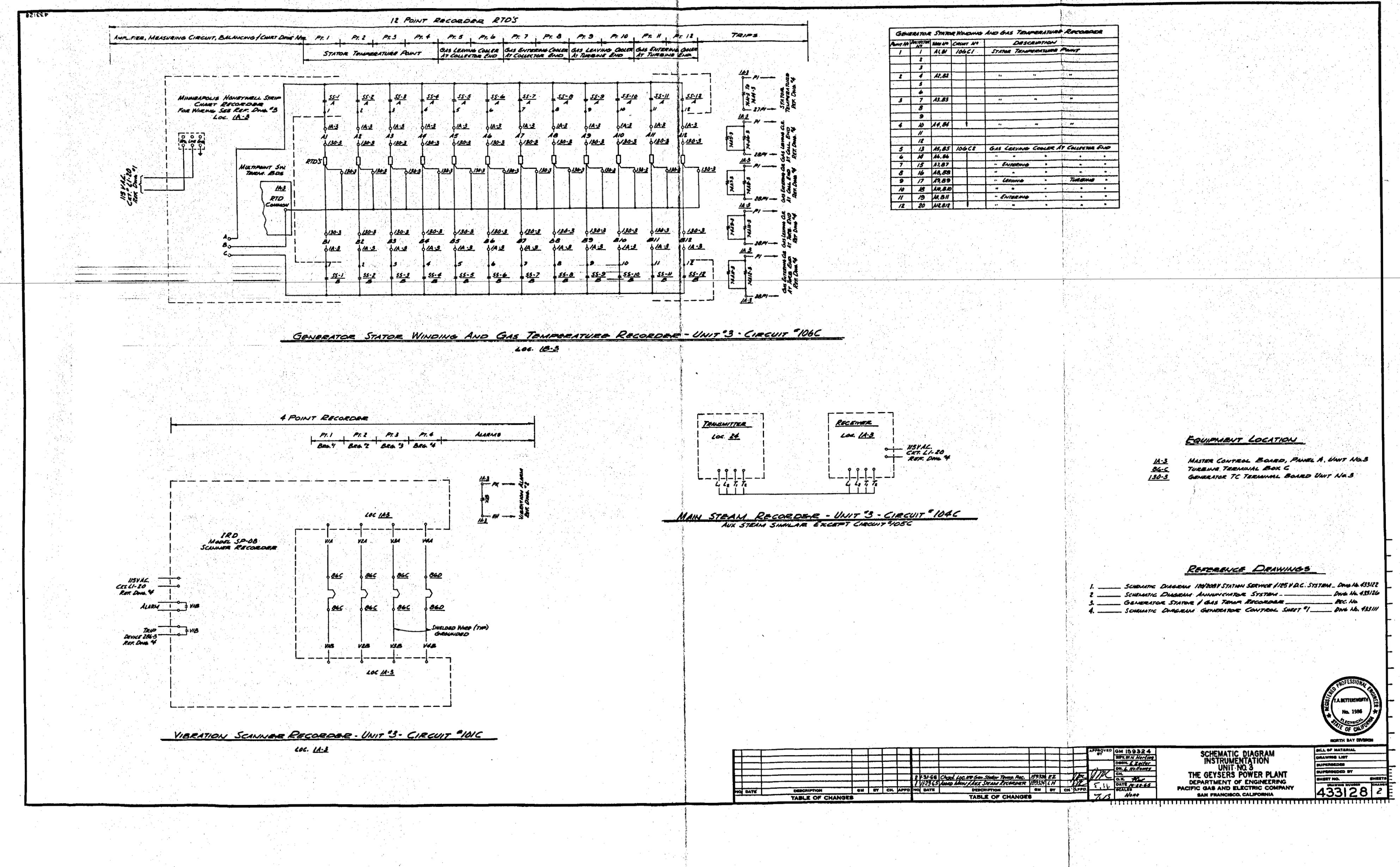

